示- 1 胃癌症例における HLA-DR，TIL と臨床 病理学的各因子の関連

関西医科大学第 2 外科, 中㭘病理 *

岡村成雄, 田中完児, 中根恭司, 奥村俊一郎, 明平圭 司, 朴常秀, 大草世雄, 岡村明治*, 日置紜士郎 【はしめに】周癌症例を対象に，腫痛の局所免疫能を 反映するとされる HLA-DRの発現と腫㷰内浸潤リンパ 球 (TIL), 各種臨床病理学的因子との関係につき検討 した。また胃癌㾐の中ても特に予後の要いとされる 肝転移症例についても検討を加えた。

【材料・方法】過去 10 年間に当科にて切除された原 発性胃症症例のうち術前化学療法, 放射線痖法等の治 㾣の行われていない162例（手術時肝転移陽性症例 29 例を含む)を対象とした。標本は $10 \%$ ホルマリン固 定しパラフィン包埋後 $3 \mu \mathrm{m}$ に薄切し，磷素抗体間 接法を用いHLA-DR およびTILの免疫染色を行った。 一次抗体として HLA-DR は LN-3(Histoclone 社) を, TIL はUCHL-1(Dako 社)を用いた。 HLA-DR は陽性腫瘦細 胞数に応しその Grade を G I :10\%以下,G II :10-50\%,G III :50-80\%,G IV :80\%以上に分類し,TIL数は腫瘦内間賈 (IS), 腫㾇先進部内 (IF) の $0.16 \mathrm{~mm}^{2}(400 \mu \mathrm{m} \times 400 \mu \mathrm{m})$ あ たりの陽性細胞数を算定した。

【結果】HLA-DR陽性細胞は全例に瑟められた。 HLA-DR は stage が進むにつれ G I が多く G N が少な くなり，この傾向は肝転移症例で最も顥著であった． TIL 数は HLA-DRの Gradeが高くなるにつれ増加し， また IFの方が ISより高かった，HLA-DRの表出程度 と深達度, $1 \mathrm{y}$ 因子, $\mathrm{v}$ 因子等各種臨床病理学的因子 との間には密接な関係が認められた。また組織型別に 見ると HLA-DRは分化型胃癌において表出率が高い症 例が多かった。予後は HLA-DRの表出事が高い症例ほ と速隔成績が侵れていた。手術時肝転移例と非肝転移 例 (stage $\mathrm{N}$ ) との比較では，肝転移例は HLA-DRの発 現事か低い症例か多く，特に分化型癌て HLA-DRの表 出率が低い应例か多かった. TIL数も同 Grade 間の比 較で少なかった。予後を見ると手術時肝転移例での 5 年生存例は HLA-DR が G N の一例のみであった。次 に対象症例のうち再発を来した症例を検討すると肝転 移再発例は腹膜再発例に比較して G I が多く, TIL 数 も少なかった。組織型別に見ると分化型癌で HLA-DR の発現の低い例が多かった。

【結語】1)HLA-DRの表出程度はTIL, 胃癌の進行程 度，予後と密接な関連を持っていることが明らかとな った。2)肝転移例は非肝転移例に比へ HLA-DRの発 現率か低く，TILも少なかった。 3)手術時䀒転移例， 肝転移再発例のうち分化型癌てはHLA-DRの発現本が 低い症例が多かった。4)以上より HLA-DRは胃癌に おける腫瘦の進行程度や予後を反映する一因子と成り うると考えられた。
示-2 新しい增殖因子 H B - E G F の胃癌にお ける免度組織学的検討

大阪大学第 2 外科 ${ }^{11}$ 、生化学 ${ }^{21}$

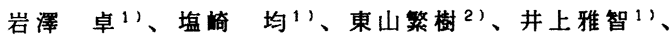

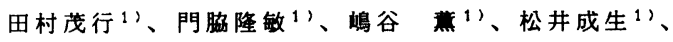
五福淳二 ${ }^{11}$ 、高山卓也 ${ }^{1}$ 、丸山菁太郎 ${ }^{11}$ 、中西純一 ${ }^{1}$ 、 谷口直之 ${ }^{21}$ 、森 武貞 ${ }^{1}$

【目的】Heparin-Binding Epidermal growth factorlike Growth Factor (以下HB-EGF) は、マクロファー ジの培養上清より同定された EGF familyに属する新し い增殖因子で、EGFより高いaffinityで EGF receptor に結合しそのautophosphorylationを惹起する。 in vitroでは線維芽細胞や平滑筋細胞の增殖を促進す ることが認められているが、invivoでの機能は未だ 十分に解明されていない。我々はこれまでに、抗 HB$\mathrm{EGF}$ 抗体を用いたヒ卜正常組織の免疫組織染色にて、 $\mathrm{HB}-\mathrm{EGF}$ は上皮に広く分布していることを報告してきた。 今回は、さらに胃密組織の免疫組織染色をおこない、 $\mathrm{HB}-\mathrm{EGF}$ 腫瘍内での局在を明らかにし、病理学的因子 との関連を検討した。

【方法】当科で最近約 1 年間に切除された胃密 36 例を 対象とし、それぞれの新鲜凍結切片をPFA固定後抗HBEGF polyclonal抗体を用いて $A B C$ 法にて染色した。染 色性の判定は、同じ手技で同時に染色した肺組織内の マクロファージを陽性コントロールとし、90\%以上の 癌細胞が晹性の場合を強発現とした。

【成績】正常周粘膜での染色性は、foveolar epitheliumからglandまでその細胞質に弱い発現を示し、 体部腺壁細胞および腸上皮化生部は強い発現を示した。 胃密組織では36例中 16 例 $(44.4 \%)$ が強発現を示した。 病理学的因子のうち組織型との関連では（強発現例／ 症例数，\%) はそれぞれ、tub1(3/9，33.3\%)、tub2 $(2 / 9,22.2 \%)$ 、por $1(0 / 2,0 \%) 、 \operatorname{por} 2(8 / 10,80.0 \%)$ 、 $\operatorname{sig}(3 / 4,75.0 \%) 、 \operatorname{muc}(0 / 2,0 \%)$ と、 por 2 に強発現例 が有意に多かった。また、間質量との関連では、背景 因子を揃えるため $\mathrm{pm}$ 以上の症例を対象とした場合、 scirrhous type(7/8, 82.5\%)、non-scirrhous type $(1 / 10,10.0 \%)$ と scirrhous typeに強発現例が有意に 多かった。他の病理学的因子とは有意の関連は認めら れなかった。

【結論】深達度、進行度との有意の関連が認められな かったことから、HB-EGFが単純に虎細胞の增殖を刺激 する因子ではないと考えられるが、por2やscirrhous typeに強発現例が多いことから、癌細胞が産生する HB-EGFが paracrine的に周囲のfibroblastの增殖を刺 激しコラーゲンなどの細胞外マトリックスの産生を促 し、スキルス癌の形成に関わっている可能性が示唆さ れた。 
示- 3 胃癌組織における type $\mathrm{N}$ collagenase, TIMP-2遗伝子の発現亡脈管侵襲との関連に関する検討

東京女子医科大学附属第二病院 外科 三浦一浩, 小川健治, 勝部隆男, 我妻美久, 若杉慎司, 平井雅倫, 渡辺俊明, 島川 武, 石川信也, 成高義彦, 矢川裕一, 梶原哲郎

【目的】癌細胞が転移する過程では，基底膜の破壊 がみられる。Matrix Metalloproteinase (以下MMP) はこの基底膜の主要構成成分である type $\mathrm{N}$ collagen を分解する醉素で， $72 \mathrm{kd}$-type $\mathrm{N}$ collagenase はそ の 1 つであり。転移能の強い腫瘍ほどその活性が高い と言われる。また, tissue inhibitor of metall oproteinase (以下TIMP-2) はこの酵素活性を特異 的に阻害する inhibitorで, これら両者は転移形成に 関与することが知られている。他方, 病理組織学的に みた脈管侵襲も, 血行性, リンパ行性転移に強く関わ る因子である。そてで今回, 胃癌組織における MMP およびT IMP - 2遺伝子の発現と脈管侵襲との関連につ いて検討した。

【対象と方法】1992年6月から 1993年12月までに当 科で切除された胃癌36例を対象とし, その癌先進部, 非敨部粘膜におけるMMPおよびT IMP-2遺伝子の発 現状況を検索した。方法は，GIT (Guanidine Isothi ocyanate) buffer で涷結保存した各組織加らIT-CsCL 法にて total RNAを抽出してRT ( reverse transcriptase) した後，cDNAを合成した。そして，RCR (polymerase chain reaction)法を用いて増幅し, 発現状況をみた。なお，脈管侵襲に関しては, 癌部の HE染色標本にて検討した。

【成績】 MMP, TIMP-2のmRNAの発現率は, 㿋 先進部では各 $94.4 \% ， 91.7 \%$, 非癌部粘膜では各 $80.6 \%$, 100\%であった。てれを脈管侵襲（v，1y)の有無別にみ ると, $\mathrm{v}(+) 13$ 例の癌先進部では各 $100 \%, 76.9 \%$, 非 癌部粘膜では各 92.3\%, 100\%, v(-)23例の癌先進部で は各 $91.3 \%, 100 \%$, 非稫部粘膜では各 $73.9 \%, 100 \%$ であった。さらに，1y(+)26例の扂先進部では各 $100 \%$, $92.3 \%$, 非癌部粘膜では各 $88.5 \%, 100 \%, 1 \mathrm{y}(-) 10$ 例 の癌先進部では各 $80 \%, 90 \%$, 非癌部粘膜では各60\%, 90\%であった。すなわち, 癌先進部では，脈管侵䧶陽 性例ではMMPがTIMP-2より多く発現するが,陰性 例ではその逆の傾向がみられた。また, 非癌部組織で はTIMP-2は100\%発現がみられたのに対し, MMP の発現は低く，とくに脈管侵裝陰性例では低率であっ た。

【結論】以上の成績より, 胃癌の脈管侵襲には MMP とT IMP-2が関連するととが示唆された。従っ て, 胃癌の転移は, これら㚐子が複雑に関与し形成さ れると考えられた。
示-4 P C R 法を用いた霊患者に於ける

G S T M 1 遭伝子久損の検討

筑波大学臨床医学系外科 ', 社会医学系 ${ }^{2}$, 大洗海岸病院外科 ${ }^{3}$, き医師会病院外科 ${ }^{4}$, 松田充宏', 石川詔雄 ', 原田勝二 ${ }^{2}$, 野末睦', 深尾立', 俣野重雄 ${ }^{3}$, 蒔苗徽 ${ }^{3}$, 足立信也 4 , 河島孝彦 4 , 石川智義“

[ 楮言 ] Glutathion S-transferase ( G S T) は 体外から取り込まれる、あるいは体内で生産される生 体異物と逼元型グルタチオンとの抱合反応を触媒する 解毒系酩素として知られ、発癌との関係でも注目され ている。我々はGSTクラスのうち、Muクラスに属 するM 1 locusの対立进伝子 3程類 ( 1,2 , gene deletion)の中で gene deletion が発癌のリスクフ アクターとなることを報告した ( Hum Genet 90:62 -64 1992 )。

今回我々は、Polymerase chain reaction ( P C R) を用いて、五癌患者の末梢血中のG S T M 1 遭伝子を Intron 6 とExon 7 の間で増幅し、霄癌のリスクフ ァクターとしてのG S T M 1 遭伝子の欠損頻度を検討 したので報告する。

[対象] 筑波大学付属病院およびその関連施設に、入 院中あるいは通院中の骨癌患者35名について検討し、

茨城県在住の健常者84名を対照とした。

[方法]末梢血 $500 \mu$ lをEDTA採血し検体とした。 D N A はプロテアーゼ处理、よう化ナトリゥム処理後、 インプロピルアルコール沈洞にて抽出した。P C R 法 は他のGSTMと相同性の少ないIntron6 をsense 銧プライマーとし、antisense 鎖プライマーとしては Exon 7 中のGS TM 1 A と G S T M 1 Bを区別する 点突然変異の塩基、すなわち $G$ さ Cだけ異なるものを 利用した。P C R は dNTPの量を通常の20倍ほど希积 したものにし、denature を9 ${ }^{\circ} \mathrm{C} て ゙ 1$ 分、annealing を $65^{\circ} \mathrm{C} て ゙ 2$ 分、extention を $72^{\circ} \mathrm{C} て ゙ 0.5$ 分に設定した。 以上を25サイクル行った。増幅したDNAは、アガロ 一ス電気泳動法を行いバンドを作成した後、エチジゥ ムブロマイドで染色し、紫外線照射下にバンドの有慜 を検討した。

[跿果] G S T M 1 遺伝子の欠损頻度は、健常者か 47.6\%であるのに対し、周癌患者では65.7 \%であり、 両群間に有為の差を認めた $\left(x^{2}\right.$ 検定。 $\left.P<0.025\right)$ 。 [考察] G S T M 1 遭伝子欠損は、肺庶に対するハイ リスクグループの発見に有効であることが期待されて いるか、、回の我々の検討ではの痖に対するハイリス クグループの有効な指標となることが示唆された。発 表時にはさらに症例を増やし、組權型との関連につい ても言及したい。 


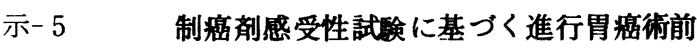
化学療法の適応選択に関する検討

岩手医科大学第 1 外科

寺島雅典, 池田健一郎, 川村英伸, 滝山郁雄, 高金明典, 前沢千早, 阿部毫, 大森浩明, 九傅史, 斎藤和好

【目的】進行胃癌に対する治療成績の向上を目的と して術前化学療法が実施され、その有効性について検 討されている。しかし、治療が奏効せす術前に腫瘍の 進展が認められる症例も少なくない。そこで、術前化 学療法の適応決定の一手段として内視鏡下生検標本を 用いた制癌削感受性試耠の有用性について検討した。

【対象と方法】1）制癌绪感受性試験：当科で治療を 受け、内視鏡下に $5 \sim 7$ 個の検体の採取できた胃癌 20 例を対象とした。制癌削感受性試験は無血清培養を用 いたATP法により、単細胞浮遊液を作製後、96穴 microplateに細胞を分注し、各種制癌绪と共に無血清 培地中で 72時間培養後、細胞内のATP量を定量して効 果を判定した。制癌郕の浱度は、臨床常用量の際の最 高血中浱度とし、数種の多都併用の効果についても検 討した。各楽郕処置群に打いて対照群に比べ、単郕で は50\%以上、多剤併用では70\%以上の增殖抑制が認め られた場合に感受性陽性とした。

2) 術前化学療法：8例の進行胃虎患者 $\left(\mathrm{N}_{4} 6\right.$ 例、 $\mathrm{H}_{3}$ 2例)に対して術前化学療法を実施した。制癌郕の投与 方法は、ADM $40 \mathrm{mg} / \mathrm{m}^{2}$ を第 1 日目に静注、CDDP $20 \mathrm{mg} / \mathrm{m}^{2}$ を第 1 日目か 5 5 日間点滴静注、5-FU $700 \mathrm{mg} / \mathrm{m}^{2}$ を同様 に 5 日間持続点滴静注とした。2 course 終了後効果判 定し、副作用の回復を待って手術を施行した。

【結果】感受性試験を実施した20例中17例 (85\%) で 制愿椷の感受性が判定可能であった。各制癌郕の感受 性陽性率は、CDDP 40\%、MMC 50\%、5-FU 33\%、ADM 50\%、VP-16 29\%であった。併用による感受性陽性率 は、 CDDP/5-FU 38\%、CDDP/VP-16 25\%, CDDP/5 -FU/ADM 73\%であった。術前化学療法が施行され た8例中 2例で出血のため緊急手術が施行されたが、 効果判定の可能であった7例中 5例で PRが、1例で MRが得られた。待機手術が施行された 6例中、PRの 1 例で根治度 Bの手術が可能であった。感受性試験 と 臨床効果との相関が 6 例で検討可能で、感受性試験の true positive rate $5 / 5(100 \%)$, true negative

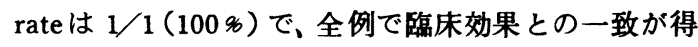
られた。

【結語】内視鏡下生検標本を用いた感受性試験は、 殆どの症例で感受性結果が判定可能であり、しかもそ の結果は臨床効果と一致しており、進行胃袺に対する 術前化学療法の適応選択に極めて有用な方法であると 思われた。
示- 6 胃病に対する Neoajuvant Chemotherapy の組 織学的および䤃素学的変化からみた有用性について

\section{近畿大学医学部外科学 II}

加藤道男、保田知生、黒田大介、泉谷 良、野口 淳、 堀 裕一、金田邦彦、奥本 鄙、野村秀明、西松信一、 河村正生、大柳治正

目的: 近年代謝拮抗刻の作用增強に種々の薬郕を併用 して良好な効果が報告されているが、この併用療法に よって奏功が期待される症例を把握することは容易で はない。そこで今回我々は術前切除可能と考えられる 症例に術前化学療法を施行し、切除標本における組織 学的変化と核酸合成に関与する䣼素の变化を検索し、 投与すべき菓剤が選択可能か否かを検討した。

対象と方法: 平成 4 年 9 月から平成 5 年12月までに当科 で手術を施行した胃癌症例16例を対象とした。術前化 学療法は切除可能と判断された症例に対して封筒法で Tegaful群 (T群) とTegaful+Cisplatin群（TC群）の2群 に分類した。投与法はT群にはTegaful $800 \mathrm{mg} / \mathrm{d}$ を2日間 投与し、TC群はTegaful $800 \mathrm{mg} /$ day とCisplatin20 $\mathrm{mg} / \mathrm{day}$ を術前2日間投与した。切除された胃癌病変の組織学 的検索はHE染色標本を用いて、胃癌取扱い規䄪の組 織学的効果判定基準に基づいて分類した。また測定可 能であった病巣に付いては、核酸合成に関与する de novo系の thymidilate synthetaseの阻害率（TSIR）と salvage系の thymidine kinase（TK）について検討した。 結果 : 対象症例の平均年齢はT群の56藏、TC群54歳で、 男女比はT群とTC群共に6:2と差はなかった。病理組織 学的評価可能病変はT群とTC群は共に8病変であり、 組織学的分化度ではT群は分化型1病変、未分化型7病 変で、TC群には分化型3病変、未分化型7病変であっ た。術前化学療法によって腫港細胞の変性や壞死を生 じた組織学的効果はT群にはみられなかったが、TC群 では8病変中の5 病変に $1 \mathrm{a}$ の効果と 1 病変には1 $1 \mathrm{~b}$ 効果 が認められた。またTSIRが $40 \%$ 以上と代謝拮抗剤によ る酵素への影響がみられたのはT群で6例中の1例、TC 群で4例中2例であった。TC群でTSIRが40\%未満でも TKが著しく高値の症例が認められた。

考察 : 今回我々は術前短期化学療法の有用性を検討し た。その結果、2殽併用のTC群に組織学的効果を認め た症例が多かったが、代謝拮抗剤併用でもde novo系の 合成䣼素阻害であるTSIRの上昇を伴わない症例で salvage系のTK高値が症例を認め、腫崵により核酸合 成系䤃素に差が存在すると思われた。また、T群にも TSIR上昇例を認めたことは、短期投与によって効果が 得られる症例では投与された薬郕に感受性が高いと推 定され、組織学的変化や醭素学的変動の把挃は術後に 使用する抗癌剤の選択に有用であると思われた。 


\section{示-7進行罱虫に対する5'-DFURと \\ OK-432によるPyNPase活性に及ぼす影骨}

群馬大学第二外科, 前标赤十字病院 ${ }^{1}$,

館林原生病院 ${ }^{2}$, 国立洪川病院 ${ }^{3}$, 公立票岡総合病院 ${ }^{4}$

佐蕉辟宏, 大和田 進, 小川暂史 ${ }^{1}$, 池谷俊郎 ${ }^{1}$,

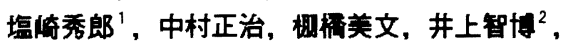

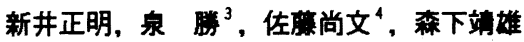

[目的] 進行罱湡に対する5’-DFURとOK-432による

PyNPase活性に及ぼす影䎡を検討した.

[対争と方法] 手術可能な進行胃满の術前急者をA群； 無治亦, B群；Doxifluridine（5'-DFUR）投与，C群； OK-432投与、D群；5'-DFUR+OK-432投与の 4 群に 分け，封简法による無作為試埃を行った. 5’-DFURは 術前に 5〜 7 日同 $800 \mathrm{mg} /$ body 経口投与とし, 标本 拉出 4 時同前に䍃投与を行った. OK-432は0.2KE.

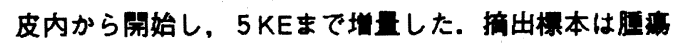

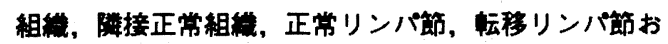
よび肝㬴組織とした.

[結果] 怔茜組絿のPyNPase活性佶は103 (gFU/mg protein/hr 以下省略), 险接正常組䋘で 53, 正常リンパ

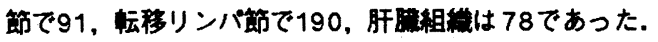

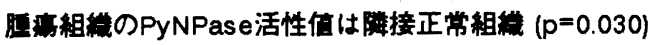
および肝滗組織 $(p=0.013)$ と比べ有意に高かった. また，枟移リンバ節は正常リンパ笛と比べ高い佰向

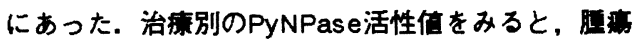
組維はA群 37 ，B群 96，C群 94，D群169であり，

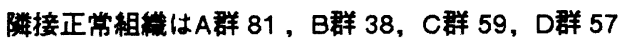

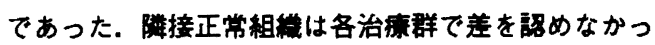

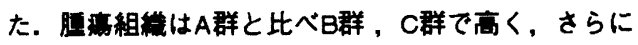
D群で高くなる傾向にあった. 怔率組織PyNPase活 性佶/陆接正常組維PyNPase活性佳はA群 0.45 , B群 3.69, C群 1.91，D群 2.8であった.

[考察] 5'-DFURは組蟣特異性のある化学廉法都 で、その理由の一つに䏠率組蟣のPyNPase活性位が 高いことがあげられており，本研究はそれを支持す る結果を得た. 兔疫賦活绪の一つであるOK-432の

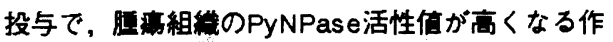
用權序は明らかでないが，単独投与より5’DFUR との併用で相加奻果を示しており，5’-DFUR投与時 の上年とは別の權序の関与が考元られる.

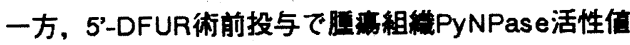
が低下するという報告もあり，さらに症例数を增や して検討中であり，その他にも5-FU湍度やTS阻害率 を含め多面的に検討し，報告する.
示-8 新規約よりみた $\mathrm{T}_{3}$ 胃癌根治切除例の治 療成績 : 特に、CDDP・IMC・Etoposide化学療法の成績

福井医科大学第一外科

広瀬和郎、飯田 敦、新本修一、片山寛次、 関 弘明、礒部芳彰、山口明夫、中川原儀三

『目的』新しい胃癌取扱い規約第12版に基づき、漿 膜浸潤陽性 $\left(\mathrm{T}_{3}\right)$ 胃癌根治切除例の治療成績を臨床病理 学的に検討するとともに、補助化学療法、特に、最近 5年間に行ってきたCDDP・rMC・Etoposideを用いた術中 腹腔内投与之術後全身化学療法の治療成䋶を報告する。 『対象』開院以来約10年間の胃癌手術例470例の内、 手術時に漿膜浸潤が明らかと判断され(旧規約の $\mathrm{S}_{2}$ ), 根治度Bの手術が行われた88例(男52例、女36例)である。 癌の主占居部位はA39例、r30例、C19例、肉眼型は1型4 例、2型28例、3型27例、4型15例、5型15例であった、47例 に胃全摘(膵脾合併切除32例、LUAE 5例)、41例に幽門側 胃切除が行われ、リンパ節郭清程度は $\mathrm{D}_{1} 2$ 例、 $\mathrm{D}_{2} 72$ 例、 $\mathrm{D}_{3}$ 14 例であった。最近 5 年間の肉眼型 3 型・4型の浸潤型癌 18例には、術中にCDDP100-150mg、YMC20mg、Etoposide $100 \mathrm{mg}$ が腹腔内投与 (ip)された。術後化学療法は、以 下の三法が行われた。A群(26例) : 経口阂(フッ化ピリ ミシン系)のみ、B群(50例) : 術後早期のIYC静注之経口 剂の併用、C群(12例) :CDDP・rrC・Etoposideの静注と経 口剂の併用。『治療成績』郭清度 $\mathrm{D}_{2}$ ट $\mathrm{D}_{3}$ の5年生存率 は44\%、52\%で、統計学的有意差を認めなかった。臨床 病理学的因子別に 5 年生存率を検討した。肉眼型: 1 型 50\%、2型54\%、3型42\%、4型0\%、5型42\%. 腫瘍長径 : $5 \mathrm{~cm}$ 末 満70\%, 5-10cm末満46\%, $10 \mathrm{~cm}$ 以上 $30 \%$. 組織型: pap50\%, tub $_{1} 44 \%$, tub $259 \%$, por $169 \%$, por $228 \%$, muc50\%. 深達度: ss60\%, se33\%. $n: n_{0} 42 \%, n_{1} 60 \%, n_{2} 23 \%, n_{3} 80 \%, n_{4} 0 \%$. stage: I $b(n=8) 73 \%$, II $(n=22) 66 \%$. III $a(n=16) 15 \%$, III $b(n$ $=28) 35 \%, I V 、(n=9) 75 \%, I V_{b}(n=6) 0 \%$. 即与, 組織型 por $_{2}$, 深達度 se, $\mathrm{n}_{2}$, stage III.以上の癌が予後不良であった。 再発形式の明らかな32例の内22例は腹膜再発であり、 その内20例が肉眼型浸潤型・por 2 で、大多数はstageが III以上であったが、I , IIでも、 por $_{2}$ でss・n $n_{0}-n_{1}, s e \cdot$ $\mathrm{n}_{0}$ の7例では腹膜再発を生じた。一方、遠隔蔵器(肝・ 肺・脳)再発8例の内，6例はtub $1, \mathrm{tub}_{2}$, por $_{1}$ (間質量が 髄様型・中間型)であった。腹膜再発予防のため抗癌阂 腹腔内投与が行われた 3 型・4型ip $(t)$ 群の 4 年生存率は 368 て3型・4型ip(-)群の388に比べ良好とは言えなかっ た。術後化学療法では、強化治療群であるC群の5年生 存率は41\%で、従来の標準治療群A, B群の51\%, 40\% ट差 異を認めなかった。「結論』(1)por 2 とその他の組織型 で再発形式に明らかな差異が見られ、この点を考慮し 補助療法が行うことが重要である。(2)CDDP・YrC・Etopo sideを用いた術中腹腔内投与、術後の強化全身化学療 法による生存率の向上は、現時点では明らかではない が、今後、さらに症例を重好て検討して行きたい。 


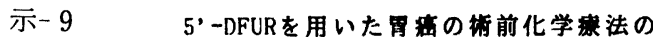
有用性についての検討

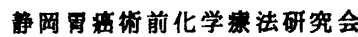
木村泰三*，中谷雄三、饭田其之、内村正幸、 室久敏三郎、長㜔孝昌、松本雄幸、北村宏、 柴田貢、森童夫、大墱光二郎、遗山和成、 原宏介、市川粑制、金丸化、㳊辺分利、 大久保忠俊、大盛芳路、森一茂、金子栄藏、 原田幸雄" (“浜松医科大学第一外科)

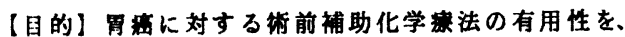

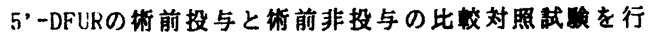
って、検討する。

【対象と方法】1990年11月から1993年10月までに静

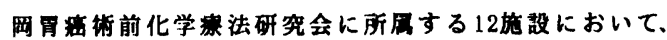
治䈍切除が可能と診断された胃窝症例を対象とした。 経口投与不能例、研究開始時に早期婹と到断された症

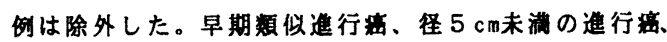

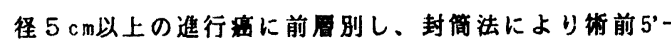
DFUR投与群 94 例と非投与群 84 例に分けた。泍前投与群 は、5'-DFUR $610 \mathrm{mg} / \mathrm{m}^{2} /$ 日を浙前に 10 日以上投与した。 術後は、両群ともMMCを術当日に $12 \mathrm{mg} / \mathrm{m}^{2} 、 1$ 日目に 6 $\mathrm{mg} / \mathrm{m}^{2}$ 静注し、2 用目より5'-DFUR $600 \mathrm{mg} / \mathrm{m}^{2} /$ 日を経口

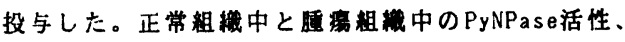
術後の生存事、湕存事につき娭尌を加えた。

【結果】PyNPase活性は投与群、非投与群ともに睡

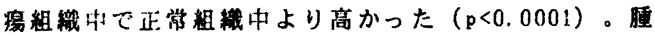
瘍組織 4 のPyNPase活性は、投与群 $123.9 \pm 87.7 \mu \mathrm{gFV}$ mg protein/hr $(n=53)$. 非投与群 $158.7 \pm 99.1(n=28)$ で、投与群で低俌を示した（p=0.0376）。正常組織中 のPyNPase活性は、投与群 $42.5 \pm 25.3(n=53)$ 、非投与 群 45. $5 \pm 35.8(n=31)$ で、差を認めなかった。得後の生 存率は、投与群で 1 年 $31.4 \%$ 、2年 $83.5 \%$ 、非投与群 で 1 年 $30.0 \% 、 2$ 年 $80.3 \%$ 、投与群で高かったか、 有意差はなかった。また、煡存率は投与群で 1 年 91.4 $\% 、 2$ 年 $76.6 \%$ 、非投与群で 1 年 $86.5 \% 、 2$ 年 $76.9 \%$ であった。

【考察】生存事、煡存率でみると、現時点では街前 化学凌法の有用性は証明されなかった。一方、PyNPase

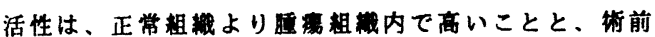

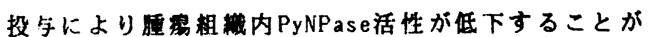
示された。PyNPaseが5’-DFURを5FUに㕠換する醭素で

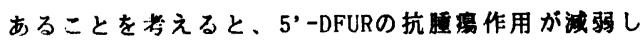
たとも考えられるが、PyNPaseを産生する腫震湅胞が 転移や悪液質を引き起こす湅胞であるとの仮定にたて

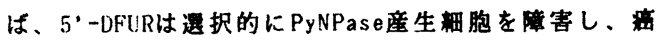

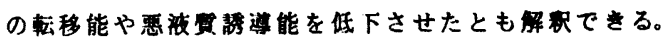
胃在我々は、IL-1の揤定や、ポリクローナル抗体を用 いて掣籍粗織中のPyNPaseの染色を行い、PyNPase活性 の低下の意味について娭討中である。
示-10 高度進行周䑩に対する neoadjuvant che motherapy：F P L (5FU、CDDP、leucovorin) 廉法の 有用性およびEA P (Etoposide、Adriamycin、CDDP) 撚法との比较

大阪大学第 2 外科、・関西労災病院外科 辻仲利政、㙁崎均、村田厚夫、西崔準一、井上雅智、

梅下浩司、山崎恵司・、今本治彦・、森武貞

【目的】初回切除不能の高度進行用清に対し、術前 化学瘦法を行った後、同切除を追加することにより生 存期間の延長が得られる可能性がある。Biochenical modulation作用を応用した 5 F U、C D D P とleucov orinの 3 者併用㩧法（F P L）は、周盤に対する高い 有効性が期待される。今回 F P L 癔法を行った結果を E A P 療法と比较しつつ、報告する。【方法】息隔転 移や明かな腹膜漫润（転移）のため切除不能と判定さ れた進行周悹忠者に対し、F P L 㾣法を19例に、E A P 瘦法を14例に行った。その後、治療効果、副作用、切除率 および予後について検討を加えた。F P L 療法のレジ メは、 $5 \mathrm{~F} \mathrm{U}\left(750 \mathrm{mg} / \mathrm{m}^{2} ; \mathrm{day} 1-5\right) 、$ C D D P $\left(70 \mathrm{mg} / \mathrm{m}^{2}\right.$; day 1), leucovorin (20mg/m ; day1-5)であり、E A P 存 法はA D M $\left(20 \mathrm{mg} / \mathrm{m}^{2} ; \mathrm{day} 1,7\right) 、$ C D D P $\left(40 \mathrm{mg} / \mathrm{m}^{2} ; \mathrm{day}\right.$ 2.8)、etoposide $\left(100 \mathrm{mg} / \mathrm{m}^{2} ;\right.$ day $\left.4,5,6\right)$ であり、それぞ れ 2 クール行うことを原則とし、治痖効果が得られる と判断された症测に切除術を行った。【結果】F P $\mathrm{L}$ 症例での評価可能病変は、周（全例）、リンバ節（10 例）、肝（7例）、腹水（3 例）、肺（1 例）であった。 E A P 症例では、胃（全例）、リンパ節（10例）、䀒

（2例）、腹水（4例）、骨（2例）であった。総合 評価における奏効率はF P L : 53\%(10/19)、E A P 14 $\%(2 / 14)$ であった。病变別における奏効率はF P L で は A B 病变 $60 \%(6 / 10) 、 \mathrm{C}$ 病変 $44 \%(4 / 9)$ であり、E A $\mathrm{P}$ では $\mathrm{A} \mathrm{B}$ 病变 $25 \%(2 / 8) 、 \mathrm{C}$ 病変 $0 \%(0 / 6)$ でった。 また腹水蓄留例は両療法において奏効例はなかった。 Grade 4 の白血球減少をF P L $5 \%$ 、E A P $18 \%$ に認 めた。周切除率はＦＰ L 42\%(8/19)、E A P 57\%(8/15) であり、絶対非治惠切除の割合はそれぞれ38\%(3/8)、 $88 \%(7 / 8)$ であった。局所（腹膜転移を含む）とリンパ 節転移が主体の比較的限局性の病变とそうでないすの の予後はF P L 12.5M、5.8M、E A P 7.1M、6.2Mであり、 F P L では有意に限局病变の予後が良好であった。全 症例の予後はF P L 7.3M、E A P 7.3Mと両璂法で差を 認めなかった。切除例の予後はそれぞれ12.5M、10.9M であり、非切除例は5.8M、5.4Mであった。【結論】F P LはE A P 癔法に比較し、全体として予後の差はなか つたが、副作用が軽く奏効率が高かったため、neoadjuv ant のレジメとしてょり優れていると考えられた。ま たF P L 療法において追加周切除術は有意の予後延命 効果を有していた。腹水陰性の限局性病変がF P L に よる術前療法の最すよい適応と考えられた。 
示-11 組織学的抗腫瘍効果とTS阻害率からみ た胃癌におけるNeoadjuvant Chemotherapyの有用性

\section{福岡大学第 1 外科}

田中伸之介, 梅野寿実, 光石和夫, 木村博, 冨田昌良, 㴊野泰秀, 大塚吉郎, 森 寿治, 中村 浩, 池田靖洋

【目的】術前化学療法併用による進行胃癌の予後向上 を目的に、Biochemical Modulationの概念に基ついた CDDP/UFTによるNeoadjuvant Chemotherapyを行い、組織 学的抗腫瘍効果之腫瘍組織内のThymidylate synthase阻 害率(TSIR:\%)からみた同療法の有用性を検討した。

【対象と方法】1991年7月から1993年9月までに当科で 外科的切除を行った胃癌症例中、70歳未満で全身的合 併症がなく、術前診断で進行癌と診断された24例に CDDPおよびUFTの術前投与を行った。CDDPは $40 \mathrm{mg} / \mathrm{m}^{2}$ を点滴静注投与し、UFTは術前約 1.3 週間前 より $400 \mathrm{mg} /$ dayを経口投与した。腫瘍摘出後、速やか にその一部を採取のうえ凍結保存し、腫瘍組織内の TSを測定しTSIRを求めた。また腫瘍の組織学的抗腫 瘍効果を胃癌取扱い規約(改訂第12版)の組織学的効果 判定基準に基つき行った。

【結果】対象は男性:18例、女性:6例、平均年齢:59.2歳 であった。CDDPの平均投与量は $61.1 \mathrm{mg} /$ body、平均投 与日は術前6.6日、UFTの平均投与日数は12.9日、平均 総投与量は $5.0 \mathrm{~g} / \mathrm{body}$ であった。術前投与による合併症 はなく全例に予定手術が施行された。腫煌組䅧型は乳 頭状腺癌: 3例、高分化型腺癌: 1例、中分化型腺癌: 4例、 低分化型腺癌: 14 例、粘液癌: 2 例、深達度は $\mathrm{t}_{1}: 2$ 例、 $\mathrm{t}_{2}$ : 3例、t $3: 18$ 例、 t $4: 1$ 例、stageは I a : 2例、I b : 1例、II : 5 例、III a : 3例、IIIb :4例、IV a :2例、IVb : 7例であっ た。組織学的抗腫瘍効果はGrade 0: 8例、Grade 1a:10例、 Grade 1b: 5例、Grade 2: 1例であり、TSIR は 10\%未満 : 2 例、 $10 \%$ 以上 $20 \%$ 未満: 4 例、 $20 \%$ 以上 $30 \%$ 未満: 6 例、 $30 \%$ 以上 $40 \%$ 未満: 5 例、 $40 \%$ 以上 $50 \%$ 未満: 3 例、 $50 \%$ 以 上: 2例、測定不能: 2例で平均: $29.0 \%$ あった。Grade 別 TSIR平均値は Grade 0: $22.44 \%$ 、Grade 1a: $28.30 \%$ 、 Grade 1b: $35.00 \%$ 、Grade 2: $45.49 \%$ 、逆にTSIRが $20 \%$ 末 满ではGrade 0: 3例、Grade 1a: 3例、20.0\%以上 $40.0 \%$ 未 満ではGrade 0: 2例、Grade 1a: 5例、Grade 1b: 4例、40.0 \%以上ではGrade 0: 1例、Grade 1a: 2例、Grade 1b: 1例、 Grade 2: 1例であった。即ち、抗腫瘍効果が大きい程 TSIRが高く、TSRIが高い程抗腫瘍効果が大きい傾向 がみられた。

【結語】CDDP/UFT術前投与で24例中16例 (66.7\%)に変 性・壊死などの組織学的効果がみられ、組織学的抗腫 瘍効果之組織内TSIRには相関傾向がみられた。TSIR を向上させ得る薬剂の投与期間や投与量の再検討によ り、down stagingや微小転移巣に対する効果が期待で きNeoadjuvant Chemotherapyとしての有用性が示唆され た。
示-12周营の neoadjuvant chemotherapyにおける 薬都遣択の評洒法 和䎶山県立医科大学 消化器外科

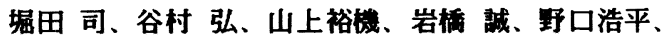

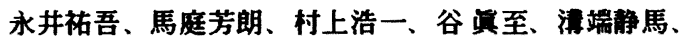
寺㴖 宏、石本高和男、谷口勝俊

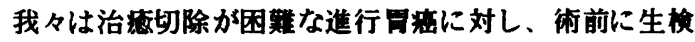

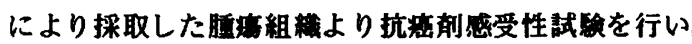
その結果に従ったneoadjuvant chemotherapyを行ってい

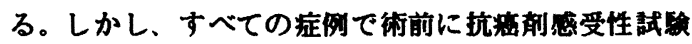
ができるわけではなく、そのような症例では経䩀的な 菜詴㟟択が必要となる。今回、neoadjuvant chemo-

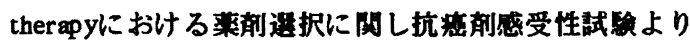
みたCDDPと5FU併用の意義およびその臨床的有用性を 検叶した。

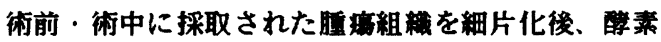

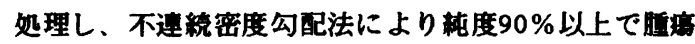

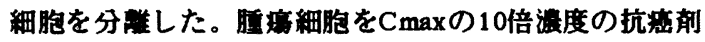
とともに3日培養しMTTと反応させた後、フォルマザン を溶解しマイクロフレートリーダーにより吸光度を測 定しSD活性を算出した。

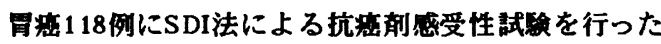

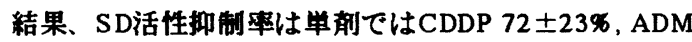

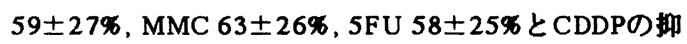

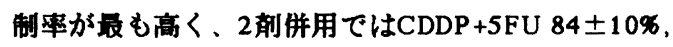
$\mathrm{MTX}+5 \mathrm{FU}$ 66士21\%であり、CDDP+5FUがADM, MMC, 5FUよりも感受性が有意に高いことがわかった。また 組維学的には、未分化型ではCDDP+5FUが 88\% と非常 に高い抑制率を示した。したがって neoadjuvant chemotherapyとしてCDDP+5FUの組合わせが効果が期 待できることがわかった。

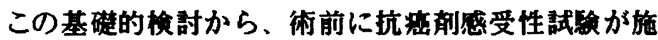
行できず治黄切除術が困蜼な進行胃虫6例(すべて低分

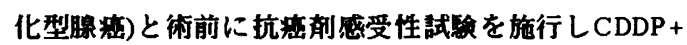

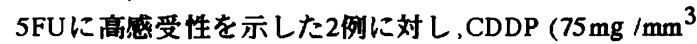
div)と 5FU( $750 \mathrm{mg} / \mathrm{mm}^{3} \mathrm{civ}$ )併用のneoadjuvant chemotherapyを2クール以上行った結果、原発莜の縮小を4例 に、枟移师 飾の消失あるいは縮小を5例に認め、8例 中5例に治曼切除が可能となった。副作用はGrade1の悪 心を4例に認めたのみであった。また8例中、術中摘出

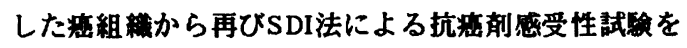
施行できた症例は4例あり、そのうち3例は CDDP +5FUが高感受性を示しその後のadjuvant chemotherapy も同じ方法で行った。しかし，1例はすでにCDDPと 5FUに耐性を生じており、次の投与の有効性が资問視 された。

以上より、進行冒苾に対する neoadjuvant chemotherapyとして使用する莱削はとくに CDDPと 5FUの併 用が推められるが, 頻回の再評洒を必要とする。 
示-13低分化型進行胃癌に対する CHPP併用 MTX-5FU交代療法

長崎大学第一外科、同 医療短期大学部

宮下光世、草野裕幸、松尾俊和、松本佳博、

内川徹也、三浦敏夫富田正雄

【目的】低分化型進行胃癌はしばしば腹膜転移を来し再 発する。腹膜転移再発の予防や治療として持続温熟腹膜 灌流法(CHPP)が試みられているが、その効果は充分と はいい難い。その理由として腹膜転移巣の形態や同時に 存在する全身のリンパ節転移や血行性転移が考えられ る。そこでこれを克服するためにCHPPに続き低分化型 胃癌に有効であるMTX-5FU交代療法を全身療法として 行うCHPP併用MTX-5FU交代療法を考案し、低分化型進 行胃癌に対して試みた。またCHPPの効果予測の目的で 施行前後の腹水及び腹膜転移組織の Flowcytometry (FCM)によるDNA histogramの変化につき検討した。 【対象及び方法】1992年2月から 1994年1月に教室で経験 した低分化型進行胃癌で手術時槳膜因子陽性の10例 （19-66才、男6例女4例、stage III 2例 stage IV 8例、 $P_{0} 3$ 例 $P_{1} 1$ 例 $P_{3}$ 6例）を対象とした。方法は原則として開 腹後原発巣を切除可能な症例では切除後、 CDDP300mg、Etoposide300mgを溶解した生食水 $3000 \mathrm{ml}$ にて $42^{\circ}$ C50分間加温灌流した。術後約 2 週後より MTX$5 F U$ 交代療法（MTX $100 \mathrm{mg} / \mathrm{m}^{2}, 5 \mathrm{FU} 600 \mathrm{mg} / \mathrm{m}^{2}$ ）を4-6 クール以上施行した。

【成績】(1)術前中等量以上の腹水をみとめた $\mathrm{P}_{3}$ の5症例 全例において腹水の消失をみとめ、その後も1例を除き 最長11カ月腹水のコントロールが可能であった。(2)開 腹時腹水細胞診陽性であった6例中4例にCHPP後腹水 細胞診の陰性化をみた。(3)FCMにてaneuploidy peakの 消失やS期の減少としてCHPPの効果が予湘できた。 CHPP後も細胞診陽性の1例はCHPP前のaneuploidy peak が消失しその後1週間で腹水は消失しCHPPの効果が予 測できた。(3)切除可能であった $\mathrm{P}_{3}$ の1例は、6力月後イ レウスにて再入院となるまで良好なQOLが得られた。

(4)P ${ }_{1}$ の1例では下利のため投与を中止したが、リンパ節 再発が消失した。現在腹壁再発を来したかMTX-5FU療 法を再施行し良好にコントロール中である。(5)根治手 術ができた3例は1994年2月現在いずれも disease free で最長17カ月生存中である。(5)副作用としてCHPPでは 急性腎不全、麻ひ性イレウス、縫合不全がみられたが、 いずれも保存的に回復した。MTX-5FU交代療法では grade 4の下莉を1例にみとめたが他に重篤なものは経 験しなかった。

【結論】(1)本法は腹膜転移陽性胃癌の腹水コントロー ルに有用である。延命効果に対しては充分とはいえない がQOLの改善に関しては有用である。(2)腹膜転移陰性 胃癌では現在のところ再発もなく良好な結果であるが 観察期間も短く予後に関しては更に経過をみる必要が ある。(3)FCMにより治療効果の予測が可能である。

\section{示-14多発胃瘦の庹床病理学的㛟討}

\author{
藤沢市民病院外科 \\ 森脇義弘、小林俊介、国崎主税、原田博文、 \\ 今井信介、城戸泰洋、笠岡千孝
}

【目的】多発胃艘は胃症症例の䄪 $10 \%$ 瑟められる という。今回、我々が過去に経験した多発胃症症例を

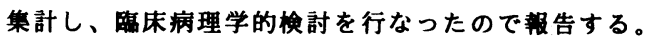

【対象と方法】藤沢市民病院外科で過去15年间に手 術を行なった胃症症例980例のうち切除胃に2個以上の 瘦病巣を認めた 38 例(以下多発群)を対象とし、切除胃 の瘦病巣が1個のみであった 942 例(以下対照群)と発生 部位、組織型、組織学的梁達度、リンパ節枟移、ステ ージ、遠隔成請を比校検討した。記载は、症例が過去 のものであるため改定前の旧規䄪に基づいた。

【結果】年紷は対照群が平均60歳、多発群は63黹で あった。肝枟移、腹膜播腫は、対照群の $12 \% 、 23 \%$ が閶 性であったのに対し、多発群では全例陰性であった。 発生部位は、対照群ではA中心が $45 \% 、 M$ 中心が $31 \% 、 C$ 中心が $14 \%$ 、全領域に及ぶものが $10 \%$ あ゙った。多発 群でも、全例M、Aのいずれかに1病変があり、C-Mが $13 \%$ 、

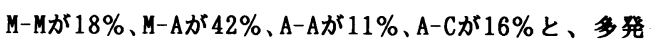
病病巣の全てがM、Aに含まれるのが $71 \%$ あったが、29 \%はC領域にも病巣を有していた。組桟型では、分化 型(tub1、tub2、pap)は対照群で $38 \%$ 、多発群で $45 \%$ と 差を認めなかった。組織学的深達度は、対照群ではm、 $\mathrm{sm} 333 \%$, pm、ssは $25 \%$ 、PS陽性は $42 \%$ であったのに 対し、多発群の最も梁達度の深い主要病変ではm、smが $66 \% 、 \mathrm{pm} 、 \mathrm{ss}$ は $13 \%$ 、PS陽性は $21 \%$ と、多発群で早期 貘が多かった。リンパ節枟移、リンパ营漫恶は、対照 群では $48 \%$ 、57\%に諗められたのに対し、多発群では 22 $\% 、 33 \%$ と低率であった。ステージは、対照群ではス

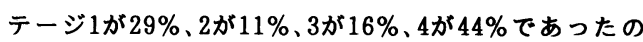

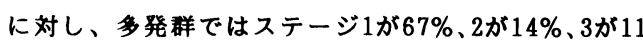
$\% 、 4 ふ ゙ 8 \%$ 之多発群でステージの低いものが多い傾 向にあった。遠隔成精は、対照群の5年生存事 (KaplanMeier法による)はステージ1で95\%、2で62\%、3で34\%、 4 で $3 \%$ 、多発群の 5 年生存事はステージ1で $95 \% 、 2 て ゙ 75$

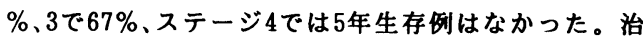
急切除例に限っても、対照群ではステージ1で95\%、2

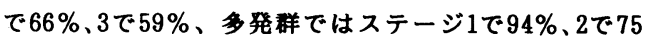
\%、ステージ3(4例)では死亡例はなかったが、多発群 のステージ别遠隔成䛾は対照群のそれと差がなかった。

【考察】多発胃盤は早期に発見されることが多く、 その予後は進行度の同じ単発の胃富と同等であった。 しかし、多発病巣のひとつがC領域に存在する場合も 䄪 $30 \%$ あり、胃癌の内視鏡検査では多発胃癌を常に念 頭において胃全体の詳細な覞察を行なうことが重要と 思われた。 
示-15

多発胃癌の臨床病理学的検討

川崎医科大学消化器外科

木元正利, 忠岡好之, 吉田和弘, 藤森恭孝, 岩本末治, 牟礼 勉, 笠井 裕, 今井博之, 伊木勝道, 小沼英史, 山本康久、角田 司 目的

多発胃癌は発生学的興味や残胃重複癌の診断といっ た問題だけでなく，臨床治療上，副病巣を残胃に遺残 させることなく全てを完全に切除するという点で重要 である。今回我々は教室例を検討し, 本症に対して臨 床病理学的な検討を行ったので報告する。

対象および方法

教室の開設以来1993年12月までの20年間に切除され た胃癌症例1667例から loertelの診断基準に相当する 多発胃癌症例を集積し, 臨床病理学的に検討した。 主病変は深達度が深いもの, 同じ場合は大きいものと し, 他は全て副病変として深達度, 肉眼形態, 癌病巣 数, 組織型, 病変の大きさ, 病変の位置関係および病 変間距離，口側及び肛門側断端までの距離と小弯軸に 対する関係，診断時期之確定診断法，予後との関係な どについて検討した。

結果

多発胃癌症例は男性68例，女性28例の計96例あり， 切除胃癌全例に対する頻度は5.8\%であった。男女比は 2.4:1であったが, 単発胃癌とほぼ同様で発生頻度に 差はなく，平均年齢も59.4才で単発胃癌とほぼ同じで あった。主病変の大きさは長径で1.2-12.8cmで平均5. $2 \mathrm{~cm}$, 副病変の大きさは $0.1-8.0 \mathrm{~cm}$ で平均 $1.8 \mathrm{~cm}$, 深達度 をみると早期癌どうしの組合せが圧倒的に多く, 進行 度どうしの組合せは10例であった。特に近年, 早期癌 の占めろ割合が增加している。副病変の深達度は粘膜 固有層に限局するものが圧倒的に多く, 約 $70 \%$ 的癌 であった。形態的には主病変は単発癌と同様であるが 最近では早期癌類似進行型が増加している。副病変は II c あるいはII a がほとんどであった。主・副病変間

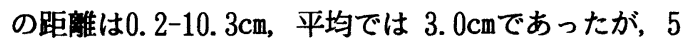
cm以上離れているものが $22 \%$, 副病変が口側に位 置しているものが 40\%を占めた。診断は初期には術中 の触診や切除標本の肉眼的検索で発見されるものが多 かったが, 最近ではほぼ術前に確認されるようになっ ている。病変数では 2 重複がもっとも多く約70\% を占 めるが, 切除胃全域に不連続の病巣が散在している例 も有り，1個の副病変のみの発見に安心せず, 全域の 観察が必要と思われる。副病変のためにowまでの距離 が短縮する場合が約 $30 \% に$ 見られ，ow陽性となり再手 術を施行した例も経験した。本症の存在を常に念頭に 置き, 術前の充分の検索と切除胃の詳細な観察を行い 見逃さないように注意することが重要と考えられた。
示-16多発早期冒瘦症例の臨床病理学的検討と外 科的治療上の問題点

金沢大学がん研究所外科

酻口雅之、伊藤透、藤岡央、黄承東、安本 和生、出口 康、藤本敏博、大井章史、高橋巷、 磨伊正義

[目的]同時性多発早期胃密の存在は、外科的治富上 胃切除断端の決定、言い換えれば残胃に爱を取り残さ ないための治境上の問題がある。そこで、当科で経倹 した同時性多発早期置臨床病理学的検索を行ない 外科的治療上の問題点、本症例における pitfallとそ の対策について検討した。

[対象・方法] 当科開設以来 15 年間に切除さ九、か つ全割された早期骨在 428 症例を対象とした。切除 胃はすべて $5 \mathrm{~mm}$ 幅で全割され、臨床病理学的に模討 した。

[結果] 428 症例の切除罥全割標本の組織学的検索

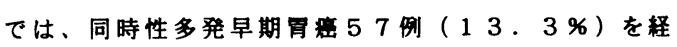
输している。57症例のうち男性 48 症例、女性 9 症 例で男女比は $5: 1$ と男性に多く、平均年龆は 62 .

8 歳で、特に 70 歲以上の占める割合が $30 \%$ 以上と 高い傾向を示した。同一症例で深達度の進んでいる病 変もしくは腫得の大きい病変を主病変とし、その他 を副病変とした。その主病変・副病変の位置関係をみ ると、副病変が主病変の口側に位囬するものが 25 症 例（42．1\%）を占めた。このことは外科的切除楾 決定上問題となる。肉眼型についてみると同時性多発 早期胃㾜 57 例 147 病変ではI $\mathrm{c}$ を主体とした陷凹 型が 79 病変（５４．1\%）を占め最も多く、その組 み合わせは、隆起型は隆起型、陷凹型は陥凹型の組み

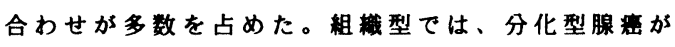
116 病変 $(78.8 \%)$ と多数を占めた。主病巣と 副病巣の組織型の組み合わせでは、分化型同志の組み 合わせが 40 症例（７０．1％）であった。発生部位 による分類では暮樎領域を含めた㗀門腺領域での発生 が多数を占めた。

[結語]高踰者、男性の早期胃社は主病紧の嗔門㑚に 副病紧が存在する頻度が高く、切除線の決定に際して は、腺境界領域を識別し、胃粘膜面の微細な变化を捉 えることにより病変の多発性とその拡がりを的確に把 握することが重要である。 
示-17

一単発早期胃癌との比較 -

爱媛県立中央病院外科

喜安佳人、酒井堅、河崎秀樹、吉富一、西浦三郎

長珮順二、西臀三郎、木村誉司、重松 授、田中富雄

【目的】早期胃癌に対してQOLの観点から縮小手術が武 みられてはいるが、一方残胃の別の癌病変の存在にも 注意し、取り残しのないようにする必要がある。そこで 同時性多発早期胃癌を監床病理学的に検討したので報 告する。

【対象と方法】1988年から1992年までの5年間に当科で 手術を受けた早期胃癌170例について単発胃癌160例、 160 病变 (単発群) と同時性多発胃癌 10 例、 24 病変 (多発 群)とを臨床病理学的に年龄、性、発生部位、肉眼型、組

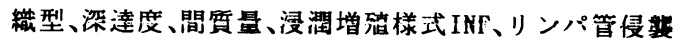

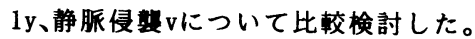

【結果】(年柃)単発群は 21 嵅から84歳、平均61歳で多発 群では53歳から84歳、平均64歳で、多発群に若年者はな かった。(性別)単発群は女58例、男102例で、多発群では 女3例、男7例であった。(発生部位)単発群では $\mathrm{A}: 75$ 例、Y $: 74$ 例、C:11例で、多発群では $\mathrm{A}: 11$ 例、 $\mathrm{N}: 12$ 例、C:1例で両 者に差はなく、領域に多いということもなかった。ま

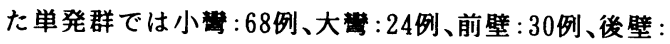
35 例、全周: 3 例であり、多発群では小洌、大 $: 2$ 例、 前壁: 8 例、後壁: 3 例で多発群で小彎に多い煩向があっ た。(肉眼型) 単発群では1型: 8 例、】a型: 10 例、【b型: 10例、 Ic型: 92 例、複合型 40 例であり、多発群ではl型: 1 例、【a 型 : 0、【c型 15 例、複合型4例で両者とも』c型が多かった。 (組織型) 単発群では乳頭腺癌 pap : 9 例、高分化型管状腺 癌 tub1:58例、中分化型管状腺癌 tub2:32例、低分化型腺 癌por: 29 例、印環細胞癌sig: 32例であり、多発群では pap: 1 例、tub1:15例、tub2:6例、por:2例、sig:0例で多発 群には分化型腺癌が多かった。(深達度)単発群では粘 膜層 $\mathrm{m}: 122$ 例、粘膜下層 (軽度) $\mathrm{sm} 1: 38$ 例であったが、多 発群ではm: 21 例、sm $1: 2$ 例、 $\mathrm{sm} 2: 1$ 例で梁達度は多発群に 浅いものが多かった。(間質量)単発群では檤様型: 36例、 中間型: 121 例、硬性型: 3 例で、多発群では膸様型: 2 例、 中間型: 22 例で、多発群には硬性型はなかった。(浸潤增 殖様式INF) 単発群では $a: 47$ 例、 $\beta: 91$ 例、 $r: 22$ 例で、多発 群では $a: 7$ 例、 $\beta: 17$ 例でท:0例で、多発群には浸洞性の增 殖を示すものはなかった。(リンパ管侵襲1y)単発群で は $1 \mathrm{y} 0: 151$ 例、 $1 \mathrm{y} 1: 8$ 例、 $1 \mathrm{y} 2: 1$ 例で、多発群では $1 \mathrm{y} 0: 23$ 例、

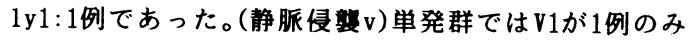
であり、多発群は全例 $\mathrm{V} 0$ であった。

【結論】同時性多発早期胃癌を臨床病理学的に検討した 結果田若年者には少なく、略化型腺癌が多く、樑達度

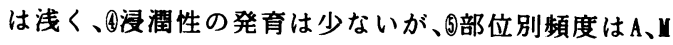
領域に差はなく、術前の存在浐断之共に切除線の決定 には注意を要することが示唆された。
示-18 胃癌再発例に対する再手術の検討 国立療養所敦賀病院外科 澤敏治、藤田 隆、 浦出雅昭、富田 寛、吉光外宏

〔目的〕胃癌再発症例に対し、やむなく再手術を決断 する場合、画像診断が発達した今日でも的確に再発形 式を診断し、術式を術前予測するてとは極めて困難で ある。そてで今回再手術した再発胃癌について検討し たので報告する。

〔対象〕1981年〜1993年までに当科で経験した原発胃 は477例であり、うち再手術を21例に23回施行した。 〔結果〕再手術の原因は大多数か消化管狭窑であった が 2 例は化療効果が得られ再切除した。再手術 21 例の 初回手術は治窑切除 14 例、非治痹切除 7 例である。再 発形式は腹膜 12 例、肝 2 例、リンパ節 1 例、局所 2 例、 複合 4 例であった。再手術術式は根治的切除 6 例、姑 息切除 8 例、吻合 7 例となった。予後は姑息切除、吻 合例 1 年以上生存は得られず各々平均 29 週 $(20 \sim 40)$ 、 14 週（ $2 \sim 42$ ) であった。根治的再切除例は 2 年以上 生存が 3 例みられ、うち 1 例は 6 年 4 ケ月生存中であ る。根治的再切除を以下に示す。

\begin{tabular}{|c|c|c|c|}
\hline 初回手術 & 再発形式 & 再 手 術 & 予 後 \\
\hline $\mathrm{H}_{0} \mathrm{P}_{0} \operatorname{sen}_{2}$ & 腹 膜 & 腸切、卵摘 & $6 \mathrm{Y} 4 \mathrm{M}$ 生 \\
\hline $\mathrm{H}_{0} \mathrm{P}_{0} \sin \sin _{0}$ & 膜 & 直腸切断 & 2 Y 9 M死 \\
\hline $\mathrm{H}_{0} \mathrm{P}_{0} \mathrm{ss} \beta \mathrm{n}_{1}$ & 所 & 膵頭切除 & 2 Y 2 M死 \\
\hline$H_{0} P_{1}$ sen $_{1}$ & 複 & 左上腹部 & $11 \mathrm{M}$ 死 \\
\hline $\mathrm{H}_{1} \mathrm{P}_{0} \mathrm{smn}_{0}$ & 肝 & 肝切 & 6 M死 \\
\hline $\mathrm{H}_{0} \mathrm{P}_{0} \mathrm{sm}$ & 局 & 左上腹部 & 4 M死 \\
\hline
\end{tabular}

〔まとめ]胃癌再発にて再手術した21 例中 6 例に根治 的再切除を施行し得た。又姑息切除は 8 例、吻合は 7 例となった。予後は根治的切除例では 2 年以上生存が 3 例得られうち 1 例は 6 年 4 ケ月の現在生存中である。 又姑息切除、吻合例では 1 年以上生存は得られなかっ たが、退院可能となりQＯLの改善が得られた。また 化学療法の発達により著明な効果か得られ再切除し得 た 2 例を経験し、今後化療後再切除症例の可能性が増 大するものと思われる。

以上再手術に際してQO L の改善及び延命効果も得ら れる症例もみられ適切な術式の選択が重要と思われる。 
示-19 胃癌血行性転移の特徴

福岡大学筑紫病院外科

西田哲朗，有馬純孝，二見喜太郎，山崎宏一， 岡本達生, 古藤 剛, 立石訓已, 立石修三, 稲田繁充，原 文昭，大河原建也，長谷川修三， 喜多村邦弘，原田洋子，福井チナミ，東大二郎

（目的）胃癌の血行性転移と肝転移の治療について 検討した。（対象と方法）1985年7月より1992年12月ま でに経験した胃癌496例中、入院時肝転移が認められら 症例 $(\mathrm{H}(+)$ 症例 $)$ と初回手術時、治癒切除または相対 非治癒切除がなされた後、肝再発を来した症例を合わ せた群をLM群、その他の血行性再発をDM群、開腹時 腹膜播種がみられた症例（P(+)症例）之初回手術時、 治癒切除または相対非治癒切除がなされた後、腹膜再 発がみられた症例を合わせた群をPM群とした。

(絬果) LM群は28例 (5.7\%) ( $\mathrm{H}_{1} ; 4$ 4例、 $\mathrm{H}_{2} ; 6$ 例、 $\mathrm{H} 3 ; 8$ 例、肝再発；12例、但し、重複が2例あり）、 DM群は4例 $(0.8 \%)$ （骨；2例、肺；1例、大腸、皮膚、 残胃に血行性転移1例）、PM群は61例 (12.3\%)（P1； 10例、 $\mathrm{P}_{2} ; 4$ 例、 $\mathrm{P}_{3} ; 22$ 例、腹膜再発 ; 25例) であっ た。尚、LM群とPM群には重複例が4例 ( $\mathrm{P}_{3} \mathrm{H}_{3} ; 2$ 2例、 $\mathrm{P}_{3} \mathrm{H}_{1}$ ；2例）みられた。臨床病理学的因子を比較する 亡、年齢はLM群は、70.0歳でPM群61.3歳（p<0.01）、 DM群61.0歳（p<0.05）より有意に高龄であった。男 性の割合はLM 群は75\%、PM群は65.6\%、DM群は75\% であった。肉眼型はLM群にBoormann2型が60.8\%、PM 群に4型が $61.4 \%$ と各々有意に $(\mathrm{p}<0.01)$ 高率であっ た。DM群に4型はみられなかった。腫瘍最大径はLM群 $5.4 \mathrm{~cm} 、$ DM群 $5.4 \mathrm{~cm} 、$ PM群 $9.3 \mathrm{~cm}$ でPM群が有意に $(\mathrm{p}<$ 0.01) 大きかった。深達度はmからssまではLM群69.6

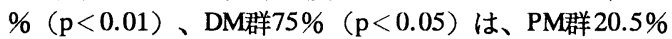
より各々有意に高率であった。組織型では分化型がLM 群は64.3\%でPM群 (32.2\%) より有意に（p<0.01） 高率であった。DM群75\%であった。そのほかLM群に INF $\alpha$ 、ly2までが有意に高率であった。n因子、v因子、 転移リンパ節個数に差はみられなかった。生存率およ び50\%生存期間はLM群 $17 \%$ 、13.3力月、PM群4\%、 11.0 力月、DM群 $37.5 \% 、 37.7$ 月でDM群が長期であっ た。LM群の治療と生存期間について検討した。再発 肝転移は32.1力月で、 $\mathrm{H}(+) 11.5$ 力 月より有意に長かっ た。 $\mathrm{H}_{1}$ or $2 \mathrm{P} 0$ の肝転移切除例 (相非治) は32.5力月、 非切除例は8 月であった。 $\mathrm{H} 3$ の原発巣切除例は 8.6 力 月、非切除例は2.2力月であった。再発肝転移に肝切、 orTAE, orPEIを施行した5例中4例が生存中で、平均37力 月であった。(結語) (1)肝転移を来す胃癌は腹膜転移 を来す胃癌との比較では、高秢で、サイズが小さく、 Borrmann2型、深達度ssまで、分化型、INF $\alpha$ 、ly2まで が有意に高率であった。(2)(1)の両者の予後に差はみら れなかった。(3)血行性遠隔転移を来す胃癌の生存期間 は3年強であった。(4) H2までの肝転移には同時性、異 時性を問わず、積極的な治療、H3には可能な限りの原 発巣切除が延命につながる。
示-20 内視鏡的治療後に開腹切除術を必要とし た胃癌症例の検討

福井県立病院外科
細川 治、桶下徹哉、津田昇志、渡辺国重
谷川 裕、白崎信二、山脇 優、服部昌和
〔目的〕

胃癌に対する内視鏡的治療において、術前に癌巣の 深達度、範囲、癌巣内潰㾤の有無などを診断すること は重要である。そしてそれにも增して、治療後に内視 鏡を用いて、癌の遗残再発や他部位での癌発生を見い だすことが重要である。そこで当科において内視鏡的 治療後に開腹切除術を必要とした胃癌症例を中心に検 討を行った。

【対象と方法)

1977年から1993年までに当科で内視鏡的治療を行っ た早期胃癌症例は40例である。内視鏡的治療後に原則 として、 3 か月目、 6 か月目、12 12 月目、以後 1 年お きに内視鏡を用いて追跡した。40例のうち6例が開腹 切除術を必要とされた。さらに他機関で内視鏡的治療 を受けたのちに、当科で開腹切除術を行った症例が 3 例存在する。これらの症例を対象として、追跡方法、 開腹切除に至った理由を含めて、臨床病理学的検討を 行った。

(成績)

(1)内視鏡的治療後に開腹切除術を必要とした9例の 治療手技は内視鏡的切除 7例 (Polypectomy 3例, Stri p biopsy 4例) 、レーザ治療 1例、Polypectomy とレ 一ザ治療の併用 1 例であった。

(2) 9例はすべて分化型腺癌であり、癌巣径は1例を 除いて $2 \mathrm{~cm}$ 以内であり、肉眼型は隆起型 7 例、陥凹型 2例であった。術前の推定深達度は $\mathrm{m}$ 癌であった。

(3)開腹切除を必要として理由としては微小 II c が sm 浸潤癌であったもの1例、内視鏡的治療後の追跡で癌 の遺残が証明されたもの6例、他部位に新たに癌が発 生したもの2例であった。

(4)内視鏡的治療から開腹切除術までの期間は11日か ら 5 年 5 か月、平均 1 年 6 か月であった。この期間に 1回から7回、平均 2.7 回の内視鏡的検査を受け、最 終的に開腹切除術が必要とされた。

(5)複数回の内視鏡的追跡にもかかわらず、癌の遺残 が各々 4 年 2 か月後と 5 年 5 か月後まで発見が遅れた 2 例が存在した。また 1 年の内視鏡検査間隔で他部位 に進行癌が見いだされた1例が存在した。

(まとめ)

胃癌の内視鏡的治療後には、癌の遗残と他部位に癌 が発生する危険性を考虑にいれて、丹念に全胃を検索 する必要がある。追跡期間は可能な限り長期にわたる 必要があり、また間隔は6か月おきが望ましいと考え られた。 
新潟県立坂町病院 外科

福田稔, 渡辺和夫

目的; 胃切除後におこる骨障害（骨折，腰痛，手足 のしびれ，関節痛等）は意外に多いにあかかわらず， 未だに本格的な調查，治療は行なわれていない。我々 は昭和 49 年より, 胃切除後の骨障害について研究報告 を行なってきた。今回当病院において約 3 年間の調查 で興味ある結果が得られたので報告する。

方法; 症例は, 胃切除後 2 年以上外来で経過を調查 出来た 50 例を対象とした。年齡は，43才〜87才でそ の平均は 70.1 才。男性は35例，女性は15例であった。 術式でみると胃全摘12例，ビルロートI法33例，ビル ロートII 法 3 例，その他 2 例であった。術後経過年数 は 2 年〜 22 年でその平均は 5.9 年であった。乙れら症 例に骨塩量（D法，1984骨代誌）を測定するととあに 血清カルシューム $(\mathrm{Ca})$, 燐 $(\mathrm{P})$, アルカリフォスフ アターゼ (Al-p) 值を測定し, 術後の骨障害について 調査を行った。50例中 ビタミンD (VitD)，カルシ トニン (S-CT) 併用例は39例，無治療例11例であった。 また骨折を来した 2 症例と副甲状腺機能六進症の 1 症 例について，その治療経過を報告する。

結果; 胃切除後に症状があるために治療を要した症 例は，平成 2 年の時点では $60 \%$ あったが，今回は78\% であった。また胃切除後に骨折を来した症例は 4 例（ 896) あったが，いずれの症例す骨塩量は低值を示し $\mathrm{Al}-\mathrm{p}$ 值む 1 例を除き $180 \mathrm{IU} / \mathrm{L}$ 以上を示していた。 また副甲状腺機能穴進症例す2 例認められ，手術之治 療により軽快している。平成 4 年度までは VitD 剂 のみの治療例は 8 例あったが Al-p 值の低下が認められ ず骨折に至る症例が出現したため，平成 5 年度よりは， 主にVitDとS-CTの併用療法を行った結果, 少数例を除 き，Al-p值の下降をみることができた。次にAl-p值と 骨塩量の関係を調べてみた。骨塩低下症例ではその平 均値は $225 \mathrm{IU} / \mathrm{L}$ 骨塩正常症例は $151 \mathrm{IU} / \mathrm{L}$ であり両 群間に有意の差が認められた。（ $\mathrm{P}<0.0008 ）$

結語；1)胃切除後におこる手足のしびれ, 腰痛の症状 を術後早期よりチェックする必要がある。（手術時 年齢が高い症例，女性，牛乳を飲まない症例は注意）

2) 血清 Ca，P，Al-p 値を術後経過を追って観察する 乙とが大切で，特に Al-p值が上昇傾向 ( $180 \mathrm{IU} / \mathrm{L})$ 以 上の時は注意を要する。

3)胃切除後の骨障害の治療にはVitDのみでは効果 が少なく S-CT, Ca 剂の併用が有効である。

\section{示-22高撂者（75才以上）胃裙手術例の検討}

山田赤十字病院外科

中野英明、武藤利茂、大檽直樹、楠田司、上原伸一 、林化席、村林㑊二

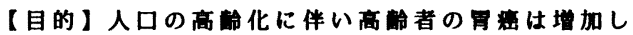
ている。今回、当科で開腹手街を施行した高战者（75

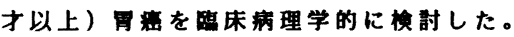

【対象及び方法】运去11年間に当科で開腹手術を施

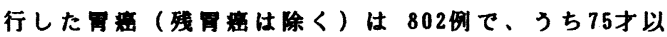

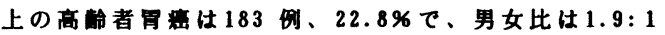
であった。183 例の高䤅者用数のうち、80才以上は51 例、27.9\%で、男女比は1.8:1で、取高年令は92才男

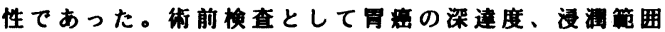
やリンバ節㬐大を模索する目的で、1985年より内視鏡 的超音波診断 (EUS)を施行し、また内視篭的に切除可

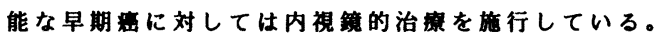

【結果】1)併存する基磁疾患の頪度：街前より55.3 \%に心、肺、脂血管、肝なとに併存疾患を認めたが、 特に循環器疾患の合併が36.5\%と高率であった。2)手 術: (1)切除率: 183 例中切除洌は 151 例、82.5\%で、 非切除因子としてはP(十)が最も多かった。切除例の治 切除率は70.2\%であったが、80才以上では50.0\%と

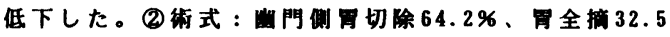

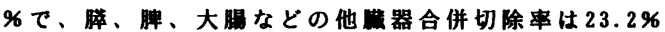
であった。(3)リンバ節郭清：高踰者に対してはD バ節郭清を基本としているが、術前のEUSにて梁達度 $\mathrm{m}$ と判定され内視籍的治療の暗応のないものに対して は D 、一般状態 (PS) が良好で治彻除が可能な進行

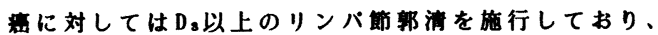
$D_{1} 17.8 \% 、 D_{2} 63.0 \% 、 D_{3}$ 以上17.0\%であった。3)病理

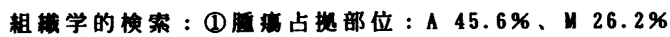

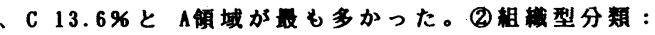
pap $21.6 \%$ 、tub $29.4 \% 、 t u b_{2} 17.0 \%$ 、por $17.0 \%$ 、 sig 11.1\%で高分化腺哣が高率であった。(3)組樴学的 深達度：m16.3\%、sw17.7\%、pw12.2\%、ss17.0\%、 se以上 $36.7 \%$ て、早期呈の頻度は34.0\%であった。肉

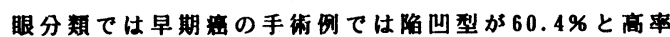
て、進行福では 4 型が低率であった。(4) stage（旧分 類) : I $33.7 \%$ 、II $7.7 \%$ 、III $23.2 \%$ 、IV $35.4 \%$ て 、 80才以上では I 23.5\%、IV 47.1\%であった。また早期

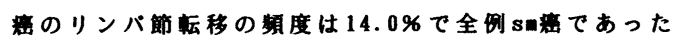
。4)予後： stage I、IIは良好で10年生存例もみられ 再発死亡は少数例であった。 stage四では郝前のPSが 良好なものでは抬大リンバ節䢀清により長期予後が期 待されるものもあるが、stageIVの予後は不良であっ た。在院死亡は 27 例、14.8\%て、うち stageIVの単開 腹や吻合術㢈行例が 15 例と多く、切除例の在院死亡は 街前PS不良例、非治疾切除例、胃全摘例に多かった。

【結語】高龄者周密は、高分化型て A 領城に多く、 stage I、IVの割合が多かった。また、高䀫者は併存 する基磁疾患を高率に認めるが、術前に EUSを用いて

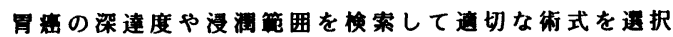
することにより治切除例ては長期生存が得られた。 
$388(1560)$

長崎大学第二外科、同救急部 $*$

小関一幸、浦 一秀、井沢邦英 $*$ 、兼松隆之

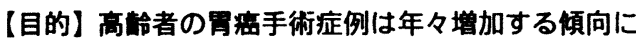
あるか、術後合併症の類度は高く、手術適応や切除術 式の選択の検封は全要な課題である。そこで今回、当 教室で経挽した 80 歲以上高龄者男症手術症例につい て、密の進行度、リンパ節郭满度、治虑度における予 後及び合併症の面から検討した。

【対象と方法】1980年1月より1993年12月 まてに教室で経験した胃癌症例は 650 例で、80歳 以上の高秢者胃㾇は 46 例であった。このうち 37 例 （男性 17 例、女性 20 例） $80.4 \%$ に切除術が行 われた。

【結果】予後: 進行度別症例数は、期 8 例、川期 5 例、 川I期 14 例、IV期9例（不明 1例）であった。術死を 除<5 年生存事は、澌 $80 \%$ 、唭 $75 \%$ 、期期 20 \%、N期0\%であり、80煘末满切除症例での5 年生 存事 $85 \% 、 77 \% 、 59 \% 、 16 \% に$ 比べてIII、IV 期では予後不良であるが、、、期ではそれほど差を認 めなかった。リンパ節郭清度別症例数はD01 1例、D 113 例、D21 2 例、D 1 例で、その5 年生存率は、 Do0\%、D138\%、D24 7\%であった。80歳未满 切除例での、D02 2\%、D157\%、D267\%、（D $360 \%)$ と比べてDoが特に予後不良であった。治痓 度別症例数は、根治度A 11 例、根治度B 10 例、根 治度C 16 例で、5年生存率は、A群 $86 \% 、 B$ 群 4 3\%、C群0\%であった。 80 歳末满切除例の 5 年生 存率は、A群 $79 \%$ 、B群 $54 \%$ 、C群0\%であり、 特に差はなかった。術後合併症 : 進行度別合併症発生 頻度は、川期では０例（O\%）、川期11例 (76\%)、 IV期4例（4 4\%）であり、III、IV期には高頻度に発 生し、心不全、呼吸不全が多かった。リンパ節郭清度 別では、D06例 (5 5\%)、D16例 (46\%)、D2 以上 11 例 $(38 \%)$ とリンパ節郭湆の程度と術後合 併症には差は認めなかった。治症度別合併症発生頪度 はA群 1 例 (9\%)、B群6例 $(66 \%) 、 C$ 群 9 例 （56\%）であり、A群に比較してB、C群症例の合 併症は高率に発生した。

【結論】80歲以上の胃癌手術症例では、リンパ節郭 洤度別での合併症発生に差はなく、D2手術で良好な予 後が得られており、充分なリンパ節郭清ができ根治度 Aが可能な症例には䅡極的に手術をおこなうべきであ る。一方III,IV期でのDo症例は、合併症発生率が高く予 後も非常に悪い。かかる症例は手術適応に慎量を期す ベきと考える。
示-24

日消外会誌 27 巻 6 号

高噛者胃癌の治療上の問題点と対策

東京都立駒込病院外科

荒井邦佳，北村正次，岩崎善毅

【目的】近年, 増加傾向にある高齢者胃癌の特徵を解 析し，手術治療上の問題点と対策について検討する。

【対象と方法】1975年4月から1992年12月までに

扱った胃癌切除例は2622例である。75歳以上 [高齢 群]は 320 例 $(12 \%)$ であり，これらを対象として高 齢者胃癌の特徵を検討したが，このうち8 0 歳以上は 106 例 (4\%) を占めていた。一方, 胃癌全症例の平 均年齢が60.9歳, 中央値62歳であることから，60歳 以上65歳未満の症例 [平均群] 391 例を対照として比 較した。

【結果】性比, 占居部位, リンパ節転移の有無および 転移個数には差を認めなかった。高柃群と平均群（高 齢群/平均群）の深達度は $\mathrm{t} 1: 28 \% / 34 \%, \mathrm{t} 2$ : $35 \% / 32 \%$, t $3: 30 \% / 28 \%$, t $4: 7 \% / 6 \%$, 組織 学的ステージはI : $41 \% / 44 \% \quad$ II : $13 \% / 10 \%$, III： $26 \% / 21 \%$ ＩV : $20 \% / 25 \%$ ともに差を認めなかっ た。しかし，組織型では，分化型癌(pap,tub1,t ub2) の頻度が高路群に有意に多く（69\%/52\%:p $<$ $0.01)$ ，多発癌の頻度も高齢群 (28\%) が平均群 （16\%）に比較し多かった $(p<0.01)$ 。

手術治療では，胃切除の簕囲に差はなく，他臟器合 併切除の頻度も 80 歳以上では30\%ट少ないものの, 高 齢群 $(44 \%)$ と平均群 (43\%) には差はなかった。し かし，郭清度では高路群にD $0 ， \mathrm{D} 1$ が多く（D0+D 1 の頻度 : $51 \% / 26 \%: p<0.01)$ ，根治 C の頻度 は差がないものの根治 Bが相対的に多かった。

食道浸潤癌は，高柃群2 7 例（ $8 \%$ ），平均群 40 例 (10\%)にみられたが，縦隔リンパ節転移率はおのお の16\%，21\%であり高齢群での転移率が低かった。縦 隔への到達経路では，最近の高柃群では左開胸腹や胸 骨綎切開法が減少し，侵警の少ない横隔膜切開法を 選択する例が增加していた。

高齢群の基礎疾患の頻度は約 $60 \%$ 高率であったが， その死因は平均群に比較し，他病死・他癌死が多く

（全症例中の頻度：17\%/6\%)，術死（1.9\%／ $1.3 \%)$ および在院死亡 $(0.3 \% / 0.8 \%)$ には差がな かった。また，根治Cを除く 5 年生存率は，高撂群 $44.8 \%$ ，平均群68.3\%であったが，相対生存率はおの おの $66.7 \%, 70.6 \%$ \%でり有意差を認めなかった。

【結論】1，高齢者胃癌は平均年路層の胃癌に比較し， 組織型で分化型癌が多く，多発の頻度が高い。また， 食道浸潤癌の頻度に差はないが，縦隔リンパ節転移率 は低い傾向であった。

2. 基礎疾患を有する率は高いが，過大な侵㱍を避け 根治切除に必要な最低限の郭清を行うことにより手術 関連死を回避でき，比較的良好な予後が得られる。 
示-25 高路 (80歳以上) の胃癌患者の外科治療 に関する検討

\section{佼成病院外科}

森越栄太, 佐藤薰隆, 向井佐志彦, 為我井芳郎, 渡 辺一彦，渋谷純一，大坂信太郎，平井恭二，亀谷肇， 南部弘太郎

〔目的〕過去14年間における超高秢者胃癌症例を手 術成績，合併症について検討し，治療方針について考 察する。

〔対象と方法]1980年から1993年までに当科に入院 し，外科的治療を受けた胃癌は 767 例あり，うち80歳 以上の48例 (6.2\%) を対象にした。内訳は男性27例, 女性21例で，年齢は80歳から88歳で，平均年秢は82.8 歳であつた。これらの術前術後を分析し，外科治療の 問題点を検討した。

[結果](1)病期 ; stage I 15例，II 2 例，III 12例， IV 19例。郭清度；R0 8 例，R1 9 例，R2 30例，R3 1 例。手術術式； 7 例が，短開腹もしくは胃空腸吻合。 10例に，胃全摘術。31例に胃亜全摘もしくは噴門側切 除術を施行した。(2)術前合併症 ; 評価不能の 1 例を除 <47例を検討すると，23例は重要臓器に機能障害無く， 心機能障害は18例，堅機能障害は 6 例，呼吸機能障害 は 5 例, 脳梗塞の既往を 2 例に認めた。(3)手術成績と 術後合併症；手術例48例中，術死は 5 例 ( $12 \%)$ であ り，3 例が術後40日以内に入院死亡した。評価可能な 47例のうち18例にのべ24の術後合併症の発生を見た。 多いものは精神不穞 5 例, 肺炎・無気肺, 腹腔内感染, 心不全，不整脈，腎不全が 3 例ずつあつた。入院死亡 した 8 例のうち， 6 例が心，肺，堅のうち 2 つ以上の 術後合併症を併発していた。入院死亡した 8 例とそれ 以外の39例につきその要因を分析すると，年踰は平均 $82.9 \pm 1.4$ と $82.5 \pm 2.2$ と差はなかつた。病期では 3.5 \pm 1.1 と $2.4 \pm 1.3$ と死亡群で高いが $(\mathrm{p}<0.05)$, 郭清 度 $\mathrm{R}$ は $0.8 \pm 0.7$ と $1.6 \pm 0.8$ でむしろ死亡群で低かった $(\mathrm{p}<0.01)$ 。 術前の心機能，呼吸機能等の障害臟器 の数の平均は死亡群で $2 \pm 0.8$, 他では $0.56 \pm 0.7$ と, 死亡群で術前合併症の多い傾向があつた $(\mathrm{p}<0.01)$ 。 術後合併症を起こした例で合併症数別の死亡率を見る と, 合併症が $3 つ （ 2$ 例 ）では入院死亡率 $100 \%, 2$ つ( 8 例)では $50 \% ， 1 つ$ ( 14 例)では $14 \%$ と合併症 数が多いほど死亡率が高い傾向があった。癌の進行度 と合併症発生率の関係を見ると，II 期以下では $12 \%$

( $2 / 17)$, IIII H $_{58} \%$ ( $\left.7 / 12\right)$, IV 期47\% $(9 / 19)$ て あつた。郭清度と合併症との関係を見ると, R0手術で は合併症が38\% ( $3 / 8$ )に発生し，R1では44\%(4/9), R2では36\%(11/30)であつた。

〔 結語]入院死亡した症例は術前の臓器障害の数が 多い傾向があつた。病期の進んだ症例でかつ臟器障害 数が多い場合, R0orl 手術でも危険が大きかつた。
示-26高数者胃癌における術前, 術後合併症よ りみた術式の選択

国立がんセンタ一中央病院外科, 東病院外科 * 片井均, 丸山圭一, 笹子三津留, 佐野武, 岡島一雄, 木下 平*

[目的]人口の高秢化に伴い 80 歳以上の男癌患者数は 増加している。高数者は術前に呼吸器, 循環器などに 障害を有することが多く、手術に際して十分な配感が 必要である。今回はとくに、合併症の面から胃癌好発 年龄の胃癌症例との対比を行い、その術式を检討した。 [対象と方法] 1971年から1990年までの 20 年間におけ る胃癌 (腺癌) 症例は 4740 例であり、80歳以上は 112 例 (2.4x)であった。これらを高柃者群として 50-69歳 (2664例：56.2\%)の胃癌症例と比較検討した。

[成績] 術前合併症は高齢者群の76.8\%にみられた。 対照群では53.1\%であった $(p<0.001)$ 。術前合併症の内 訳は高柃者で循環器疾患 (30.4\%), 貧血 (21.4\%), 呼吸器 疾患 (13.4\%)の順で、対照で循環器疾患 (15.4\%), 楉尿 病 (11.0\%), 貧血 (11.0\%)であった。術後合併症の発生 率は高齢者で $32.1 \%$ ，対照で27.9\%であった（p<0.05）。 術後合併症は、高铃者で呼吸器疾患 $(8.0 \%)$, 腹胿内感 染症 (7.1\%), 縫合不全 (5.4\%)の順に頻度が多く、対照 で腹㓐内感染症 (10.8\%)，縫合不全 (5.8\%), 肝障害 $(4.2 \%)$ であった。高齢者と対照の間に病期分布の差はなかっ たか、切除率は高齢者で 100 例 (89.28)，対照で 2512 例 (94.3x)であった $(p<0.05)$ 。郭清程度は高数者の $D_{2}$ 郭 清 51例 (45.5\%)に対して、対照は1936例 (72.7\%)であっ た $(p<0.001)$ 。胃切除篹囲之術後合併症の発生率を検 討した。幽門側胃切除では高齢者と対照で差がなく、 それぞれ 23.4\%,20.4\%であった。全摘では対照の発生 率 47.08 に対して、術前に合併症を有する高柃者では 72.08と高率であったか、それがないと28.6\%と低下し た。標準術式である $\mathrm{D}_{2}$ 郭清を行うと対照での術後合併 症発生率は27.6\%であった。これに对して、術前合併 症を有する高数者にD2郭清を行うとその発生率は $38.5 \%$ 上高く、合併症がないと $16.7 \%$ と低かった。合併切除 例での高柃者の術後合併症は術前合併症の有無で58. $3 \%$

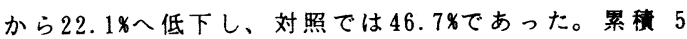
年生存率で両群の成績を比較すると高数者で $32.6 \%$, 対照で61.1xであった。手術直死を除く術後 5 年以内の 死因は高齢者で他病死が $42.3 \%$ をめ、対照の7.5\%よ り高率であった $(p<0.001)$ 。さらに高峆者では術後 1 年 以内の他病死が全 112 例中 11 例に認められた。

[結論]高秢者では術前, 術後の合併症の頻度が対照 より高率であったか、術前合併症を有さない症例に対 しては標準術式が可能であり、術前に合併症を有する 患者には症例に応じた縮小手術が適応されるへきと考 えられた。また、高粭者では術後早期の他病死も多く 術式の選択にはこれも十分考虑すべきと考えられた。 
示-27

高齢者の胃癌手術における問題点と手術 方針に関する検討

\section{札幌医科大学第一外科}

浦 英樹, 伝野隆一, 亀嶋秀和, 鶴間哲弘, 向谷充宏, 及川郁雄, 佐々木一晃, 戸塚守夫, 平田公一

【目的】相対的な若年層との比較により高齢者の胃癌 手術における周術期の問題点を明らかにするととむに, 手術方針に関して若年層と差を設けるべきか否かにつ き検討したので報告する。

【対象と方法】1975年 1 月から1992年12月までに当科 で切除した原発胃癌 995 例を対象に，60歳未満を $\mathrm{A}$ 群 (484例), 60歳以上75歳未満をB群 (443例), 75歳以上 をC 群 (68例) と分類し, 他疾患併存率, 術後合併症発 生率, およびそれらの相互関係や手術術式との関連性, 術後在院日数などについて群問比較を行なった。

【結果】(1)他疾患併存率は A群 $21.3 \%, B$ 群 $39.3 \%$, $\mathrm{C}$ 群 $60.3 \%$, 乙のうち 2 疾患以上の併存率は $\mathrm{A}$ 群 $5.4 \%$, B群 $14.4 \%$, C 群 $27.9 \%$ と年齢層が高いほど高率であ った $(p<0.01)$ 。併存疾患の内訳は各群間とも高血代, 糖尿病, 心疾患が上位 3 疾患を占め, 肺疾患は $\mathrm{B}, \mathrm{C}$ 群 で 4 位，A群では 5 位であった。(2術後合併症発生率ば A群 $20.7 \%$, B群 $26.4 \%$, C群 $25.0 \%$ と差を認めなか った。合併症の内訳は各群とも縫合不全が最も多く,

$\mathrm{A}$ 群 4.5\%, B群 8.8\%, C群 10.3\%で, B, C 群の縫 合不全発生率が高い傾向を認めた。 B，C群では次い で肺合併症が多く，それぞれ 5.2\%，7.4\%であり，A 群 (2.9\%) と比較し高率であった。(3)併存疾患を伴わ ない症例の合併症発生率は A 群 $17.8 \%, \mathrm{~B}$ 群 $23.0 \%$,

C 群 $11.1 \%$, 何らかの併存疾患を伴う場合ではA群 31.1 \%, B 群 $31.6 \%$, C群 $34.1 \%$ であり，併存疾患が術後 に及ほす影響は, 数值的にみるかぎり年齢層を問わず 一様であった。(4)切除術式別に合併症発生率を比較す ると, 幽門側切除では A 群 $16.4 \%, \mathrm{~B}$ 群 $18.6 \%, \mathrm{C}$ 群 $26.9 \%$, 胃全摘（噴切を含む）ではA群 $27.7 \%, \mathrm{~B}$ 群 39.9\%, C 群 $18.8 \%$ であり, A, B 群は全摘例の合併 症発生率が有意に高かったのに対し, C群では切除術 式による差を認めなかった。また, リンパ節郭清をD 以下にとどめた症例の比率はA 群 $16.9 \%$, B 群 $19.2 \%$, C群 $35.3 \%$ と 群が有意飞多かったが, D2 以上の郭清 例における合併症発生率は A群21.9\% (88/402), B群 28.2\% (101/358), C群25.0\%（11/44）と差を認めな かった。(5)合併症 (一)例の平均術後在院日数は A群 29 日, B群26日, C群26日, 合併症 (+) 例ではA群45日, B群52日, C群41日と各群間で差を認めず, また直死・ 在院死亡率屯A群 $2.3 \%$, B 群 $3.4 \%$, C 群 $2.9 \%$ と差 を認めなかった。

【結論】高㱓者は基礎疾患の併存が多いが, 合併症発 生率や回復に要する日数などは他の年龄層と大差なく, 積極的な根治手術を心がけるべきと考えられる。
示-28高齢者胃癌手術の術後合併症とその対策 一胃全摘術と幽門側胃切除術についてー

大阪医科大学一般 - 消化器外科

磯崎博司, 岡島邦雄, 中田英二, 一八名 正, 野村 栄治, 藤井敬三, 泉信行

【目的】近年, 胃癌手術は比較的安全となっている が, 高龄者（75歳以上）に対しては術前・術後の特別 な配虑が必要である。今回, 高踰者胃癌手術の術後合 併症の特徴とその対策を検討した。【対象と方法】 過去14年間の胃癌手術 1751 例中，75歳以上高齢者の胃 全摘30例と幽門側胃切除104 例の計 134 例を「A 群」 として, 術前状態, 術後合併症と在院死亡原因（癌死 を除く）を検索し，合併症対策を検討した。なお，60 歳未淦の胃全摘191 例と幽門側胃切除509 例の計700 例を対照群「C群」としてA群と比較梌討した。きた 術前の藏器所見は，心 (CTR ミ50\%, ECG 異常), 肺 ( $\% \mathrm{VC}<80 \%, \% \mathrm{FEV}_{1} .0<70 \%$, 胸部X-P 肺野異常), 肝 (ChE $<200 \mathrm{U} / \mathrm{L}$ ), 堅 (PSP120 分値 $<55 \%, \mathrm{BUN} \geq 20 \mathrm{mg} / \mathrm{dl}$, Creatinine $1.5 \mathrm{mg} / \mathrm{dl}$ ) を異常とした。【成樍】1)術 前状態: 術前臟器異常所見率は $\mathrm{A}$ 群, C 群それぞれ, 心 $(68 \%, 44 \%)$, 肺 $(64 \%, 29 \%)$, 肝 (69\%,23\%), 腎 $(41 \%, 12 \%$ ) とA群に高率であり，血中リンパ球数 $(1677,2225 /$ $\mathrm{ml})$ とアルブミン值 $(3.4 .3 .9 \mathrm{mg} / \mathrm{dl})$ は両群間に有意 差を認めた $(P<0.0001)$ 。2)術後合併症と在院死亡率 ：術後合併症発生率( 創感染などすべてを含む) はA 群 ( 全摘 $60 \%$ ，幽切 $40 \%), C$ 群 ( 全摘 $44 \%$ ，幽切 $23 \%$ ) と A 群に高いが, 艂合不全発生率には差がなかった。在 院死亡率は $\mathrm{A}$ 群( 全摘20.0\%, 幽切12.5\%), C 群 (全摘 5. 8\%，幽切 $1.2 \%$ ) であり， A群は C 群より有意に高率 であった（全摘，幽切とも）。なお，胃全摘群全体の 死亡率は幽切群のそれより有意に高率であった。

3 ）在院死亡原因：主な死亡原因は，A群では, 全摘 群は死亡6 例中, 肺炎2 例, 心不全2 例であり, 幽切 群は死亡13例中, 肺炎 6 例, 心不全 2 例であり, 呼吸 循環器の合併症( とくに肺合併症) が多く，厳重な術 前・術後管理が不可欠と考えられた。これに対し，C 群では, 全摘群では䋖合不全や膆瘦を契機したものが 多く, 幽切群では敗血症や消化管出血などであり, 呼 吸循環器の合併症による死亡例は少なかった。なお, 槰合不全発生例の死亡率はA 群80\%(4/5), C 群 $27 \%$ (7) 26）であり，高柃者では一度縫合不全が発生するとそ の死亡率は高かった。【結語】高粭者胃䆆手術での最 大のポイントは呼吸循環器系の合併症防止である。な かでも肺合併症対策が重要で, 術前・術後の呼吸訓練 やトラヘルパーの㨂入に加え, 肺合併症が予想される 症例に対しては予防的気管切開を考虑すべきである。 われわれは最近，経鼻管を避けることと万一の䋖合不 全に備えて，胃全摘例では举上空腸脚に，幽門側胃切 除例では残胃に腸瘻を造設して，好成績を得ている。 
示 -29 80 歳以上高龄者胃癌の手術成績と問題点 及びその対策

大阪府立成人病センター外科

平塚正弘、古河 洋、岩永 用、中野博史、 中森正二、大東弘明、亀山雅男、佐々木洋、 甲 利幸、石川 治、小山博記、今岡真義 【目的】 80 歳以上高龄者の胃癌手術成績と問題点及び 対策を检討する。

【対象・方法】1993年までに大阪府立成人病センター で開腹手術をした 80 歳以上の胃癌52例を対象とした。 併存疾患、術前検查成績および手術侵皎と術後合併症 との関連を検討した。手術病理所見は胃癌取扱い規約 11版に従い、生存率はKaplan-Meier法を用いた。

【結果】年代別症例数 [( ) 1855 歳以上 $]$ 1978年まで 4例 (0\%) で、その後 5年每に 8例 (0\%)、16例 $(19 \%)$ 、 24例（33\%）と高龄者が增加した。

(1)湢床病理所見を 80 歳未満と比較した（80歳以上 $/ 60$ ７9歳1466例）：男女比 $2.5 / 2.8$ 、早期胃癌率 $56 \%$ ／ $39 \%$ 、切除率 $94 \% / 90 \%$ 、切除例中根治手術率 $84 \% /$ $92 \%$ 、胃全摘の占好率 $24 \% / 28 \% 、 \mathrm{R}_{2}$ 以上郭清 41 $\% / 68 \%$ であり、 80 歳以上は早期胃癌が比較的多く、 郭清程度も比較的低いが、胃全摘には差がなかった。 (2)術後合併症 : (1)術前僧存疾患之の関連；切除 49 例の うち併存疾患 (+) 23例（高血圧18例、糖尿病 3例、 心疾患 4例、呼吸器疾患 2例、慢性肝炎 1例、脳梗塞 1例）中、術後合併症は 7例 $(30 \%$ 、繾合不全 1 例、 創感染 3例、堅機能障害 2例、旰機能障害 1例) にみ られたが、（一）例は $12 \%$ （精神障害 2 例、長期の不 定愁訴 1例) であった。糖尿病と高血压の併存例に繾 合不全がみられ、後に心不全で在院死した。(2)術前検 查成績との関連；堅機能検查で術前血清クレアチニン (Cr) 值が1. 5 以上で術後に障害がみられ、Cr1.8 の症 例はネフローゼ症候群を合併し退院まで96日、Cr1.9 では術後BUN 88，Cr 9.5まで上昇し退院まで71日要し た。術前Cr值1.8 以上は危険である。(3)手術との関 連; 幽切36例では、創感染 2例、精神障害 1例、不定 愁訴 1例の計 4例（11\%）であったが、胃全摘12例で は 6例（50\%）と多く、繾合不全、堅機能障害、肝機 能障害など重篤であった。出血量では $500 \mathrm{~m} 1$ 以上で堅 機能障害例が出現し、1000m1以上は 2 例でともに重篤 な合併症が発生した。

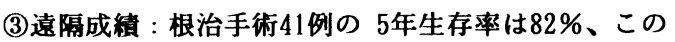
うち胃全摘10例では $80 \%$ であり、80歳未満例の $68 \%$ 、 $56 \%$ よ良好であった。

【まとめ】80歳以上高齢者においても、胃全摘術は少 なくなく遠隔成績も良好である。ただ、重篤な術後合 併症もあり、その適応は重篤な併存疾患がなく、血清 クレアチニン值1.7 以下とし、吊り上げ鉤と器械吻合 により、低出血量で終えることが重要である。
示-30食道静脈瘤直達手術の奇静脈血流量に 対する影響一とくに長期子後との関連について

東京大学第 2 外科

國土典宏、佐藤直夫、野村幸博、皆川正己、橋本 雅司、上寺祐之、万代恭嗣、三條健昌、出月康夫

門脈圧六進症における上行性の側副血行路の定量 的な指標として奇静脈血流量(AzBF)が有用であるが、 今回、直達手術前後の AzBFの変化を、とくに静脈 瘤の再発との関連において検討を加えたので報告す る。【対象および方法】直達手術の前および 1 か 後にAzBF、補正閉塞肝静脈圧(HVPG)、心拍出量 (CO)などの血行動態の評価を行なった門脈圧元進症 29例 (経腹食道離断21例、経胸食道離断3例、Hassab 手術 5 例)のうち術後 2 年以内にF 2 の静脈瘤の再発が みられ硬化療法を施行した3例(再発群) と、2年以上 再発を認めずにfollow-upされている16例(非再発群) について比較を行なった。AzBFはWebsterカテーテ ルを奇静脈内に挿入し、局所熱希釈法によって測定 した。HVPGは8Frバルーンカテーテルを右肝静脈 内に挿入し、自由肝静脈圧と閉塞圧との差によって 求めた。COはSwan-Gantzカテーテルによって测定 し、AzBFのCOに対する比 $(\mathrm{AzBF}(\%))$ を算出した。

【結果】再発群の再発までの期間は15-24か月(平均 21 か月)で、1例で再発時に細小肝癌を合併していた。

\begin{tabular}{|c|c|c|c|}
\hline & & 非再発群 $(\mathrm{n}=16)$ & 再発群 $(\mathrm{n}=3)$ \\
\hline 男女比 & & $12 / 4$ & $2 / 1$ \\
\hline 平均年龄 & & 56.8 & 55.0 \\
\hline 原疾患 & & $\mathrm{LC14}, \mathrm{IPH1}, \mathrm{EHOI}$ & $\mathrm{LC} 2, \mathrm{IPH1}$ \\
\hline $\mathrm{AzBF}$ & 術前 & $435 \pm 40$ & $245 \pm 73$ \\
$(\mathrm{ml} / \mathrm{min})$ & 術後 & $352 \pm 35^{* *}$ & $283 \pm 67$ \\
\hline $\mathrm{AzBF} / \mathrm{CO}$ & 術前 & $8.47 \pm 0.99$ & $4.48 \pm 1.88$ \\
$(\%)$ & 術後 & $6.02 \pm 0.76^{* *}$ & $5.26 \pm 1.37$ \\
\hline $\mathrm{HVPG}$ & 術前 & $13.8 \pm 0.9$ & $17.5 \pm 0.5$ \\
$(\mathrm{mmHg})$ & 術後 & $12.3 \pm 0.6^{*}$ & $17.5 \pm 2.5$ \\
\hline
\end{tabular}

(mean $\pm S E,{ }^{*} p<0.05, * * p<0.01$ vs. 術前值, LC:肝 硬变, IPH:特発性門脈圧充進症, EHO:肝外門脈閉塞)

この他、術後4年以上を経た遠隔期に再発のみられ た2例の再発時のAzBFは術前値に比べ平均 $46.5 \%$ 増 加していた。【まとめ】直達手術後の長期的検討に おいて、食道静脈瘤の再発がみられなかった症例は 手術によるAzBFおよびAzBF/COの減少が有意であっ た。再発例は症例数が少ないが、全例手術による両 指標の減少がみられなかった。HVPGは再発群が非 再発群に比べて高い傾向にあった。術後遠隔期の再 発例では再発時のAzBFが手術前の值に比べて大き く増加していた。直達手術による侧副血行路のredistribution後に奇静脈系の関与が減少しない症例、 門脈圧の高い症例は再発のriskが高いと考えられた。 
示-31 T I P S の臨床的有用性および全身門脈 血行動態におよぼす影響について

東京女子医科大学附属第二病院外科 放射線科*

我妻美久, 成高義彦, 島川 武, 勝部隆男,

三浦一浩, 渡辺俊明, 平井雅倫, 石川信也, 矢川裕一, 小川健治, 捤原哲郎, 遠田 譲*

【目的】われわれは肝硬変に伴う難治性食道静脈瘤 や難治性腹水に対して, 経皮的肝内門脈静脈短絡術 （以下T I P S ) を 3 症例に施行した。今回はその臨 床的有用性, 全身血行動態, 門脈血行動態におよほす 影響について検討したので報告する。

【対象之方法】症例 1 は58歳の男性 child Cの肝 硬変, 吐血を繰り返す難治性静脈瘤に対して, 症例 2 は69歳の男性, 症例 3 は64歳の男性, いずれも child Cの肝癌合併肝硬変, 保存的治療に抵抗する難治性腹 水に対してTI P Sを施行した。T I P Sの方法は Rosch-Uchida の経頸静脈門脈アクセスセット (Cook 社製)を用い, stent には径 8 mmおよび10mmのexpandable metallic Z-stent を使用した。そして全身血行動態 への影響については，鎖骨下静脈より挿入したSwan$\mathrm{Gan} z$ カテーテルにて平均肺動脈圧 (PAP), 肺動脈柢 入匟 (PWP), 中心静脈圧 (CVP), 熱希釈法による 心拍出量 (CO)をもとに 1 回拍出係数 (CI ) を測定し た。また，暁骨動脈に㨂入した動脈圧測定用カテーテ ルにて平均動脈圧 (BP) と脈拍数 (PR) を測定した。 門脈血行動態については超音波ドプラにより門脈本幹 の平均流速, 断面積, 平均流量を測定し, 榃血係数 ( 門脈断面積 / 門脈平均血流速度)を算出した。なお, 門脈圧は T I P S 施行前後に血管造影用カテーテルで 測定した。

【結果】 T I P S 施行後。全症例で静脈瘤の消失を 得た。症例 2 , 症例 3 では腹水の著明な減少が得られ た。血清アンモニア值は一過性に上昇したが, 脳症の 発生はみられなかった。また。手技に起因する合併症 はなかった。1 回拍出係数は, 施行前の平均 $2.84 \ell$ I min/Kg-body weight に対して術後第 2 病日には平均 $4.99 \mathrm{l} / \mathrm{min} / \mathrm{Kg}$ - body weight, 術後第 5 病日には平均 $4.26 \mathrm{l} / \mathrm{min} / \mathrm{Kg}$ - body weight と增加した。これに伴い, 右房圧, 肺動脈圧, 肺動脈楔入圧も一過性に上昇した。 門脈流量は施行前の平均 $67 \mathrm{~m} \ell / \mathrm{min}$ に対して術後第 3 病日には平均 $801 \mathrm{~m} \ell / \mathrm{min}$ と上昇傾向を認めた。門脈圧 は平均 $36.7 \mathrm{mmHg}$ から平均 $26.3 \mathrm{mmHg}$ に低下した。

【まとめ】 T I P Sによって 3 症例とも門脈圧は低 下し。食道静脈瘤の消失および腹水の減少が得られた。 本法は臨床上極めて有用な治療法と考えられたが，血 行動態への影響として 1 回拍出係数の著增がられた。 その施行にあたっては, 合併症として心不全の発生に 十分留意する必要があると思われる。
示-32術後の肝性脳症発現率からみた選 択的シャント手術の合理性

埼玉医科大学第一外科

吉松栄彦, 小山 勇, 呴崎敏郎, 安西春幸, 鉫柄

稳, 尾本良三

【目的】食道静脈瘤に対する選択的シャント術 の限界, 殊に術後の肝性脳症について触れた報告は 少ない. 今回, 術後肝性脳症発生について分析した ので報告する.

【対象と方法】教室において施行されたシャント 術症例中術後 3 年間の追跡が可能であった17例を対 象とした. 平均年龄は 51歳(42〜62歳). シャント 術式は遠位脾静脈吻合(DSRS)10例, 左胃静脈下大 静脈吻合(LGCS) 7例であった. DSRSに関しては 原法に近い方法で行った. 術前のChild 分類では全 例がA又はBであった. LGCSの 1 例が予防的手術 であった他は全例が出血の既往のある待期例であっ た. 術前に肝性脳症の既往を有していたのは, DSRSの 1例のみであった. ただしこの 1例もかな り以前に軽度の脳症をみたにすぎなかった.これら の症例を術後 3年に至るまで追跡し, 肝性脳症（肝 不全）の発現頻度, 食道静脈窗出血の有無, 予後 （生死）等についてretrospectiveに分析した.

【結果】手術死亡はなかったが，食道静脈瘤の再 出血は 1例に認めた. 食道静脈瘤の消失は 1 例みら れた. 術後 3年までの死亡例は, DSRS, LGCSと も1例ずつあったがともに肝不全であった．肝性脳 症の発現率はDSRS群では, 術後 1年までに 10例中 4例 (40\%), 術後 3年 5/10 (50\%). LGCS群では, 術 後 1 年までに 7 例中 1 例 $(14 \%)$, 術後 3年で $2 / 7$ (29\%)であった. すなわちシャント術後例全体では, 術後 3年までに17例中 7例 (42\%)が肝性脳症（肝不 全）に陥った.このため朋性脳症となった症例では 日常生活にかなりの制約を受けるようになった.

【考察ならびに結語】選択的シャント術は, 門脈 圧を低下させずに食道静脈㢞のみを選択的に消失さ せるといら利点ゆえに受け入れられてきた. 我々の 症例で見る限り, 出血の既往があるにも関わらず再 出血は1例のみで, 出血予防の点からは非常に優れ ているという結果を得た. しかし, 術後3年以内の 肝不全もしくは重い肝性脳症の発現率は, DSRSで 50\%, LGCSで29\%と高く, これらの欠点に対しさ らなる改良が必要であることが示唆された. 
示-33肝硬変症における肝内外血行動態と食道 静脈瘤発生との関係について

山口大学第 2 外科

柳生岳志、西原説二、坂田光一朗、中島一毅、

久保秀文、鈴木 敬

【目的】肝疾畐時の食道静脈瘤形成機転には前方説、 後方障宫説、局所循環穴進説などがあり不明な点も 少なくない。今回、肝硬变症における肝内外血行動 態異常を明らかにするとともに、食道静脈瘤の発生 との関係について検討した。【対象】当科に入院し た肝硬变症33例中食道静脈癌合併17例（EV群）、非 合併 16例（NEV群)、およびcontrol群として組織学 的に正常肝と診断した46例（NL群）を対象とした。 Child-Pugh 分類 (A/B/C) はNEV群が 12 例 $/ 4$ 例 $/ 0$ 例、EV群が14例/3例/0例、ICGR15值 (\%;mean士 SE) はそれぞれ23士11.4,27士12.9であり両群とも 比較的良好な肝機能を示し両群间に有意差は認めな かった。【方法】超音波パルスドップラー法を用い、 門脈血流測定は門脈本幹、門脈右前枝、門脈左枝膰 部で行いそれぞれの血流量 $(\mathrm{ml} / \mathrm{min} / \mathrm{kg})$ を求めた。 肝静脈血流は右肝静脈 (RHV)、左肝静脈 (LHV) がIVCと合流する2〜3cm肝実缶側でそれぞれ測定し、 内径、平均流速(vmean)、Pulsatility index (PI) = (Vmax-Vmin) /Vmean を求めた。【結果】1) 右前

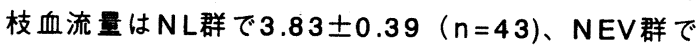
$2.09 \pm 0.38(n=14)$ 、EV群で2.45 $0.51 \quad(n=16)$ を 示し、NEV群、EV群はともにNL群に比し有意に低下 していたが（p<0.05）、EV群とNEV群との間には有 意差は認めなかった。門脈左枝楌部、門脈本幹の血 流量は各群間に有意差を認めなかった。2）RHVのPI

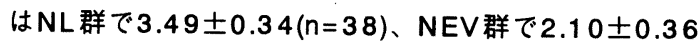

$(n=11) 、 E V$ 群で1.85 $00.36 \quad(n=12)$ を示し、

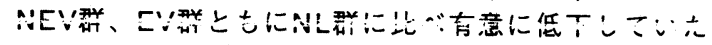
が（p৫0.05）、NEV群とEV群の間には有意差を認め なかった。一方LHVのPIはNL群で4.04 $(n=39) 、 N E V$ 群で3.08 $00.60(n=8) 、 E V$ 群で 1.18 $\pm 0.14(n=9)$ であり、NEV群とNL群の間には有意差 は認めなかったが、EV群はNL群およびNEV群に比べ 有意に低下していた（pð0.005、pめ0.05)。【結語】1） NEV群とEV群との㗑には肝内外の門脈血流量および 右肝静脈血流に有意の差は認めなかった。2）EV群 では左肝静脈のPIがNEV群に比べ有意に低下してい た。3）肝硬変における食道静脈瘤の発生には肝両葉 におよぶ実質の硬化が大きく関与しているものと考 えられ、その発生を早期に捕えるには左肝静脈の Pulsatility indexの低下が有用な指標と思われた。
示-34門脈合併切除再建に起因して合併症を 生した3症例の検討

岡山大学第一外科, 同医療技術短期大学部* 折田泰三, 津下 宏, 森 雅信, 舟木直人, 折田櫓三, 三村 久*

肝胆膵癌に対する根治切除術において, 門脈合併切 除再建は一般化し, 此較的安全な手術手技として確立 している。しかし, 頻度は少ないが, 合併症が発生す ることが報告され，われわれも3症例において門脈合 併切除再建に起因したと思われる重大な合併症を䅅験 したので報告する。

[対象と方法]最近10年間に, 門脈合併切除再建を行 った症例は勝癌 29 例, 胆管癌 16 例, 胆毫癌 4 例, 慢性 勝炎 2 例, 胆管細胞癌 1 例, 原発性硬化性胆管炎 1 例の 計53例であり，門脈合併切除再建に起因した合併症は 再建門脈閉塞, 間置移植静脈片壊死, 残胃静脈瘤破裂 のそれぞれ1例ずつであった。

[再建門脈閉塞例] 中部胆管癌に対して払大滕頭十二 指腸切除, 肝十二指腸間膜切除, 肝動脈再建, 右総腸 骨静脈片を用いての門脈間置移植再建を行った。術直 後よりLDH值が異常高値となり,T.Bil.值も徐々に 上昇して術後12日目に肝不全と腹腔内出血にて死亡 した。自家静脈片採取から門脈再建までの時間が長 かったことが閉塞の原因と考えられた。

[間置静脈片壊死例] 肝門部胆管癌に対して拡大肝左 葉切除, 肝十二指腸間膜切除, 右肝動脈再建, 右総腸 骨静脈片を用いての門脈間置移植再建を行った。術後 に胆管空腸吻合部繾合不全による腹腔内膿汮を生じ, 術後72日目に大量の吐下血が発生した。開腹すると, 移植静脈片が壊死に陥り, 門脈血が空腸脚内人流出し ていた。疮着瘄痕化した門脈周囲組織を縫合して救命 し得た。腹腔内感染による移植静脈片の壊死が生じた と考えられた。

[残胃静脈瘤破裂例] 膵頭部癌に対して扗大膵頭十二 指腸切除, 門脈端々吻合による再建, 脾静脈結愁を 行った。術後7カ月目頃より下血を生じ, 残胃静脈瘤 からの出血と診断された。残胃部分切除と残胃周囲の 血行郭清を行った。脾静脈結禁に伴ら脾静脈圧の上昇 が原因と考えられた。

[成績] 門脈合併切除再建53例において門脈合併切 除再建に起因する合併症が3例 (5.6\%)に生じた。間 置移植再建 14 例においては2例(14.3\%)に自家静脈片 移植に伴了合併症が発生し, 脾静脈結禁 21 例において は1例 $(4.8 \%)$ に胃静脈瘤の発生が認められた。

[結語] 門脈再建に自家静脈片を用いる場合には，そ の採取は再建直前に行らようにし, 胆管空腸吻合部縫 合不全を生じさせないよらに注意する必要がある。脾 静脈結禁例においては脾静脈圧測定を行い, 高値例に は門脈との吻合を試みる必要性があると思われる。 
示-35 特発性血小板滅少性紫斑病 I T P に対す る脾溚摘出術に関する検討 一開腹下脾脿摘出術と腹 腔鏡下脾应摘出術の比較検討一

北海道大学第 2 外科, 北海道消化器科病院 ${ }^{1}$ 佐藤兆昭, 西部俊哉, 高橋利幸, 道家 充, 奥芝俊一，下沢英二，加藤紘之，森田高行 ${ }^{1}$, [目的］特発性血小板減少性紫斑病（以下 I T P)の 治瘱法として副腎皮質ステロイド剂投与などの内科的 治療がまず行われるがその寛解率は低く、脾䐬摘出術 (以下脾摘)が最も信頼のおける治療法とされている。 しかし、従来の開腹術下では手術侵襲、術後愁訴も少 なくなく、そこで当科では1993年以降、侵襲も少なく 美容上の利点もえられる腹腔鏡脾摘術をもっぱら行う こととした。今回、開腹下脾摘及び腹腔鏡下脾摘につ いてその治痖結果を比較検討したので報告する。

[対象及び方法] 当科において1981年から1994年ま での14年間に脾摘を行った18例を対象とした。18例中 1992年までの13例は開腹下脾摘(以下開腹群)を行い、 1993年以降の 5 症例については腹腔鏡下脾摘(以下腹 腔鏡群)を行った。両者につき手術時間、出血量、手 術から退院までの期間及び治㽷成績について比較検討 した。

[結果］開腹下、腹腔鏡下併せた18例についてみる と完全寞解 10 例、不完全寞解 1 例、軽快 5 例、不変 2 例で悪化症例は無く脾摘の有効率は $56 \%$ であった。開 腹群13例についてみると完全寛解 6 例、不完全宽解 1 例、軽快 5 例、不変 1 例で脾摘有効率は $46 \%$ 、一方腹 腔鏡群では完全寞解 4 例、不変 1 例で有効率 $80 \%$ であ つた。手術時間は開腹群が平均140分、腹腔鏡群が平 均313分と腹腔鏡群で有意に長かった。出血量は開腹 群が平均 $254 \mathrm{cc} 、$ 腹腔鏡群は平均 $72.5 \mathrm{cc}$ と腹腔鏡群で 有意に少なかった。手術から退院までの期間は開腹群 が平均 12.4 日、腹腔鏡群が平均 9.4 日で短い傾向にあ った。

[結語] 腹腔鏡下脾摘術は我が国にも1992年より導 入され当科でも1993年より施行してきた。しかし、そ の治洂効果などについては報告が少なく、開腹下脾摘 と比較検討し評価した報告はない。検討の結果、脾摘 効果については差がなく、開腹下脾摘に比べ出血量は 有意に少なく、また入院期間も短かった。手術時間は 開腹下脾摘に比較して長いが最近の症例では著明に短 縮されており、術式に熟練することによりさらに短縮 が可能と思われる。腹腔鏡下脾摘は開腹下脾摘に比べ 手術侵䪭、疼痛などの術後愁訴も軽度であり、I T P が若年女性に多いことから美容上の利点も十分に生か されると思われる。以上から、I T Pに対する脾摘は 腹腔鏡下脾摘術が安全に施行できるようになった今日、 いたずらに薬物治療に固執することなく比較的早期に 実施に踏み切るべきであると思われる。
示-36 真性多血症に合併した脾結核の1例

牛久爱和総合病院 救急科

竹内宗和 曾我幸弘 久保田英 花房茂樹

村瀬 茂 倉光秀磨

【症例】80歳、女性。左胸痛を主訴に来院。既往歴； S58年、心筋梗塞疑いで入院するも諸検査で異常なし。 現病歴; 平成 5 年 9 月初旬頃より時々、左季肋部の鈍 痛出現し近医受訩。狭心症の診断で内服治療にて軽快。 11月17日同様の発作が出現、症状軽快せず当院紹介と なる。

【入院時現症】意識：清明、血圧：180/100mmHg 脈拍: $134 /$ 分 呼吸: $30 /$ 分 体温: $35.2^{\circ} \mathrm{C}$ 眼瞼結 膜に筫血、黄疸なし。顔面苦閶様で左胸痛を訴えてい たが䅡部、胸部に所見はなく左㑡腹部に軽度圧痛を認 めた。

【検查所見】WBC $18600 / \mathrm{mm}^{3}$ RBC $588 \times$ $104 / \mathrm{mm}^{3} \quad$ GOT $18 \mathrm{IU} / \mathrm{L} \quad \mathrm{CPK} 36 \mathrm{IU} / \mathrm{L} \quad$ CPK-MB $5.8 \mathrm{MU} / \mathrm{ML}$ 胸部X-Pで左側胸水を認めた。腹部エコー では脾上方に後方陰影の増強および側方陰影を伴わな い、辺縁整の hypoechoic leisionを認めた。腹部CTでは 単純および造影CTで脾腫と、多発性のlow density area を認めた。MRIでは頭側の腫嘴は、T1強調画像で正常 脾より高信号強度、T2強調画像で不均一な低信号強度 を示した。尾側の腫㿔はT1強拥画像では描出できず、 T2強調画像で低信号強度を示した。選択的脾動脈造影 では動脈相、静脈相共に異常は認められなかった。

【経過】左側腹部の鈍痛が消失せず、悪性疾患も否定 できなかったため 2 月 8 日手術となった。脾脭はラグビ 一ボール大に腫大し $(1400 \mathrm{~g})$ 、胃、結腸、横隔膜と炎 症性に瘾着しており、特に脾門部療着は強固だったため 羘尾部合併切除となった。摘出標本の病理組織検査では、 病巣部は全て乾酪巣を伴ったLanghans 巨細胞を有する glanulomaが散在していた。術後、反応性に白血球は最高 $43,000 / \mathrm{mm}^{3}$ 血小板は 375 万 $/ \mathrm{mm}^{3}$ まで上昇したが化学療 法により徐々に改善した。

【考察】脾のMRIに関する報告はいまだ少ない。また 脾結核におけるMRIの所見を示す報告も散見しない。今 回われわれの経験した症例によると脾結核でのMRIの所 見はT1強調 T2强調画像で一定していないためMRIでの 銚別は困奞と思われた。本症例は脾胼以外には結核病変 を認めず原発性脾結核と考えられた。また経過中1.脾腫

2.WBC $>12,000 / \mathrm{mm}^{3} \quad 3 . \mathrm{Plt}>40$ 万 $/ \mathrm{mm}^{3}$ と真性多血症 の診断基準を満たした。一般に真性多血症の脾腫に対す る脾摘は禁忌とされているが、今回、術後化学療法で出 血傾向、血栓症等の合併症は認められなかった。

【結語】1.真性多血症に合併した脾結核という稀な症 例を経験したので報告した。2.脾結核に対するMRIは一 定の所見を呈さず、診断には有用でなかった。 
示-37膵尾部癌の横行結腸浸潤により腸管穿孔 をきたし，孤立性脾膿瘍を形成した 1 例

済生会日田病院 ${ }^{1)}$, 久留米大学第 1 外科 ${ }^{2)}$

酒井浩一 ${ }^{1)}$, 西村 寛 ${ }^{1)}$, 小中敏生 ${ }^{1)}$, 犬塚清久 ${ }^{1)}$, 散川暉夫 ${ }^{2)}$

孤立性脾膿煬は稀な疾患で, 本邦では現在までに本 症例を含め 33 例が報告されているだけである。さらに 膵癌に合併したものは, 本症例を含め 3 例と極めて稀 であるため, 若干の文献的考察を加え報告する。

症例は 53 歳男性で, $40{ }^{\circ} \mathrm{C}$ の発熱を認め近医入入院 した。入院後も発熱が続き, 6 日目に腹痛, 腹膜刺激 症状を認めたため当院救急外来へ搬入された。入院時 現症では腹部全体に著明な圧痛を認め, 腹壁は板状硬 を呈していた。腹部超音波検査, CT検査で脾臓内にガ ス像を伴う腄留を認めた。注腸造影で脾彎曲部に狭窄像 を認めたため, 横行結腸癌の穿孔による汎発性腹膜炎 と脾膿瘍と診断し開腹手術を行った。術中所見では, 腹腔内に黄色の膿を認め, 脾彎曲部で膵尾部と横行結 腸と脾臓は一塊となっており, 横行結腸穿孔部が脾藏 へ穿破し脾膿場を形成していた。乙の膿煌より大腸菌 を検出した。また, 肝右葉に腫瘤を触知した。横行結 腸と膵尾部と脾臟を切除し, 人工肛門を作成した。病 理組織検查で膵藏の adenosquamous carcinoma の横行 結腸浸潤と診断された。術後 1 力月で多数の肝転移を, 3 力月で膵体部に青, 左腎臓, 腹壁, 周囲の腸管へ浸 潤する腫瘤の再発を認め, これらの増大と共に全身状 態が悪化し, 入院後約半年で死亡した。

孤立性脾膿演は, 他臟器に膿暘がなく脾内に 1 力所 のみ膿瘍を有するもので, 膵癌との合併は本邦では 3 例と極めて少ない。過去 2 例の報告例は， 65 歳の女 性で発熱と腹痛を主訴とし, CT, 超音波検査で脾膿癔 と膵尾部の衰胞を認め, 脾摘と膵尾部切除を行い, 病 理組織検查で papillotubular adenocarcinoma と䛦断 され予後良好であった症例と 54 歳の男性で発熱と左季 肋部痛を主訴とし, CT, 超音波検査, ERCP を行い脾 膿煬と睟尾部癌を疑い, 抗生物質による内科的治療に より脾膿場の消失を待って, 膵尾部切除, 脾摘, 横行 結腸の部分切除を行い, 病理組織検査で duct cell carcinoma と診断され術後約半年で死亡した症例であ る。症例 1 では, 脾膿煌と膵癌との関係は不明であり, 症例 2 では，膵癌の脾門部への浸潤により脾梗塞をき たし， 2 次的感染により脾膿煬を形成したものであり， 本症例とは成因が異なっていた。本疾患の原因として は, 他の感染巣よりの血行性の波及, 腹部外傷, 脾周 囲感染巣よりの直接侵襲, へモグロビン異常などがあ るが悪性腫煌との合併も念頭におき, 個々の症例に適 した治療を行うことが大切であるものと思われた。
示-38

1 例

空腸癌の再発肝転移切除後の長期生存の

岡山赤十字病院外科

池田英二, 大塚康吉, 川上俊爾, 古谷四郎,

辻 尚志, 山田真人, 内藤 稔, 小野監作,

寺本 淳, 大西洋一

近年, 肝蔵外科が進歩し, 転移性肝腫漡に対して積極 的に肝切除が行われ，その遠隔成績は意外に良好であ る。われわれは比較的稀な空腸癌を切除し，1年4力月 後に肝転移を発見しこれを切除した。その後7年4力 月再発なく健在である症例を経験したので報告する。

症例：70才の男性で, 主訴は哣気, 嘔吐である。昭 和60年1月中旬より嘔気, 嘔吐を訴え, しだいに食欲 不振となり，3月 25 日当院に入院した。腹部は平坦で, 腫瘤触知なく, CEAは $12.8 \mathrm{ng} / \mathrm{m} 1$ と高値を示し, 小 腸造影でT reitz勒帯直下の空腸に全周性の狭窄, 動脈 造影で空腸に腫煌染を認め, 空腸癌の診断で4月 17 日 開腹した。腹水, 肝転移なく, Treitz勒帯より $3 \mathrm{~cm}$ の 空腸に輪状狭窄を伴った小鵎卵大の腫瘤と小腸間膜り ンパ節の腫大を認めた。狭窄部より口側, 肛門側それ ぞれ $5 \mathrm{~cm}$ の小腸を切除し, 端々吻合した。組織診断は 中分化型腺癌で, 壁深達度はseで, 小腸間莫リンパ節 7 個に転移を認めた。術後CEA2.5ng/m1 正常値に なり, 術後化学療法としてFT $207600 \mathrm{mg} /$ 日, PSK 3.0/日を投与し，5月16日退院した。通院中術 後 9 力月目にCEA $29.5 \mathrm{ng} / \mathrm{m} 1$ と上昇し, 腹部CTでは 肝転移及び再発は認めなかった。さらにCEAは上昇 し, 術後1年2力月目CEA84.5ng/ $\mathrm{ml}$ となり, 腹部工 コーで肝左葉に $3 \mathrm{~cm}$ 大の腫瘍エコーを認め, 昭和 61 年 8月9日再入院した。特に自覚症状はなく, 腹部は平坦 で, 圧痛, 肝触知も認めなかった。動脈造影で肝左葉 に腫瘍染を認め, 空腸癌の肝転移と診断し, 8月 22日 肝左葉を切除した。肝転移巣は外側後区域で，大きさ は $3.2 \times 3.0 \times 2.7 \mathrm{~cm}$ であった。他の腹腔内には再発を 認めなかった。組織診断は空腸癌の肝転移で, 墏膜浸 潤はs1であった。術後化学療法は行なわず, 9月13日 退院した。その後定期的に通院し, CEA, 腹部エコー 検査するも異常を認めず, 肝切除後7年4 4 月再発なく 健在である。

小腸癌は一般に診断が遅れがちで,そのために予後 不良といわれている。また再発転移した症例を切除 し, 再発なく長期生存した報告例はほとんど見られな いので,この症例を報告する。 
殿田胃腸肚門病院

南 光昭, 殿田重彦、湯川裕史，下間仲裕 和歌山県立医科大学・第二病理

\section{覚道健一}

小腸に発生する神経鞘腫はまれな疾患であり，特に 覀性神経鞘腫の本邦報告例は十二指腸を除く空・回腸 では自験例を含め9例しかない。今回われわれは空腸 に原発し穿孔をきたした悪性神経鞘腫を経験した。

【症 例】68歳・男性。

【主 訴】腹部激痛。

【現病歴】1993年 3 月 9 日夜間より腹痛あり。10日朝 に腹部激痛となったため当院救急受診となる。

入院時現症および経過：腹部全体に圧痛之筋性防禦を 認めるも腫瘤は触知しなかった。消化管穿孔を疑い穿 孔部位を確定するために上部消化管内視鏡検査および ガストログラフィンによる経口造影検査を行った。胃 十二指腸に異常はなく，経口造影検査でTreitz勒帯よ り約 $10 \mathrm{~cm}$ の部位に異常陰影を認めた。しかし確定診断 にはいたらずまた腹部所見む軽減したために保存的治 療にて経過を追った。その後も左上腹部に圧痛が持続 していたため入院 7 日目に再度ガストログラフィンに て経口小腸造影検査を行った。2度目の検査では造影 剤の腸管外への漏出を認め小腸穿孔と診断, 開腹手術 を行った。

【手術所見】 Treitz鞘帯より $10 \mathrm{~cm}$ の空腸腸間膜側に径 約 $5 \mathrm{~cm}$ の弾性硬の腫瘍があり, 中央部で穿孔していた 穿孔部は近傍の腸管および腸間膜にて被覆され，限局 性の膿瘍腔を形成していた。腫瘍を含め空脂部分切除 術を施行した。腫瘍は 1 ケ所のみで他の消化管には認 めずリンパ節転移、肝転移、腹膜播種は認めなかった。

【切除標本および病理診断】腫瘍は $4 \times 3 \times 3 \mathrm{~cm}$ 大で 主に管外発育していたが，管腔内にもBorrmann 2 型 様に突出しその中央部で深い潰瘍を形成し穿孔してい た。病理組織像はH.E.染色では平滑筋肉腫との鑑別は 困難であったが，免疫組織染色でS-100蛋白陽性， desmin 陰性であり，また腫瘍細胞は異型性があり空 腸原発覀性神経鞘腫と診断した。

手術後 1 年経過するむ再発なく生存している。 自験例を含めた本邦報告例 9 例について文献的考察を 加えて報告する。
一例

\section{警友総合病院外科}

原田裕久, 松本秀年, 加瀬 卓, 嶋田昌彦, 吉田博之, 渡辺 衛

成人 T 細胞白血病（以下A T L ）は末梢 T 細胞の腫 瘍性増殖により多彩な病態を呈する疾患である。今回 我々は、A T L 細胞の浸潤により 2 回の小腸穿孔を来 たした症例を経験したので報告する。

[症例］53歳女性。平成元年 1 月、A T L と診断され、 V E P A 等の化学療法施行後、同年12月にはC R の所 見が得られた。その後再燃の兆候は見られなかったが、 約 4 年後の平成 4 年 12 月になって突然の下腹部痛が出 現し来院した。消化管穿孔による汎発性腹膜炎と診断 し、緊急手術を施行!た。

[第 1 回手術所見］回腸末端付近に穿孔が羿められ、 またTreiz勒帯より $220 \mathrm{~cm}$ 部の小腸に粘膜下腫瘍様の病 変による高度の閉塞が見られた。この 2 力所にて小腸 部分切除術を施行した。閉塞部の口側には多数の粘膜 下腫瘍様病変が残存していた。病理組織学的には粘膜 下層を中心に全層性に A T L 細胞の浸潤を認め、A T Lの再燃による小腸浸潤のための穿孔と診断した。

[術後経過］経過良好であり、C H O P 療法を施行し たところ、約 1 力月後 C T及び G a シンチ上、残存腫 瘍影は消失した。その後愁訴なく外来通院していたが、 約 7 力月後の平成 5 年 7 月、再び激しい下腹部痛にて 来院、汎発性腹膜炎の診断にて再度緊急手術を施行し た。

[第 2 回手術所見］回腸末端付近にて膿苔の付着した 腸管が炎症性変化を伴って一塊となって癒着しており、 この部位での穿孔を疑い、切除した。病理組織学的に も A T L 細胞の浸潤による穿孔に合致した所見であっ た。

[術後経過］経過良好であり、再度化学療法を施行し た後退院したが、全身状態次第に悪化し、約 5 力月後 の12月に死亡した。

[ま亡め］ＡＴＬは治療に抵抗性で、急性発症してか らは急速に死に至る予後不良な疾患である。消化管へ の浸潤例はまれであり、小腸浸潤による穿孔例の報告 も見られるが、いずれも末期であって全身状態が極め て不良であり、手術により救命し得た例は検索し得た 範囲で本症例が初めてである。また、本症例は平成元 年当初、急性白血病型にて発症し、化学療法にて一度 C R となった後は死亡するまで一度も白血化を見ず、 腸管浸潤の形のみで再燃した。このような例も他に類 を見ず、貴重な症例と思われたため報告した。 
示-41腹腔内出血，穿孔性腹膜炎をきたした 肺癌小腸転移の2例

国立療䓹所西群馬病院外科 ")、群馬大学第2外科 2)

小林純哉 11 , 蒔田富士雄 ${ }^{11}$, 遠藤敬一" 1 、

大和田進 ${ }^{2)}$ 、森下䍪雄 ${ }^{2)}$

【はじめに】肺癌の小腸転移の報告は散見されるが， 腹腔内出血また穿孔性腹膜炎という比較的稀な症状で 発症した2症例を経験したので報告する。

【症例1】63藏の女性で, 咳濑と血痰を主訴に近医を受 診した。右血性胸水の貯留を認め, 細胞診はadenocarcinomaであった。癌性胸膜炎の診断で精查加療の目 的で当院に転院した。原発は右肺 $\left(S^{10}\right)$ と診断され たが，入院中に進行する隹血と腹満が出現し，保存的

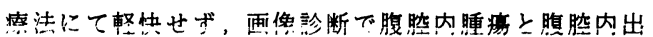
血の診断で開腹術を施行した。多量の血性腹水があり， 小腸, $\mathrm{S}$ 状結腸, 晹管膜に一塊となった腫凝を認め, その一部から腹腔内へ出血していた。腫湯は切除し小 腸吻合と人工肛門造設を行ったが, 病理診断は肺癌の 転移性腫湯であった。

【症例2】65藏の男性で, 血痰を主訴に近医を受診した。 右上肺野に腫瘤陰影を認め, 喀痰細胞診がadenocarcinomaであり, 当院に転院となった。右肺癌 $\left(S^{2}\right)$ の診断で開胸術を施行したが, 腫瘤は後胸壁に強固に 瘾着し, 肺動静脈にも直接浸溜を認め, 切除不能であ った。さらに右肺全体に胸腔播種と思われる多数の結 節と, 多数の縦隔リンパ節の腫大を認めた。術後放射 線照射と化学㙩法を行っていたが, 約 4 ヶ月後に上腹部 痡が出現し腹部X-pにてfree airを認めたため, 穿孔 性腹膜炎の診断で開腹術を行った。小腸に腫㿋を認め 同部位に穿孔を認めたため, 晹切除術を行ったが, 病 理診断は肺癌の転移であった。

【まとめ】肺癌の小腸転移は剖検例の約 $5 \%$ に認められ るが, 臨床上での報告は比較的少ない。症状は穿孔， 腸閉塞症状が多く, 他に下血等も認めるが, 腹腔内出 血により発症した症例の報告はない。術前に確定診断 がなされ手術に至った症例は少なく，本2症例も腹腔内 出血と穿孔という症状をきたした症例で, 救急救命処 置として手術が施行され, 肺癌の小腸転移と診断され た。

以上, 比較的稀な症状で発症した肺癌の小腸転移2症 例を経矝したので若干の文献的考察を加え報告する。
示 -42

非外傷性小腸穿孔症例の検討

一とくに予後を左右する因子について一

岐皁市民病院外科

大下裕夫, 田中千凱, 種村廣巳

【はじめに】外傷性を除外した小腸穿孔では，原因となる 病態や疾患が多岐にわたっており，術前診断が困難で重 篤となる症例が多く, 高い死亡率が報告されている。今 回, 我々は非外傷性小腸穿孔の臨床像を検討し, とくに, 予後を左右する因子について分析した。

【対象】1975年 1 月から1994年 1 月までの約19年間に 当科で手術された十二指腸を除いた非外傷性小腸穿孔 27 例を対象とした．性別は男性19例，女性 8 例で，年粭は 20〜83歳, 平均59.6歳であった.

【結果】穿孔の原因疾患(病態)はそけいヘルニア嵌頓 3 例, イレウス 3 例, 盲軎炎 3 例, 異物 2 例, メッケル㝆室 2 例, 放射線腸炎 2 例, 閉塞性腸炎 2 例, 悪性リンパ腫 2 例, 腹壁痗痕ヘルニア嵌頓 2 例, イレウスチューブ 2 例, 上腸間膜動脈閉塞症 1 例, 腸管壊死 1 例, 平滑筋肉腫 1 例, 吻合部潰瘍 1 例であった，穿孔部位は回腸17例, 空 腸 9 例, 不明 1 例で, 穿孔の個数は単発 23 例, 多発 4 例 であった. 術前症状では, 腹膜刺激症状が21例(77.8\%), ショック状態が11例(40.7\%)に認められた. 白血球数は $10,000 / \mathrm{mm}^{3}$ 以上 11 例 $(40.7 \%), 10,000 / \mathrm{mm}^{3}$ 以下 14 例(51.9 \%), 不明 2 例であった. 単純X線撮影で遊離ガス像を認 めた症例は18例(66.7\%)であった. 手術術式は小腸切除・ 吻合15例, Exteriolization6例, 小腸切除 - 回腸㿉 3 例, 楔状切除・縫合 2 例, その他 1 例であった. 術中腹水の 細菌培養検査が施行された11例の起炎菌はE.coli 5 例, Klebsiella pneumoniae 3 例などであった. 死亡例は12 例(44.4\%)で, 11例(40.7\%)が手術死亡であった.つぎに, 死亡例12例の臨床像について検討した. 性別は男性 6 例, 女性 6 例, 平均年齢は64.3歳であり, 生存例の55.9歳より も高龄であった. 発症から手術までの時間之死亡率との関 係をみると，12時間以内 $27.3 \%(3 / 11) ， 24$ 時間以内 62.5 $\%(5 / 8) ， 24$ 時間以上 $50 \%(4 / 8)$ であった. 主な入院時所 見や検查所見亡死亡率との関係をみると，腹膜刺激症状 では陽性例47.6\%(10/21)，陰性例33.3\%(2/6)，白血球 数では $10,000 / \mathrm{mm}^{3}$ 以上 $27.3 \%(3 / 11), 10,000 / \mathrm{mm}^{3}$ 以下 57.1 \%(8/14)など, 腹腔内の遊離ガス像では陽性例50\%(9/

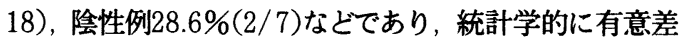
はみられなかった. しかし, 術前ショック陽性例の死亡率 は72.7\%(8/11)であり，陰性例25\%(4/16) と比べて有意 に高率であった $(p<0.025)$. 穿孔部位と死亡率との関係 は回腸52.9\%(9/17)，空腸33.3\%(3/9)などで，差異は みられなかつた. 手術術式別に死亡率をみると, Exteriolization $83.3 \%(5 / 6)$, 小腸切除· 回腸瘦 $66.7 \%(2 / 3)$, 楔状切除・䋖合50\%(1/2)，小腸切除・吻合 $26.7 \%(4 /$ 15)などであった. 腹膜炎と死亡率についてみると，起炎

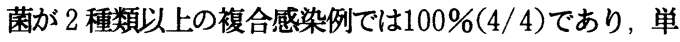

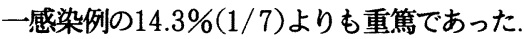

【まとめ】1)非外傷性小腸穿孔の原因疾患はさまざまで あるが, 死亡率は $44.4 \%$, 手術死亡率は $40.7 \%$ 之高率であっ た. 2) 予後を左右する因子として, 高龄, 術前のショック 状態， 2 種類以上の起炎菌による腹膜炎が重要である. 
$398(1570)$

示-43先天的にATIIJおびProteinC欠在を有し、 上腸間膜静脈血检症を発症した一例

みなと医療牛協協立総合病院外科

愛知県コロニ一中央病院小児外科

浅野道雄、原晴久、安藤久實太

【はじめに】上腸間膜静脈血栓症の患者に対し腸切除お よび強力な抗凝固療法を行い救命し、術後の検索で興味 ある線溶系の先天的異常を認めた症例を経験したので報 告する。

【症例】20歳男性。学竟期より上下肢静脈血栓疛の既往 を有し、18歳時他院にて下肢深部静脈血栓症の診断にて Panaldineを投与されていた。家族歴に特記すべきことな かった。1993年10月9日、吖向、腹痡を主訴に当院を受診 した。

【血液生化学的所見】血液検査では白血球の軽度上昇の 他異常を認めず、生化学的検查でも GOT、GPT、LDH、CPK、 Bi1などに異常を認めなかった。ATIII活性は40\%であっ た。

【各種検查所見】腹部 C Tで壁肥厚を伴う腸管の拡張像 を認めた。腹部超音波㭘査では、晹管壁肥厚と腹胿内液 体貯溜を認めたが、門脈像は描出できなかった。腹腔穿 刺により血性腹水を認めた。上腸間膜静脈血栓症を強く 疑い、手術を施行した。

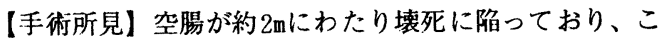
れを切除し端々吻合した。また、術中門脈造影を施行し たところ、門脈完全閉塞を認め、Fogatyカテーテルを用 い可及的に血栓を除去した。門脈内にIVH用カテーテルを 留置し体外に出し、閉腹した。

【経過】術後、門脈カテーテルからのUrokinase注入、 ATIII製剂・heparin全身投与を行った。また、術後2日目 に試験開腹を行い、腸管の再壊死のないことを確認した。 順調に回復し、warfarinを投与して退院となった。

【凝固線溶系検索】術後検索により、父親にATIII矢乏、 母親にProteinC欠乏のあることが判り、患者にATIIIおよ びProteinC両者の久乏症を認めた。

【考察】上腸間膜静脈血栓症は、その発症に先行して門 脈閉塞を伴うことが少なくないとされ、本症例でも、術 前後ともに肝機能異常を全く認めなかったことから、も ともと門脈閉塞・側副血行が存在していたものと考えら れた。一方、若年男子の下肢深部静脈血栓症に、上晹閒 膜静脈血栓症を合併する場合、一群の疾患概念として考 えるべきであるという指摘がある。原因を特定できず特 発性とされる例が多いが、本例は、術後の検索により2つ の線溶系酵素の異常を認め、先天的にリスクの高い状態 にあったものと考えられ、発生機序からみても興味深い 一例であった。
日消外会誌 27 巻 6 号

示-44 小腸保存後の小腸粘膜防御機能と吸収機 能の変化に関する実験的検討

1 香川医科大学第一外科、 2 ピッツバーグ大学移 植外科

國土泰孝1,2、竹吉泉 ${ }^{2} 、$ 藤堂省 ${ }^{2} 、$ 前場隆志 $、$ 、田中聘1 [目的］保存小腸の粘膜の防御機能の低下は小得移 植後のエンドトキセミアの発生に関連し非常に重要 である。今回我々は、Ussing chamberを用い、保存 後の小腸粘膜の防御權能の変化と吸収、分泌機能の 变化を空䏸と回渴で検討し、それらの冷保存に対す る障客度の差についても検討したので報告する。

[方法] Lewisラットを使用し、冷釈酸加Ringer液 で小腸を筄流し、0,6,12,18時间(各 $n=6)$ 冷乳酸加 Ringer液 $\left(4^{\circ} \mathrm{C}\right)$ 中に保存した。保存後空腸と回渴

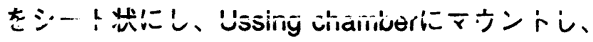
95\%O2+5\% $\mathrm{CO}_{2}$ で酸菜化したKrebs-Henseleit液で

灌流し再酸秦化した。Ussing chamber上で小晹の防 御機能のパラメーターとして小晹のelectric resistance(R) とFITC-dextran (MW4400)の permeabilityの測定を行った。villus absorptive cell の吸収機能の評価にはglucoseによる刺激試験を行 い、crypt cellの分泌機能の評価にはTheophyllineに よる刺激試験を行い、刺湤によるpotential difference(PD)の変化を覧察した。保存終了時と再 酸菜化1時间後小腈組織を取り組織学的变化を覧案 した。

[結果] Rは空晹と回晹で保存時间の延長に伴い低 下したが、12,18時间保存後空晹では回晹より有意 に(p<0.01)高かった。FITC-dextranにより測定した permeabilityは、空渴では上昇が認められなかった が、回腸では12,18時间保存後有意の $(p<0.05)$ 上昇が 認められ、空肚と比較しても有意に $(p<0.05)$ に上昇 していた. glucoseによる刺激試駼で心、空盟上回 周ともに保存時间の延長によりPDの反応は低下した。 保存後のTheophyllineによる刺激試験では、空腸の PDの反応が回腸より良く保たれていた。組織学的に は、保存時间の延長にともない組織学的浮䤚がvillus tipより cryptに向かい進行していた。

[結論] 保存後RとFITC-Dextranのpermeabilityより 評価した小晹粘膜の防御機能は、空渴よりも回腸で 低下が大きかった。villus absorptive cellの椎能は、 空腸と回晹ともに強く障害された。空渴のcrypt cell の分泌檴能は回晹より良く保存された。以上の結果 より冷保存に対する障害度は回晹のほうが高いと思 われる。 
示 -45

用か?

UW 保存液中のグルタミンは小腸保存に有

札幌医科大学第一外科, ペンシルバニア大学外科* 佐々木一晃, 小出真二, 八木橋厚仁, 高坂 一, 鳥本勝司, John L. Rombeau*, 平田公一

臟器移植において, 最適な臟器保存の確立がその成 功に必須であるが, その臟器保存に最適な保存液でさ え異論のあるとてろである。一般に小腸の保存に UW 液を使用するがグルタミン $(\mathrm{Gln})$ を加えることはない。 しかし, Gln は小腸粘膜の栄養源となるとともに, そ の構造, 機能を保持する作用を持つ。そてでより最適 な保存液の確立のため, Gln の保存小腸に対する作用 を検討した。

【対象と方法】Lewisラットの空腸 $(40 \mathrm{~cm})$ を用いた。 空腸摘出時, 冷生食 $10 \mathrm{ml}$ で摘出空腸内を洗浄した後, SMAからへパリン100Uを加えた各群の冷保存液 $5 \mathrm{ml}$ 腸壁内血液を除去した。UW液中に $1,2,4 \%$ G $\mathrm{ln}$ を 加え, 4 C, 18時間の臟器保存を行った (G1, G2, G4 群)。保存腸管内む各保存液 $20 \mathrm{ml}$ で緩徐に還流し保存液 で満たした。対照群として $4{ }^{\circ} \mathrm{C}, 18$ 時間のUW液単独群 (A群), Gln 亿代え1，2，4\%の NEAAの群 (N1, N2, N4群)，および保存時間0時間の対照群（B群）とした。 保存小腸の機能, 状態の評価として, 1) 保存腸管の糖 透過試験，2）粘膜の重量, タンパク量の測定, 3) brush border 内酵素の Alkaline phosphatase やMaltase 等の 測定, 4) 組織学的所見を測定した。

【結果】糖透過試験：A群で $0.47 \pm 0.03 \mu \mathrm{mol} / \mathrm{cm}^{2} / \mathrm{hr}$ であったものが, G1, G2, G3群で 0.53土0.17, $0.84 \pm$ $0.09,1.01 \pm 0.05$ と増加し, G2, G3 群ではA, G1群に 比へ有意に空腸の糖透過量が増加した。しかし, B群 の $1.65 \pm 0.29$ までは改善しなかった。また, G2 群は N2 群に比へ，G3群はN33群に比べ有意に高值を示した。

しかし，G2とG3群の間に有意な差はなかった。粘膜 重量：B群で $60.4 \pm 3.3 \mathrm{mg} / \mathrm{cm}^{2}$ が A 群で $84.8 \pm 2.5$ と有意 に増加した。G1群はA群と差を認めなかったが，G2， G3 はA 群, G1群に比へ有意に低值で, B群之同程度 の粘膜重量に保たれた。粘膜タンパク量 : A 群の 1.65 $\pm 0.05 \mathrm{mg} / \mathrm{cm}^{2}$ がG2, G3群で $2.01 \pm 0.07,2.18 \pm 0.07$ と 有意に増すとともに，N2群に比し有意に高値であった。 粘膜内酵素: maltase は $\mu \mathrm{mol} / \mathrm{min} / \mathrm{g}$ protein で表示 される。各群ともほぼ同様の值を示した。つまり，G2， G3群で酵素量が多かった。組織学的検索: 䋐毛の高さ はA群の $225.8 \pm 9.6 \mu \mathrm{m}$ が $\mathrm{G} 2, \mathrm{G} 3$ 群で $246.5 \pm 8.9$, $252.1 \pm 4.4$ 之增した。組織の浮腫, 粘膜細胞障害むG2, G3群で軽度であった。

【まとめ】UW液での小腸低温保存に際し Gln は有用 な添加剤であり，その濃度は $2 \%$ が適当である可能性 が示された。
示 -46 大量下血における出血部位同定のための
各種緊急検查法の意義

埼玉医科大学第 1 外科

錦織吉宏、小山 勇、松本 隆、安西春幸、荻原正規入、 沼尻良克、山崎達雄、尾本良三

ショックを伴う大量下血の患者では、輸血の治療を始 めるとともに、出血源を探すための内視鏡検査が行わ れることが多い。しかし、しばしば、出血源が判明せ ず、診断および治療に難渋する症例を経験する。その ような症例では、シンチグラフィーや血管造影検查な どが有効とされるが、かならずしも満足な結果が得ら れているわけではない。今回、内視鏡にて出血源を明 らかにできなかった症例における、出血源検索のため の種々検查の意義を明らかにすることを目的に検討し た。

[対象および方法] 1989年 1 月から 1994年 1 月の 5 年 間に、ショクを伴う大量下血を主訴に来院し、上部消 化管出血を除く9 例（男性 4、女性 5 ）を対象とした。 大腸ファイバー検査と出血性シンチグラフィー

(99mTc-DHSA)を全例に行なった。さらに手術前に出 血源を確認す必要があった 3 例に血管造影検査をおこ なった。

[結果] 9 例中 5 例に手術を行い、クローン病 1 例、大腸 款室炎 1 例、メッケル香室炎 1 例、結節性動脈周囲炎

（PN）1 例、不明 1 例であった。他の 4 例は、保存的 に軽快し、大腸㮩室 2 例、不明 2 例、うち 1 例は肝硬 変による肝不全を伴う症例で出血源不明のまま死亡し た。大腸ファイバーにて、大腸㮩室 3 例が確認できた が、出血点が判明した症例はなかった。シンチグラフ イーでは、9例全例に腸管内への漏出を確認したが、 出血源のおよその同定ができたのはわずか 3 例（3/9） であった。この 3 例では全例手術を施行した。また、 血管造影はPN、メッケル㮩室、大腸㰾室の 3 例に行い、 うち 2 例において出血点が確認できた $(2 / 3)$ 。大腸䕀室 の症例では確認できず、シンチで陽性であった。3例 いずれも手術を施行した。

[結論]緊急検査を要する大量下血では、大腸ファイバー 検査は有効ではなかった。出血シンチグラフィーは陽 性にでる率は高いが、部位の同定率は $30 \%$ 程度であ り、検査法の改善が望まれた。血管造影検査は、診断 率は高いが、出血の最中に行う必要があり、検査の夕 イミングが問題となりうると思われた。 


\section{示-47当院における消化器外科術後感染症につい ての湌討}

奈良県立三室病院 外科 小山文一，前田夏人，西和田敬，八木正别

当院において1989年から1993年までの 5 年間に施行 された手術件数は1937例で，このうち全身麻酔下での 消化器外科手術症例は812例であった.

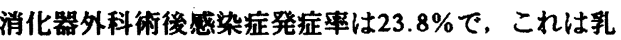
房, ヘルニア等の体表手術の術後感染症発症率 $(1.3 \%$ ）と比較して蕃しく高かった．また術後感染性合併症 の死亡事は11.3\%にも達していた。

主な㭪後感染症の全感染症例に占める割合は, 腹腈 内感染 (汎発性) $12.1 \%$ ，腹㓐内感染 (限局性) 24.4 $\%$ ，肺炎 $19.5 \%$ ，渴炎 $31.7 \%$ ，㓣感染 $34.1 \%$ であった。 特に腹坓内忽染 (汎発性) は死亡事 $80.0 \%$ と高く非常 に危険な合併症であったが，イレウスでの緊急手術例 が約半数を占めた．次いで死亡事が高かったのは肺炎 の $25.0 \%$ で, 食道手術, 胃全摘術, また高齡者に多く 発症した.

手術別術後感染症発症率では，食道手術 $75.0 \%$ ，胃 全摘術 $34.6 \%$, 胃切除術 $17.4 \%$, 結腸手術 $20.0 \%$, 直

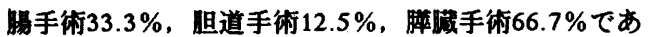
った，食道手術では，肺炎およひ站合不全に起因する 㓣感染が大半を占めた，胃全摘術では，肺炎，晹炎， 啭合不全に起因する腹峔内感染が関与し，胃切除術で は，腸炎の占める割合が高かった。結腸・直晹手術で は, 腹腔内感染，剖感染の占める割合が高かったが， 肛門似の大腸ほど, 会陰㓣のあるものほど術後感染症 の発症事が高かった。

起因菌の湌討では，MRSAについては1989年5月に初 めて分攵され，毎年 5〜 7 月の梅雨時期に食道・胃疾 悬術啳に渴炎型，肺炎型として多く発症している. 1990年後半より使用抗生物定を限定し, 予防と早期発 見・早期治痖に努め重症化例は減少したが, 発症事の 激滅には到っていないのが現状である.これに対して，

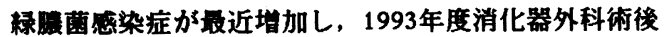

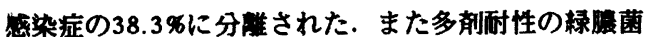
も出現し，粶滕菌の肺炎，腹腈内感染による死亡例も 契められており，MRSAのほかに粶獧菌対する暗切な 対応の必要性がせまられている。

消化器外科術後感染症は抗生物䖯の発達した現在で も頖度の高い術後合併症の 1 つであり, 手術成績を左 右する而大因子である. 当院における遇去 5 年間の消 化器外科術後感染症について湌討した。

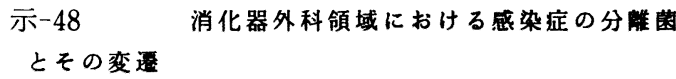

名古屋市立大学第一外科、机幌医科大学第一外科 '、

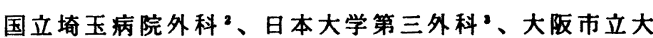
学第二外科 ‘、和歌山県立医科大学消化器外科 ‘、岡山 大学第一外科 、広岛大学総合診痖部'、福岡大学第一 外科・、東京総合臨床検查センタ一研究部・

品川長夫、真辺忠夫、平田公一 ${ }^{2}$ 、石引久弥 2 、

田中隆”、木下博明“、谷村弘”、折田羔三”、

横山隆?、山本 博・、出口浩一’

[目的]消化器外科領域では、穿孔性腹腃炎、胆震炎 ・胆管炎などの一次性感染症と手術創感染、腹璄内脿 癔などの手術後にみられる術後感染症が問題となる。 原因菌の多くは腸内細菌由来であるが、メチシリン耐 性黄色ブドゥ球菌（M R S A ）など院内懪境由来のも のむおる。理論的な抗菌化学癔法を施行するには感染 症分離菌の現況を把暒する必用がある。

[対象と方法] 1982年6月より全国 9 大学病院および その関連施設において、消化器外科領域感染症病柴よ

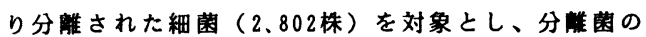
年次的な変票、薬剂感受性および患者側の背景因子に ついて検討した。

[成績]腹膜炎などの一次感染症より1,349格が分噰 された。E.coli、嫌気性菌、Klebsiella spp.などの 分離頻度が高く、年次的な大きな变邆はみられなかっ た。一方、術後感染症よりの分蜼菌については大きな 変歷がみられた。すなわち、Staphylococcus spp.の 分離頻度は1985年度より年々增加の傾向を示してきた が、M R S A の分離頻度が高くなったのは1987年以降 であった。しかし、最近の 1 年間でのブドゥ球菌の分 離率は低下し、Enterococcus spp.の分踓率(18.3x)に ついで第 2 番目の分離率(15.7\%)となった。Pseudomon as spp. は $10 \sim 20 \%$ の分離頻度でほほ横這いの状 態であった。急激に增加したEnterococcus spp.の分 離率は 1988 年度以後では約 $10 \sim 15 \%$ の分離頉 度と低下したが、最近の 1 年では再び增加した。嫌気 性菌ではB.fragilis groupの分離率が高かったが、年 次的な変動は少なく8〜15\%の分部率であった。 抗菌剂が投与された後に分噰される細菌は、Enteroco ccus spp.. Staphylococcus spp.. Pseudomonas spp. などが多かった。嫌気性菌やE.coli，K1ebsiella spp. などの分踓頻度は低いが、これは抗菌剂の効果が大き いためと考えられた。VCM耐性のM R S A はられな かったが、ABK耐性株は4/107株（3.7\%) みられた。 [結語]一次感染症では従来からのE.coli， Klebsiel la spp. および嫌気性菌の分崔頻度が高く、術後感染 症ではまだM R S A とPseudomonas spp.の問題が続く と考元られた。これらの細菌の分離率はいくつかの背 景因子と相関していた。 
示-49消化器外科手術後の methicillin-resistant Staphylococcus aureus 腸炎予防における周術期バンコマ イシン経口投与の意義

\section{国立福岡東病院 外科}

島田光生、斎藤 純、狩野 律

【目的】近年、消化器外科領域におりて㭪後の methicillin-resistant Staphylococcus aureus (MRSA) 腸 炎は最子重大な術後合併症の一つとなっているるのの、 MRSA腸炎予防に関する有効な報告はこれまでない。 今回、術後 MRSA腸炎予防における周術期のバンコマ イシン ( VCM) 経口投与の意義につんて愉討した。

【対象および方法】1993年 4 月〜 9 月までの 6 ケ月 間に当科で待期的消化器外科手術を施行した 64 例を VCM投与群 $(n=13)$ および対照群 $(n=51)$ に分け愉

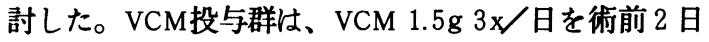
前より術日早朝まで投与したのち、術後 1 〜 2 日まで 経口あるいは経管的に投与した。緊急手術およびイレ ウス解除は愉討から除外した。患者は原則として入院 時に、鼻腔、喀痰、便の細菌培養同定を行々 MRSAの carrierを screeningするとともに、術後は便培養および 便中の Clostridium difficile (CD) 抗原のチェックを施 行した。術後MRSA腸炎発症患者では MRSAの薬剂耐 性型、コアグラーゼ型、トキシン型を同定した。

【結果】背景因子の比較では VCM投与群の年制か対 照群に比し高秢であることと術後の第 2 あるいは第 3 世代セファロスポリン系抗生物質使用が少なかった。 MRSA腸炎およびその他の MRSA感染症の発症率に関 しては、VCM投与群においてはいずれも皆無であった のに対して、対照群におらては MRSA腸炎 7/51(13.7 \%) およびその他の MRSA感染症 11/51(21.6\%) であ った。術後合併症の比較では、対照群に合併症の発生 率が高々傾向にあった $(17 / 51$ vs. 3/13)。 また、対 照群では CDによる腸炎発生例を 1 例認めたが、VCM 投与群では認めなかった。術後 MRSA腸炎発症患者の 特街は、術前の抗生物質を用いた腸管前処置が多く、 胃切除や H 2-blocker 使用は少なかった。また、術後倹 出された MRSAの特幑は、薬凧耐性では VCMとABK のみ感受性を有する高度多剂耐性型が多く、コアグラ 一ゼ型では II型、トキシン型では TSST-1(十)であっ た。VCM投与による副作用は認めなかった。

【考察ならびにまとめ】術後 MRSA腸炎に関して、 MRSA腸炎の危険因子である胃切除術や H 2-blocker の使用などが必ずしも多くないこと、またMRSAの特 幑として TSST-1(+)であり高度多斉耐性株が多いこ とは警鐘に值する。また、VCM投与群におんて CD腸 炎の発生を認めなかったことも注目すべを点である。 今回の倹討から、周術期 VCM 経口投与は消化器外科手 術後 MRSA腸炎ならびに薬剂性腸炎予防に極めて有用 であることが示唆された。
示 -50

\section{術後MRSA腸炎に䦎する実䀫的検討}

名古屋市立大学医学部第一外科

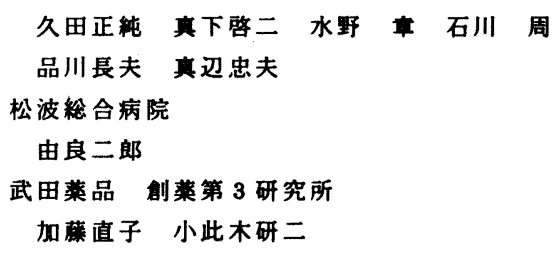

（目的）胃切除術をはじめとする上部消化管手術後に 好発し、消化管内でメチシリン耐性Staphylococcus a ureus（MRSA）が急激に增加して起こるMRSA腸炎は、 一種の首代性渴炎である。かが国では1985年頃から 報告され始め、MRSA感染庭のなかです最す重籊な感染 症のひとつとなっている。MRSAは健康人においてさえ

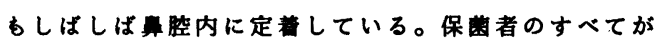
MRSA腸炎を発症するわけではないが、MRSA腸炎は䒚腔 から移行して腸管内に定着した菌が原因となって起こ る可能性が高い。そこで、マウスを用い算䐥内に接種 したMRSAの盲晹内への移行・增殖に及ぼす諸因子の影 简を調べた。

(対象と方法) ICRマウス（オス・5週峆）の㓐内に $10^{\circ} \mathrm{CFU}$ のチシリン耐性 Staphylococcus aureus N133 (MRSA N133)を接種し、各種要因下（一群5匹）におい てその首腸内定着菌数を矵定した。

（結果）感染 3 時間後には目腸内に約 $10^{5} \mathrm{CFU}$ 検出され、 1 日後に $10^{3} \mathrm{CFU} 、 3$ 日後に $10^{2} \mathrm{CFU}$ と娍少したが、5日後 には再び $10^{3} \mathrm{CFU}$ 近くまで增加し10日後すほぼその娄数 が維持された。

感染前後に20 mg/kgのanpicil1 inを1日2回4日間皮下投 与すると、MRSAの盲晹内での增殖がやや促進されたが、 cefotianではやや抑制され、cefozopranでは增殖が完 全に阻止された。また、cyclophosphamideを感染3日 前に $200 \mathrm{ag} / \mathrm{kg}$ を腹臆内投与するか、または盛染1日前 にdexamethasoneを $200 \mathrm{mg} / \mathrm{kg}$ 皮下投与して免疫能を低 下させておくか、感染直後に単開腹手術を行ないスト レスを与えておくと、盲晹内でのMRSAの增殖が促進さ れた。一方、感染前にEnterococcus faeciunを释口投 与しておくと単開腹手術によるMRSAの直腸内增殖の促 進が抑制された。

（考察と結語）以上の結果から抗生物贫が必ずしるMR SAの盲晹内での增殖を促進するわけではなく、むしろ 免度能の低下や、手術などによる多大なるストレスの 影需のほうが大きいことが示唆された。また術前に腸 管からMRSAが検出された店例では期terococcus faeci

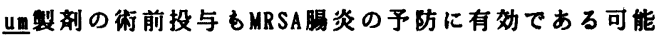
性が示唆された。 
示-51消化器癌に対する in vitro 制癌剤感受 性試験 一SD I 法とATP法の比較を中心に一

帝京大学第 2 外科

矢後岳志, 冲永功太, 飯沼久恵, 治部達夫

【目的】個々の消化器癌患者に対するより有効で安 全な化学療法を目的として in vitro 制癌剤感受性試 験である SD I 法とATP 法の臨床応用を試み, 両者の 感受性結果を比較検討した。

【対象之方法】胃癌 9 例, 大腸癌 7 例, 計 16 例を対 象とした。腫瘍細胞は原発部および腹水より採取した。 SD I法は山内らの方法に準じMTTを用いて行った。 細胞内 A T P 量はルシフェラーゼを用いたバイオルミ ネッセンス法にて行った。制癌剤は mitomycin ( MMC), 5-Fluorouracil $(5-\mathrm{Fu})$, adriamycin ( ADM), cis-Diamminedichloroplatinum ( CDDP ), methotrexate (MTX)を使用した。各薬剤濃度は MMC $(30 \mu \mathrm{g} / \mathrm{m} \ell, 10 \mu \mathrm{g} / \mathrm{m} \ell, 1 \mu \mathrm{g} / \mathrm{m} \ell), \mathrm{ADM}(30 \mu \mathrm{g}$ $/ m \ell, 10 \mu g / m \ell, 1 \mu g / m \ell), \operatorname{CDDP}(50 \mu g / m \ell, 25 \mu g /$ $m \ell, 10 \mu g / m \ell), 5-\mathrm{Fu}(100 \mu \mathrm{g} / m \ell, 50 \mu \mathrm{g} / \mathrm{m} \ell, 25 \mu \mathrm{g} / \mathrm{m} \ell)$, $\operatorname{MTX}(75 \mu \mathrm{g} / \mathrm{m \ell}, 15 \mu \mathrm{g} / \mathrm{m \ell}, 1.5 \mu \mathrm{g} / \mathrm{m \ell})$ とした。いずれも 3 日間培㙩後Inhibition Index を求め, 薬棛の効果判定 は50\%以上を有効とした。臨床効果での判定は, 日本癌治 療学会の定めた固形癌化学療法直接効果判定基準によった。

【結果】SDI法を用いたときの薬剂別の有効率は，胃癌 原発部腫瘍細胞においてMMC 25\%, 5-Fu 25\%, CDDP 25\%, ADM 33\%, MTX 25\%であり胃癌腹水中腫瘍細胞 においてMMC 33\%, 5-Fu 33\%, CDDP 33\%, ADM 33 $\%$, MTX 0\%であった。さらに大腸癌原発部腫瘍細胞で はMMC $33 \%, 5-\mathrm{Fu} 33 \%, \mathrm{CDDP} 33 \%, \mathrm{ADM} 0 \%, \mathrm{MTX}$ 0\%を, 大腸癌腹水中腫堭細胞ではMMC $0 \%, 5-\mathrm{Fu} 0 \%$ 。 CDDP67\%,MTX 0\%を示した。またATP法を用いた 時の各薬剂別有効率は胃癌原発部腫瘍細胞でMMC 33\%, 5 -Fu 33\%, CDDP 75\%, ADM 50\%, MTX 0\%, 胃癌腹 水中腫場細胞でMMC 67\%, 5-Fu 33\%, CDDP 67\%, ADM 67\%, MTX 0\%であった。さらに大腸癌原発部腫場 細胞ではMMC 33\%, 5-Fu 33\%, CDDP67\%, ADM67 $\%$, MTX 0\%を, 大腸癌腹水中腫瘍細胞ではMMC $50 \%$, 5-Fu 0\%, CDDP 50\%, MTX 0\%を示した。次にSDI とATP法の薬阂感受性の一致率を比較するとMMC 60\%, 5-Fu 60\%, CDDP 60\%, ADM50\%, MTX80\%, 平均 して 62\%を示した。また同一症例の原発部と腹水腫崵細胞 で, 薬剂感受性の結果が異なる症例が認められた。さらに 薬剤感受性試験に基ついた制癌剤投与ではリンパ節再発の 2 例に効果を認め, 5-Fu, ADM, MMC を併用した 1 例 はCRを示した。【考察】消化器癌原発部腫瘍および腹水 腫瑝細胞を用いて, SDI法とATP法を比較検討した。るの 結果, 各薬剤に対する感受性一致率は平均して $62 \%$ \%ちっ た。また同一症例の原発部と腹水で感受性の結果が異なる 症例も認められ, 制癌剂の標的部位をサンプルとして, 感 受性試験を行う必要性も示唆された。

\section{示-52制癌剂抗体による副作用中和と制癌剤薬 効作用增強の実験的研究}

東海大学医学部附属大磯病院外科、附属病院、 附属東京病院

中崎久雄、太田正敏、渡辺敏輝、田島知郎、三富利夫

\section{[目的]}

一般的には制癌剂効果は投与量に比例し薬効が增加 するが、投与量の増加と共に副作用も增大し、背反す る二面性が認められる。現行の制癌剂の single rapid infusion 投与方法の効果を一層高めるために制癌剤の 抗体を作製し、その薬効を経時的に、意図的に中和し、 副作用の軽减と制癌剂薬効作用増強を目的とした実験 を行った。制癌戍としてアドリアマイシン (ADM)を 用い、AADMによる骨蹎及び心裁におよぼす副作用の 軽減と抗体使用による制癌剂効果について報告する。

\section{[実験方法]}

(1) ADM 抗体の作製 : 家鬼に ADM を免疫して抗体 を作製する。(2)抗 ADM 抗体を用いて癌細胞内の投与 された ADMの局在を免疫組織学的に検討する。(3)抗 ADM 抗体使用によって ADM の心筋及び骨跹機能に 及ぼす副作用軽減化をの検討する。(4)腫煌移植マウス の ADMによる治療における抗 ADM 抗体の制癌剂薬 効増強を検討する。

\section{[実験結果]}

(1)抗 ADM 抗体は癌細胞内の ADM の局在を認めた。 (2)抗 ADM 抗体による免疫組織化学的検討で ADMに 感受性の高い腫瘍系では細胞質および核に ADM の集 積が著明であることを認めた。(3副作用の検討で心筋 の萎縮は投与 $\mathrm{ADM}$ 量に比例するが抗 $\mathrm{ADM}$ 抗体投与 によって心筋の萎縮は軽減された。骨餚機能の検討で はリンパ球、血小板数は抗 ADM 抗体の投与によって 機能低下が軽減された。(4)腫瘍移植 ddy マウスに対し て ADM 投与による治療を行った。ADM 単独投与群 に比較して ADM および抗 ADM 抗体投与群は有意の 治療効果が認められた。

\section{[結論と考察]}

抗 ADM 抗体投与による ADM の薬効の急速中和は 骨鲔、心筋などの重要臟器に対する副作用を軽減する ものである。このことは制癌剤効果を高めるための投 与量の增加を高める可能性を示唆する。また腫場細胞 の薬剂耐性発現までの時間内に繰り返し投与の可能性 をも示唆する。

\section{[今後の研究]}

これら一連の実験で用いた抗体はポリクロナール抗 体であるがより特異性の高いモノクローナル抗体の作 製を検討中である。ADM以外の制癌剤：5- Fu の抗 体を作製し実験中である。 
示 -53

高エネルギー街盤波の癌治療への応用と

その発展

\section{千葉大学第 2 外科}

丸山通広、浅野武秀、榎本和夫、植松武史、 中郡聡夫、所 義治、長谷川正行、神宮和彦、 松井芳文、宮内英聡、岩下 力、磯野可一

【目的】高エネルギー衝繋波（HESW）は、現在尿 路結石や胆豪結石の治療法として確立しているが、 我々はその抗腫場効果に注目しており、研究を進的て きた。HESWは副作用も少なく綝り返し施行し得るた め、瘭局所治療に有効ではないかと考える。しかし今 までの検討ではHESW単独での抗腫場効果は十分とは いえず、その効果を增強させる因子が必要である。そ こで、抗癌郕としてシスブラチン、及び光増感郕であ るポルフィリン誘導体のATX-70, Fe-TPPSとの併用効 果を検討し、さらにHESWの有効照射法を検討した。

【方法】衙慗波発生装置は結石治療に使用している EDAP社LT-01を用い、実験腫晹にはマウス肝症である MH134を用いた。「in vivo実験」マウス後肢大腿皮 下にMH134を移植し、腫覆径が約 $7 \mathrm{~mm}$ になったもの に薬剂投与後HESWを照射し、腫㨽増殖抑制効果を検 討した。「in vitro実験」MH134の睤濁液を作成し、 $5 \times 10^{6}$ cell/0.5mlを Polypropyrane Tubeに充填、薬郕混和 後各種条件にてHESWを照射し、照射直後の腫場細胞 生存率を測定した。

【結果】in vivo実験ではシスブラチン、Fe-TPPS と の併用効果を認めた。in vitro実験では、ATX-70との併 用効果はFe-TPPSより強力で、ATX-70と併用すること により、生存率がHESW単独 $41 \%$ 、併用 $11 \%$ と著明に 減少した。またHESWの抗腫境効果やATX-70との併用 効果はHESWの周波数、照射 1 回あたりの出力等の条 件には影鳘されず、総投与エネルギーに依存した。シ スブラチンとの併用では照射直後の併用効果は認めら れなかった。

【まとめ】シスブラチンとの併用効果はHESW照射 直後に現れるのではなく、腫謿が増殖していく際にみ られることがわかった。ボルフィリン誘導体との併用 効果は、HESW照射によりポルフィリン誘導体が抗腫 湯活性化することによるものと考えられた。従来のレ 一ザー等を使用した光化学療法は体表や粘膜面に限ら れており、HESWを用いれば体深部の治療も可能にな るものと考えられる。今後はHESWの効果增強郕を各 種検討し、臨床応用へと発展させていきたい。
示-54消化器癌手術での輸血の特徴と自己血輸血 について

埼玉医科大学総合医療センター第二外科 ${ }^{1)}$, 同輸血部2)

藤野幸夫 ${ }^{1)}$ ，村田宣夫 ${ }^{1)}$ ，人見祐子 ${ }^{2}$ ， 前田平生 ${ }^{2)}$, 遠山 博 ${ }^{2)}$

[目的] 自己血輸血は，すでに，心血管外科や整形外科 領域で, 同種血輸血の回避・削减のために広く行なわれ ている。それらに比へ，消化器外科領域での自己血輸血 の適用は遅れている。その理由は, 種々考えられるが, 今回, 消化器癌手術での術中輸血の特徴をまとめ, 消化 器外科領域での自己血輸血の施行方法についてわれわれ の考えを示したい。

[方法]根治手術が行われた胃亜全摘出術(SG), 胃全摘出 術( $(T G)$, 結晹切除術(COLE)，低位前方切除術(LAR), 直晹切 断術（Niles）について1987年から1989年までの症例をA 群(200例), 眝血式自己血輸血を開始して以後の1991年か ら1993年の症例を B群 (199例) として術中同種血輸血症 例での輸血量について検討した。自己血眝血の適応基準 は, 予想出血量 $600 \mathrm{~m} 1$ 以上の待期手術患者で, 年齢 70 歳以 下，体重50kg以上、へモグロビン值 $11 \mathrm{~g} / \mathrm{d} 1$ 以上の症例と した。貯血方法は，術前 4 から21日前に $400 \mathrm{ml}$ 採血し，そ の後、へモグロビン值が $11 \mathrm{~g} / \mathrm{d} 1$ 以上あり, $800 \mathrm{~m} 1$ 以上必要 と考えられる症例は，さらに400m1採血した。

[結果] 術前へモグロビン值が $11 \mathrm{~g} / \mathrm{d} 1$ 以上で, 同種血輸 血を受けた症例の輸血量を調べてみると, $800 \mathrm{~m} 1$ 以下の症 例の割合は, SG:83\%(5/6), TG:67\%(12/18), COLE:92\% (11/12), LAR: $80 \%(4 / 5)$, Miles:56\%(5/9) で, 合計74\% (37/50)であった。A群で, 術中に同種血輸血を受けた割 合は, SG:20\%(16/79), TG:61\%(22/36), COLE:41 \%(21/ 51), LAR:50\%(9/18), Miles:75\%(12/16), 全体で $40 \%(80$ /200)であった。B群での同種血輸血は, SG:11\%(8/74), TG:31\%(12/39), COLE:22\%(10/46), LAR:17\%(4/24),

Miles: $31 \%(5 / 16)$, 合計20\%(39/199)とA群に比べ, 有意 に低下していた $(\mathrm{P}<0.01)$ 。自己血輸血が行なわれたの は, B群で, SG:10例, TG:14例, COLE:8例, LAR:11例, Miles: 5 例, 合計48例, 平均眝血量 $445 \mathrm{ml}$ であった。その うち同種血輸血を併用したのはTG：2例とMiles：2例だ けであった。濃厚赤血球液の総使用量は, A群で339単位, B群で126単位で, 同種血輸血を受けた症例では, A群で 平均 4.3 単位, B群で平均 3.2 単位を受けていた。

[結論] 胃癌, 大腸癌などの消化器癌手術において, 術前 へモグロビン值が $11 \mathrm{~g} / \mathrm{d} 1$ 以上で, 術中同種血輸血を受け た症例の大部分が, 800m1以下の輸血量であった。このこ とは, 消化器外科領域では, $800 \mathrm{~m} 1$ の自己血眝血で, 大半の 症例が, 同種血輸血を回避できることを示唆している。わ れわれの経験では，400m1から800m1の貯血式自己血輸血 を実施することによって同種血輸血が, 有意に減少した。 


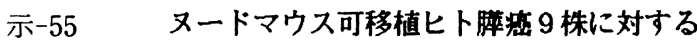
制㽾削感受性の検討

\section{鹿北島大学第一外科}

坪内斉志 高尾尊身 植村勝男 有留邦明 松山義人 今村 博 山田一隆 要甲 孝

[目的］桠渱では、外科的切除のみではいまだ浦足 しうる成績が得られず、化学療法は、放射線療法とと もにその集学的治療の重要な役割を担っている。今回、 教室で移植、継代中のヌードマウス可移植ヒト膡癌 9 株の種々の制湾削に対する感受性を調べ、その特徴を 検討したので報告する。

[方法 ] 对象は、教室で移植、継代中のヌードマウ ス可移植ヒト脺癌 9 株、および Cell Line ; HeLa,KatoIII, JHP-1とした。使用薬削およひ菜削瀑度は、CDDP (50 $5 \times 10^{4} \mathrm{ng} / \mathrm{ml}$ ), MMC ( $50 \sim 5 \times 10^{4} \mathrm{ng} / \mathrm{ml}$ ), ADM $\left(10 \sim 1 \times 10^{4} \mathrm{ng} / \mathrm{ml}\right), 5-\mathrm{FU}\left(5 \times 10^{2} \sim 5 \times 10^{5} \mathrm{ng} / \mathrm{ml}\right.$ )で、接触時間は72時間とし、MTT - Assay にてその 抑制率を求めた。

[結果] ヌードマウス可移植ヒト膤痖 9 株は、対照 とした 3 種の Cell Line よりも全体的に低感受性であっ

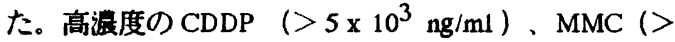
$\left.1 \times 10^{3} \mathrm{ng} / \mathrm{ml}\right) 、 A D M \quad\left(>4 \times 10^{2} \mathrm{ng} / \mathrm{ml}\right)$ では $95 \%$ 以上の高い抑制率が得られたが、5-FUは、9株中

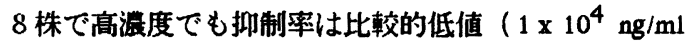
で 15〜30\%) であった。一方、低㳻度の CDDP（く $\left.2 \times 10^{2} \mathrm{ng} / \mathrm{ml}\right) 、 \mathrm{MMC}\left(<1 \times 10^{2} \mathrm{ng} / \mathrm{ml}\right) 、 A D M($ $<40 \mathrm{ng} / \mathrm{ml}$ ) では、すべての薬削で浦足しうる抑制率 は得られなかったが、5 - FUは他の菜绪と比較して、 低浱度では逆にやや高い抑制率 $\left(5 \times 10^{2} \mathrm{ng} / \mathrm{ml}\right.$ で 30 $84 \%$ ）を示す傾向が認められた。

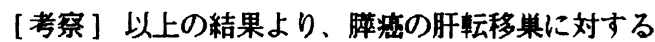
動注療法等、高浱度の菜绪被爆が得られる場合は、化 学療法による治療効果が期待される。しかし、满浩の 原発果において高い血中湿度を長時間得ることは解剖 学的な理由等から困難で、今回テストした 9 株につい ては、化学療法単独では十分な成果が得られないこと が予想された。また低浱度では、5-FU が他の薬绪と 比較してやや高い抑制率を示したことは、臨床上同郕 が有効であったとするいくつかの報告を哀付けている 可能性が示唆された。電痁に対する集学的治療におい て、化学療法は重要な设割を担っていることは言うま でもないがその効果は十分とは言い難く、原発果およ び転移临別にその投与菜绪、投与方法を検討する必要 があると思われた。
示-56 免疫抑制剂投与と膵機能異常

名古屋第二赤十字病院 移植外科、名古屋大学

医学部 第二外科

片山昭男、横山逸男、打田和治、富永芳博、

林 衆治、大塚聡樹、佐藤榮作、安冨元彦、

䄈宜田政隆、小池千裕、高木 弘

[目的] 荿器移植後の荤機能障害（高アミラーゼ血症） の病態については未だよく理解されていない。肝移植 後の原因不明の膆炎と B 型肝炎ウィルスの関連を示唆す る報告もあるが、腎移植後の茦機能障害については詳 しく理解されていない。慢性腎不全患者では二次的な 高アミラーゼ血症がみられることが多く、移植腎機能

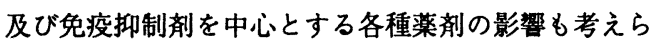
れる。今回我々の死体堅移植症例の経験に基づき、移 植後の脞機能障害と特に肝機能異常との関連について 調べた。［対象及び方法］死体堅移植患者 95 名の術前、 術後 1 週間及び 1 ケ月後の腎、肝、荤機能そして肝炎 ウィルスに関する血清学的検査も行った。免疫抑制療 法はシクロスポリン（CsA）及びステロイドの混合療 法にアザチオプリン（Az）を追加した三者併用療法を 行った。CsAの投与量は移植腎の機能程度に応じて決 定し、Azは $2 \mathrm{mg} / \mathrm{kg} / \mathrm{d}$ を 2 週間投与した。［結果］術 前、高アミラーゼ血症を示した症例は $50 \%$ 以上に認め られたが、その多くは術後次第に正常化した。全体の 約 $25 \%$ の患者は術後高アミラーゼ血症を呈した。しか し臨床的に荤炎を示したのは 1 例にすぎなかった。一 方術後トランスアミナーゼの高值（50 IU/L 以上）を示 した症例は約 $25 \%$ に認められ、これらの患者では同時 に高アミラーゼ血症（平均＝710 IU/L）を伴い、肝機 能異常を示さなかった患者に比べて有意に高値であっ た。逆に持続性高アミラーゼ血症を呈した患者の半数 以上にトランスアミナーゼの高值が認められた。B型 肝炎ウィルスキャリアは 1 名存在したが、肝あるいは 脺機能異常はみられなかった。C 型肝炎ウィルス抗体 陽性者は 20 名に認められ、有意差はないものの術後高 トランスアミナーゼ血症を呈した患者群に多く見られ る傾向があった。しかしながら肝及び媵機能異常を示 したいずれの患者も予後は良好であった。［考察］高 アミラーゼ血症の原因は不明であるが、肝機能異常と の関連が強く示唆された。肝機能異常は免疫抑制剂で ある Az の肝毒性、あるいはステロイド大量投与後にし ばしばみられることもあり、さらに C 型肝炎ウィルス の関与も考えられる。免疫抑制郕の荤外分泌機能に対 する直接的な影響よりはむしろ肝機能障害に続発する 膵への影謷、例えば一過性の門脈圧上昇などの病因も 考虑に入れるべきであろう。しかし肝移植後にみられ る肝炎ウィルス（特にC 型）と脺炎の関連については 明らかな相関はみられなかった。 
示-57 イヌ膵移植における温阻血再灌流障害と nafamostat mesilateの効果

京都府立医科大学第 2 外科

清水義博、山岸久一、中井一郎、小田俊彦、

満尾 学、森田修司、内山清、岡 隆宏

広島大学第 2 外科

福田康彦、土肥雪彦

（目的）心䑅停止後の移植膵摘出では温阻血障害は 不可避であり、この過程で生ずる䑏器障宫をいかに軽 減するかが移植初期の臨床成績を向上させるうえで大 きな課題となる。今回我々は、nafamostat mesilate （以下NM）リンス液のイヌ膆温阻血に対する保護効 果を実験的に検討した。（方法）雄雑種成犬を用い た顏部への膵体尾部自家膵移植モデルにより検討した。 膵摘出後、直ちに $37^{\circ} \mathrm{C}$ のンキュベーターのなかで 同温のEuro-Collins液で 5 分間灌流した。同液中・ 同温で 60 分間漫漬保存、約 10 分間リンス液を流した あと血管吻合、血流再開とした（総温阻血時間90分）。 対照群ではヘパリン加生食、NM群ではNMリンス液 により移植前リンスを行った。移植後、経時的にプロ スタグランジン関連物兵としてTXB2、フリーラジカ ル関連パラメーターとして $\alpha$-tocophelol,TBAを末梢 血とグラフト静脈血で測定するとともに、NMの移植 膵組織濃度を測定した。（結果）対照群では肉眼的、 組織学的にほぼ不可逆の壊死性变化をきたしたのに対 し、NM群では軽微な浮腫を示すのみであった、フリ ーラジカル関連パラメーターは両群間で顕著な差を認 めなかった、TXB2をみると、NM群においてその産 生抑制が特にグラフト静脈血に顕著な傾向が認められ た。(体静脈血：3000 pg/ml、グラフト静脈血： $1200 \mathrm{pg} / \mathrm{ml}$ ）膵組織中の未变化体 NM濃度は血流再開 前で12.95 $\mu \mathrm{g} / \mathrm{g}$ tissue とかなり高值であり血流再開 後 3 時間後まで高濃度でかつ未变化体比率に著变なく 残存した（表 1)。(考察) 形態学的にNM群では膵 温阻血障害が軽減されていた。NMの組織内移行およ び血流再開後の残存は十分であり、NMがホスホリパ 一ゼA2を阻害してアラキドン酸の遊離を抑制したこ とが移植膵保護の一作用機序と推察された。

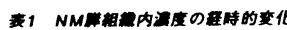

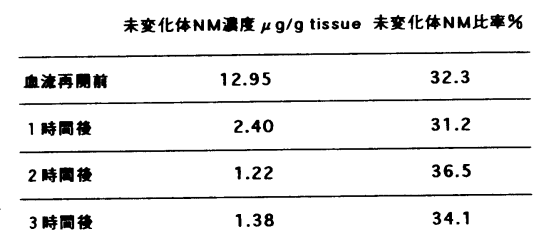

示-58 器械繾合器と吸収性ポリグリコール酸 フエルトを用いた捇体尾部切除の新しい方法

埼玉医科大学第 1 外科

小山 勇、安西春幸、長島直樹、㢦崎敏郎、松本 隆、 田口 泰、山崎達雄、尾本良三

粗体尾部切除を伴う胃癌の根治術は広く行われてい る手術法であるが、一方で、術後膆液璂の発生はとき に腹腔内脤瘍や出血などの重大な合併症を引き起こし、

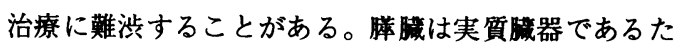
めに、断端の主䐙管のみを処理しても、その他の微細 な分泌管の処理は原理的に完全に行うことは不可能に 近い。いかに術後の膵液漏出を減らし、難治性の胘液 瘦の発生を予防するかは、重要な課題である。我々は、 腣体尾部切除における腣液漏出を予防する方法として、 単純に器械繾合器により閉鎖する方法を1986 年よ り採用してきた。この方法では、従来の手繾い法に比 へ、有意に膵液瘦の発生が減少したが、膀組織が脆弱 な場合には、いまだ満足のいく結果が得られていない。 そこで、今回われわれは、吸収性フェルトをとともに 器械縫合器を用いて䐙切除を行う方法を新たに試みて いるので紹介する。

[方法] 脾静脈を結禁後、切除ライン上に吸収性ポリ グリコール酸フェルトを全周性に巻き、その上から TA55を用いて腪を切離する。膵断端はフェルトととも に、ステープラーにて両側から押さええられている。 断端のフェルト間をプロリン糸で縫合し、断端を閉鎖 する。最後に、断端をフィブリン糊で覆った。

[結果] 5 例に行ったが、荤液瘦は 1 例も認められず ドレーンからの排液もほとんど認めなかった。また、 器械繾合器のみの時に経験した断端からの出血も全く 認められなかった。

いまだ、症例数が少ないが、本方法による苇断端の 処理はきわめて簡便で安全な方法と思われたので、そ の方法をビデオにて供覧する。 
示-59 膡島細胞腫暍再発症例の検討

広島大学第 2 外科

田中恒夫、真次康弘、小出 圭、三浦義夫、市場康之、 岡島正純、小野栄治、八幡 浩、浅原利正、福田康彦、 土肥雪彦

【はじめに】膵島細胞腫㾇手術症例のうち多くは経過 良好でるが、術後に再発や転移などをきたし治療に難 泶することも経験する。そこで、当科における膆島細胞 腫病手術症例のうち再発や転移なとをきたした症例を検 討した。

【対象、成績】Insulinoma は 11例中2 例に、ZollingerEllison syndrome (ZES) は 4 例中 2 例に、再発（転移）を 認めた。非機能性腫瘦は 2 例とも経過良好であった。

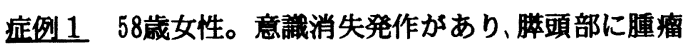
影を認めたので insulinoma と診断した。術中には単発の 腫瘤のみを認めたため、腫瘦摘出術を行った。摘出後の 血糖値の上昇は認められたものの、不良であった。術後 3 カ月後には低血糖症状をきたした。そこで再手術を行っ たところ、膵体尾部に 10 個以上の腫瘦を認めたので、 80\%膵体尾部切除術を行った。病理学的には adenom a であった。その後の経過は良好である。

症例2 45 歳女性。既往歴: 下垂体腫癔。膵体部に腫 痹影を認め、術前 insulinoma と診断した。60\% 膵体尾部 切除術を行ったところ脇体部に 2 個の腫㾇を認め、血糖 值も上昇した。しかし、術後 2 週目には低血糖症状を きたし、術後 3 カ月目には画像上、膵頭部に径 $2 \mathrm{~cm}$ 大の 腫瘫影を認めた。腫瘤の増大傾向はなく薬物療法にて血 糖をコントロールし、経過観察中である。

应例 343 歳男性。門脈サンブリンクにて膵体 部にガストリンの高值を認めたが、画像訩断では腫病は 認められなかった。80\%膵体尾部切除術、胃全摘出術 を行ない、病理学的には carcinoidであった。術後ガス トリン值は正常化したが、術後 1 カ月目より再上昇した。 2 年後にはACTH産生胸腺腫曒を発症し、胸腺摘出術を 行った。病理学的には carcinoidであった。肺転移をき たし Cushing syndromeを呈した。初回手術より3 年10力 月後に死亡した。病理解剖にて残存䐗、十二指晹に脺 carcinoid の再発を認めた。

症例4 47 歳男性。ZES。門脈サンフリングにて勝頭 部にガストリンの高值を認めたが、画像診断では腫鸱の 局在は明らかではなかった。勝頭十二指腸切除術、胃要 全摘出術を行ない、十二指晹第二部に粘膜下腫孩を認め た。病理学的には carcinoid であり、膆周囲のリンパ節 転移を認めた。術後 3 年目に肝転移をきたし、萊物療法 にてfollow-up 中である。

【結語】 insulinoma でも術後早期に再発するものがある。 転移、再発した ZES の治療は容易ではない。
示 -60

膡癌との鑑別が困難であった膆腫瘦性病

変の検討

大阪市立大学第 1 外科

山下好人，矨容錫，西野裕二，仲田文造，

平山晃司，乾嗣昌，奥野匡有，曾和融生

[目的]各種画像診断の発達に伴って, 膵癌の診断 能は向上したが, 一方では膆癌類似の腫痹を形成した 良性病変も多く発見されるようになった．今回，過去

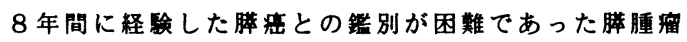
性病変について検討したので報告する.

[対象症例] 教室で $1986 \sim 1993$ 年の 8 年間 に経験した膵腫瘦性病変を対象とした。その内訳は膵 癌が 86 例, 膡癌の疑いにて紹介された慢性勝炎いわ

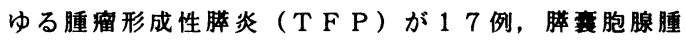
が 6 例（粘液性 3 例, 墏液性 3 例）, 勝仮生衰胞およ び貯留莗胞が 16 例であった。

[結果] T F P と勝瘄：TF P との爁別が問題とな る $\mathrm{T}_{1}, \mathrm{~T}_{2}$ 膵瘦 26 例を比較㛟討した。 T F P は男 性に多く，発症年龄は膵㾴：62.0 歳, T F P : 5 3.1 荿で, T F P の飲酒歴, 血清アミラーゼ値上年 の頻度は膆癌より有意に高かった，TF P ならびに膆 癌の主訴と腫瘦局在部位について検討すると、 $\mathrm{T} 1$, $\mathrm{T} 2$ 膆癌は膆頭部に黄㾝で発見されることが多く、 $\mathrm{T}$ F P においては黄㡺例は認めないものの膆頭部に多か った. T F P の診断は, 17 例中 9 例が何らかの画像 検㚗で膡癌と診断されていた。個々の画像検直におけ る膆癌の診断率は, E U S, 超音波, E R C P , C T の順に高かったが, 同時に T F P を膆癌と診断するこ とも多く，個々の検査だけでは満足できる診断率は得 られなかった，畽离マーカーによる T F P と勝密の鑑 别においては，SPan-1 抗原ならびにCA19-9 の cut of $\mathrm{f}$ 値を $100 \mathrm{U} / \mathrm{ml}$ とすることにより高い正診事が得 られ，経時的測定も有用であった。

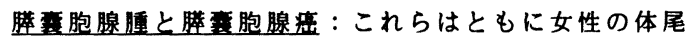
部に多く, 繁液性毫胞腺腫の診断は比較的容易であっ たが，粘液性衰胞腺腫と衰胞腺㾔の鑑別は内部に突出 する隆起病変などを参考にするものの, 進行した症例 を除いて，その爁别は困難であった。また腫渴マーカ 一による両者の鑑別も困難であった，膵仮性㗑胞なら びに詝留毫胞：滕仮性言胞ならびに詝留衰胞の診断は， 隔壁を伴う壁肥厚のために，粘液生震胞腺腫と誤診し た 1 例を除いて比較的容易であった。また，貯留震胞 の原因に膵瘦や T F P などが存在することもあった.

[結語] T F P と膆癌の鑑別には各種画像娭㚗なら びに腫漓マーカーによる総合判断が必要であり，粠腫 瘍性襄胞に成してはこれらを殹使しても，良悪性の鑑 別が困難なことが多かった。また，膆仮性衰胞，眝留 要胞では毫胞形成の原因となった他の病变の存在に注 意する必要があると考えられた。 
示-61 75歳以上高齢者勝頭部領域癌における膵 頭十二指腸切除症例の検討

鹿児島市医師会病院外科, 病理 ${ }^{*}$

田畑峯雄, 迫田晃郎, 溝内十郎, 坂元弘人, 大迫政彦, 宇都光伸, 小佐井就司, 平田晋吾, 久保昌亮, 北村 洋*, 山下兼輝*, 田中貞夫*

〔目的〕高龄者では各種荗器の予備能の低下や治療 を要する併存疾患を伴っている例が多いが手術や管理 の向上とともに高齢者膵頭十二指腸切除術の適応を考 虑する機会が增加してきている。過去 9 年間に当科で 行われた75歳以上の高齢者膵頭部領域癌における膵頭 十二指腸切除例の臨床上の特徴について検討した。

〔対象と方法〕1984年6月から1993年9月迄に経験した 膵頭十二指腸切除例は212例（悪性194例, 良性18例） で、そのうち75歳以上の高齢者は21例（悪性20例，良 性 1 例）であった。悪性疾患20例の内訳は下部胆管癌 11例、乳頭部癌 5 例、膵頭部癌4例で男女比は7:13で最 高年齢は84歳であった。75歳以上高齢者膵頭部領域癌 20例について術前併存疾患、術前ビリルビン值、術後 合併症、予後を検討した。〔成績〕術前併存疾患は14 例 $(70 \%)$ にみられ心血管系疾患 $60 \%$ 、呼吸機能障害 $30 \%$ 、糖尿病 $20 \%$ の頻度であった。術後合併症は 10 例 （50\%）にみられ、手術死亡はなかったが、2例（10 \%) が致命的合併症で在院死亡となった。膵空腸吻合 部の艂合不全を 5 例 (major leakage1例, minor leak age4例) に認めmajor leakageの1例は stageIVで術後 70日目に敗血症にて死亡した。minor leakageの4例は 造影で確認されない程度でいずれも2ヶ月以内に治癒 退院できた。MR S Aによる腸炎とIVHカテーテル 感染がそれぞれ1例みられたが抗生剂投与で短期治癒 した。術後精神障害が2例にみられたが一過性であっ た。術後肝不全で96日目に死亡した1例は减黄期間が 長期に及んだstageIVの膵頭部癌であった。入院時ビ リルビン值 $5 \mathrm{mg} / \mathrm{d} \ell$ 以下 9 例で、 $5 \sim 10 \mathrm{mg} / \mathrm{d} \ell$ 4例中 4 例、 10 $\mathrm{mg} / \mathrm{d}$ 以上7例中5例に減黄処置を行った。術前ビリル ビン值は $5 \mathrm{mg} / \mathrm{d} \ell$ 以下 14 例、 $5 \sim 10 \mathrm{mg} / \mathrm{d} \ell$ 例、 $10 \mathrm{mg} / \mathrm{d} \ell$ 以上5例であった。術後合併症と術前ビリルビン值と の相関は認めなかった。在院死亡を除く 18 例の $50 \%$ 生 存期間、 1 年生存率、3年生存率は 27.4 个月、 $61 \% 、 44$ \%であった。膵頭部癌はいずれも stage III で2年以内に 癌死した。胆管癌はstage I $: 2$ 例、II $: 1$ 例、III $: 6$ 例、 IV $: 2$ 例、乳頭部癌は $\mathrm{I}: 2$ 例、II $: 2$ 例、III $: 1$ 例で 3 年以 上生存例も認めた。胆管癌で7ケ月、嗒頭部癌で47ケ 月の他病死を認めた。〔まとめ〕高秢者では術前併存 疾患が多かったが、術前検查の正確な評価、適切な術 中、術後管理により膵頭十二指腸切除術は比較的安全 に行えると考えられた。進行膵頭部癌では長期生存は 期待できないが、胆管癌、乳頭部癌は積極的な外科的 切除をめざすべきと思われた。
示-62高齢者に対する膵頭十二指腸切除の検討 昭和大学藤が丘病院外科

木村一雄 仲吉昭夫 長崎秀彰 金城喜裁 楠本盛一 生田目公夫 熊田整

(目的) 70歳以上の膵頭十二指腸切除術 (P D) 症例 について、安全性及び予後を検討し、高齡者における PDの問題点と意義を検討した。（対象と方法）対象 は膵頭部癌24例、乳頭部癌14例、胆管癌13例、胃癌2 例、十二指腸癌1例、胆䨢癌1例の計55例で、A群: 69 歳以下（35例 平均年齢57.6歳）、B群: 70歳以上

（20例平均年龄74.8歲）の2群に分けた。検討項目 は 1 . 術前併存疾患の保有率 2 . 術中出血量、 手術時間、郭清程度 3 . 術後合併症 4 . 術後の回 復状況である。(結果) 術前併存疾患はA 群 : 糖尿病 5例、心疾患4例、貧血2例、 $B$ 群 : 糖尿病4例、肝機 能障害3例、心疾患2例、呼吸障害2例で、それぞれの 保有率はA群 $34.3 \%$ 、B群 $55 \%$ \%であった。平均術中出 血量はA群 $1690 \mathrm{ml} 、 B$ 群 $1338 \mathrm{ml}$ 、平均手術時間はA群 10.6時間、B群9.2時間でそれぞれ有意差は認められ なかった。また、B群では郭清程度はR0:3例、R1： 11例、R2:4例、R3:2例であり、高齢者の多くは R1の郭清が施行され、A群におけるものと同傾向であっ た。B群の術後合併症は膵消化管䋖合不全3例、胆管 空腸䋖合不全2例、胃空腸吻合部狭窄2例、腹腔内出血 2例、肝機能障害2例、敗血症1例、無気肺1例で消化 管吻合に起因するものが多かった。B群の術後合併症 発症者（11名）と無合併症者（9名）の術中出血量、 手術時間、術前のアルブミン值、総ビリルビン值を比 較すると術中出血量は $1491 \mathrm{ml} 、 1127 \mathrm{ml}$ 、手術時間は 8.9時間、9.1時間、術前のアルブミン值は $3.7 \mathrm{mg} / \mathrm{dl}$ 、 $3.8 \mathrm{mg} / \mathrm{dl} 、$ 総ビリルビン值は $1.6 \mathrm{mg} / \mathrm{dl} 、 1.1 \mathrm{mg} / \mathrm{dl}$ で、 術後合併症発症者で出血量、総ビリルビン值が若干の 高值を呈したが有意差はなかった。また、入院死亡例 はA群は胆管空腸䋖合不全に起因する1例のみであっ たが、B群は腹腔内出血、胆管空腸䋖合不全、敗血症 に起因する計3例に認められた。栄養状態の指標值と して術前、術後の総タンパク、アルブミンの推移を検 討すると、両群間に著名な変動は見られなかった。術 後の累積生存率、Performance status（PS）を比べ ると累積生存率は両群間に有意差は見られず、また、 B群では著名なPSの低下は確認されなかった。（結 語）1）高齢者は術前の併存疾患の保有率が高く、術 後合併症発生要因としては手術手技よりはむしろ術前 併存疾患が挙げられ、その術前のコントロールが重要 であると思われた。2）年令そのものが膵頭十二指腸 切除術の実施をためらう因子とはならないと思われ、 高齢者の術後栄春状態も比較的良好で年令相応の quality of life が得られる。 


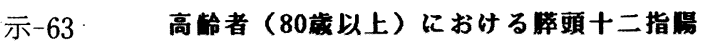
切除衙の娭討

富山県立中央病院外科, 同医床病理科・ 前田基一, 小西孝司, 福島 亘, 高田理, 長田拓哉, 二上文夫, 山本精一, 津川浩一郎, 数下和久,

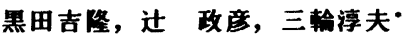

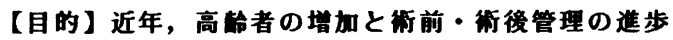
に伴い，高跲者に対しても糟的に手術が行われるよ

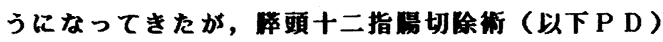
は最も唚夏の大きな街式の一つであり，鹤合不全をは じぬをす街後合併症を併発すると，時には致命的と なることも少なくない。そこで，80或以上の高峆者 $P$

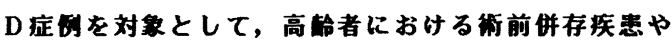
街後合併症などについて検討した。

【対象】1980年から1993年6月までに当科でPDを施行 した症例は225列であった。このうち80歳以上の症例は 19例（以下C群）であり，59葴以下61例（以下A群）, 60歳以上79歳以下 145 例（以下 $B$ 群）と比较検討した。

【成辕】原疾患別では各群ともに应頭部領域癌の占め

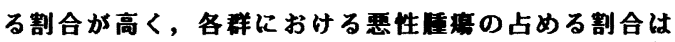
A 群が83.6\%，B群が88.3\%，C群が89.5\%と差はな かった。術前合併症の診断は, 心血管系疾患（高血压， 虚血性心疾患の敢往，心電图異常），呼吸器系疾恶

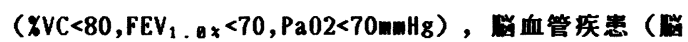

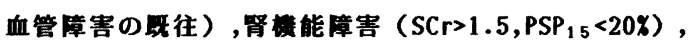
棺尿病などの有䂏より判定を行った。その結果, 街前 合併症の保有事山，B群61.4\%，C群73.7\%でA群の 29.5\%よりも有意に高かった。C群ではとくに心血管 系疾患 (47.4\%)，呼吸器系疾苇 (36.8\%) の合併か 高事であった。P Dに加え瞵接器の合併切除を施行 した症例は，A群が42.6\%，B群が35.2\%であり，C 群は5.3\%と低害であった。C群の再建法では，PD-III Aが10例（52.6\%）と最も多かった。平均手街時间は， A 群 424 \pm 120 in, B 群 $395 \pm 114 m$ in, C 群 $284 \pm 68 m$ in でありC群で短く, 術中の平均出血量は A 群 $1885 \pm$

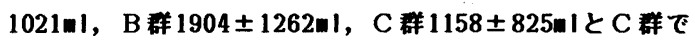
少量であった。術後合併症の併存事は，C群で57.9\% と $\mathrm{A}$ 群の $24.6 \%$ ，B群の $40.7 \% に$ 比して有意に高事で あった。在院死亡事でもC群で $31.6 \%$ と， $\mathrm{A}$ 群の4.9\%， B 群の20.7\%に比して高事であった。しかしC群にお いて前期7年同（7列）と後期7年同（12例）とで比较す ると, 手術時间, 衍中出血量ともに後期の方が淢少し, 街後合併症併存事，在院死亡事は前期が85.7\%，57.1 \%であったが，後期ではれぞれ41.7\%，16.7\%と著 しい改善が钢められた。

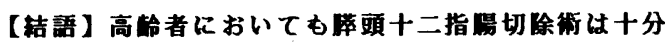
龍行可能な街式であると考えられたが，過大な手術侵 要を避けること，街前娭査成耫を十分に把握すること， 術後合併症に留意することが大切である。
示- 64 膦頭十二指晹切除衙に打ける滕空渴伆
合の工夫

北里大学外科

吉田宗紀、柿田章、高橋媇、古田一德

泉家久直、大宮東生、比企能樹

最近の手術手技と術後管理の向上に伴い、滕頭 十二指腸切除後の合併症の発生率は少なくなって きた。しかし、いったん合併症が起これば重筍と なることもあり、特に滕空晹畅合の䋖合不全、滕 波漏はしばしば致命的となるため確実で安全な物 合が望まれる。我々はより確実な物合をめさして 粗空晹物合法をエ夫し、良好な成縝をあげている のでその街式を紹介する。

[滕頭十二指晹切除街]再建法は主にPD－IIを 行5。勝の切離に続いてまず滕管にその直径とほ ぼ同じ太さの節付き滕管チューブ(住友ベークラ イト社製)を㨂入し、搭管とチューブを3-0 絧糸で しっかり結禁固定する。小腸は後結晹性に挙上す る。滕空晹畅合は端側伆合とする。

[滕空晹伆合] a ) 滕断端処理：マットレス䋖合 による閉鎖はせず、止血のみを行う。 b ) 脑管 空晹粘膜伆合：滕管チューブを挙上空腸の僛壁に 剌入するが、この時、滕管と空渴粘膜を4-0の吸 収系で 4 針程度䋖合固定する。c) 滕空晹伆合: まず、滕断端より約 $1 \mathrm{~cm}$ 離れた部位で3-0ナイロ ン系を膵前壁から後壁人而通させる。その糸針を 空腸壁の 2 ケ所（滕断端前緑と後緑が空晹壁に繾 着される部位) にそれぞれ策膜筋同のレベルで通 す。この糸を結禁すると空晹と粗は密着䋖合され る。この結热繾合を5〜6回行うと膵断端は完全に 空渴壁で閉鎖されることになる。

[考案] 安全な滕空腸吻合の条件は、1）完全な

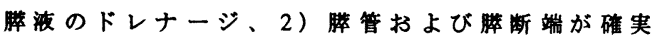
に空晹に密着していること、3) 滕断端の血流が 保たれていることと、考えられる。

滕断端と空渴の固定について我々は、滕を员通 した糸針で空渴を寄せ、滕断端を空腸壁で密着閉 鎖することを考案した。不完全な滕断端閉鎖は微 小膵管からの膆液漏出をむたらし、䋖合不全へ進 むことが照念される。従来はこれを予防するため

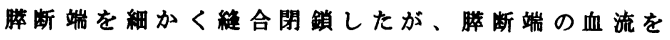

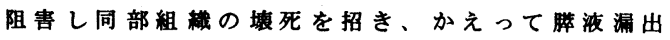
をむたらした可能性がある。我々が考案した方法 では勝断端は完全に閉鎖され、結節䋖合も数回で 済むため、従来と比べ膵断端の血流は保たれると 考えられる。酸床的にも、連続 50 症例に合併症は 全くなく、本赫式は简便かつ安全な街式と考えら れた。手術手技む简便であり、極めて有用な郝 式である。 
示-65当院における膡頭十二指腸切除 79例の検討 特に術後合併症からみた再建術式、断端腈管処置の比 較

\section{三井記念病院消化器外科}

浜田哲郎、菊一雅弘、平田泰、坂本昌義、

久保㻟自、丸山堆二、

勝頭十二指腸切除（以下P D）は、断端滕腸管吻合 を伴うため比較的合併症の多い術式である。当院にて 1975 年 2 月より1993年 10 月までの18年間にP D 79例施行 した。術後合併症は 48 例 $60.8 \%$ に発生し、術死（術後 30 日以内の死亡） 8 例 $10.1 \%$ 、在院死7例 $9.9 \%$ あった。 今回、術後合併症がないもの 31 例、術後合併症をきた したもの 48例、そのうち死亡したもの15例の3者間に、 術前総ビリルビン値、再建術式（膵小腸吻合・勝胃吻合）、

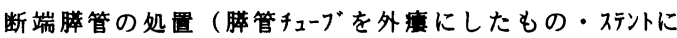
したもの）、術中出血量、手術時間、入院期間を比較 し、更に合併症について検討を加えたので報告する。 症例は男性 53 例、女性 26 例であった。対象疾患は、 要性疾患で膡癌 24 例、胆道癌 23 例、Vater乳頭部癌 17 例、 十二指腸疝 7 例、胃癌 1 例、十二指腸平滑筋肉腫 1 例、十 二指腸か几チノ忆 1 例、胆衰癌0例であり、良性疾患で胆道 良性腫瘦2例、慢性滕炎3例であった。

再建術式と断端膵管の処置は、Whipple法（変法含む） で、勝管チーブを外㾴にしたもの1例、ステントとして内痊に したもの6例であった。またChild法（変法含む）で、 膆管チーブを外㿉にしたもの23例、ステントとして内度にし たもの6例であった。次にCattell法（変法含む）で、 膵管チーブを外瘦にしたもの3例、スデトとして内㾴にした もの2例であった。膡胃吻合したもので、膡管チーブを外 㾴にしたもの6例、ステントして内度にしたもの 20 例、膵 管チーブ使用しないもの2例であった。他、膵断端閉鎖 8 例、腈全摘2例あった。

以上の術式を総合してみると膵空腸吻合 41 例で合併 症は 23 例 $56.1 \%$ （うち死亡 11 例 $26.8 \%$ ）、腈胃吻合 26 例で合併症 14 例 $53.8 \%$ （うち死亡4例 $15.4 \%$ ）であった。 また膡管チューブを外瘦にしたものが33例で合併症は17例 $51.5 \%$ （うち死亡7例 $21.2 \%$ ）、ステントにしたもの34例で 合併症 20 例 $58.8 \%$ （うち死亡7例 $20.6 \%$ ）あった。

合併症の内訳は滕吻合部䋖合不全major 16例、minor 18 例、腹胚内出血 14 例、消化管狭窄 6 例、消化管䋃合不 全 5 例、創感染 8 例、胆道感染 3 例、胸水 2 例、肺炎 1 例、 肝炎 1 例、精神不稳 1 例などがみられ、膵腸管吻合部縫 合不全による腹腔内出血が主な死亡原因であった。

結果は術前総ビリルビン値、断端䐗管の処膡（勝管チュー ブを外窘にしたもの・ステントしたもの）、術中出血量、 手術時間、に3者間の有為な差は認められなかった。再 建術式で膵空腸吻合と膡胃吻合においてその死亡率に それぞれ $26.8 \%$ 、15.4\%と後者に死亡率が低い傾向が みられた。
示-66 全胃幽門輪温存䐙頭十二指腸切除術、十 二指腸温存膵頭切除術後の残存粹線維化程度別の消化 管ホルモン分泌能について

\section{藤田保健衛生大学消化器外科第 2 科}

早川真人, 宮川秀一, 三浦 者

[目的］全胃幽門輪温存膵頭十二指腸切除術 (PPPD)や、 良性例に対する術式としての十二指腸温存膡頭切除術 (DPHP)においては消化管ホルモン分泌能細胞は比較的 温存されている。これまでに我々は膵頭切除後の消化 管ホルモン分泌能を比較しPPPD法、DPHP法の有用性を 報告してきた。今回、我々は、残存脺の線維化に着目 し、これが術後の消化管ホルモン分泌能にどのように 影笠を与えるかを明らかにするために、PPPD、DPHP術 後に食事負荷法による消化管ホルモン分泌能を膵線維 化程度別に比較検討したので報告する。

[対象と方法] 対象は当教室で経験したPPPD法36例（ 内訳はBill roth I 式腈胃吻合例 26 例、膵空腸吻合7例、 Billroth II 式膵胃吻合 1 例、膆空腸吻合 2例）とDPHP法 6例であった。方法は術後、普通食摄取可能時期に糖質 $13 \mathrm{~g} 、$ 脂質 $10 \mathrm{~g} 、$ タンパク質 $20 \mathrm{~g}$ の試験食を投与し、静脈 血中のセクレチン値、ガストリン値を経時的に測定し、 負荷後 120 分間の分泌增加累積和を求め、これを粠線維 化程度別に比較検討した。粹の線維化の程度は切除膆 の組䇅学的所見による線維化の絶対量からgrade分類し た。Grade 0はほほ正常範囲の所見であり膵実質に占め る線維化率が5\%未淽のもの。Grade 1は軽度線維化の 所見で占拠率10\%未満のもの。Grade 2は明らかな線維 化所見のみられるもので $30 \%$ 未満のもの。Grade 3は占 拠率 $30 \%$ 以上のものに分けて、grade 0を正常群、 grade 1を軽度線維化群、grade 2,3を高度線維化群に 分けた。

[結果］1)PPPD法とDPHP法の比較：セクレチン分泌能 は試験食負荷後60分値においてPPPD法が有意に高値を 示した以外に両者に有意差を認めなかった。ガストリ ン分泌能は両者間に有意な差を認めなかった。2)PPPD 法における膡線維化程度別の比較：セクレチン分泌能 に三者間に有意差を認めなかった。ガストリン分泌能 に関しては、正常群、軽度線維化群は高度線維化群に 比して良好な分泌能を示し、有意差を認めた。3)DPHP 法における膡線維化程度別の比較：セクレチン分泌能 は三者間に大きな変化を認めず、ガストリン分泌能は 正常群において良好な分泌能を示す傾向を認めた。

[結語］PPPD法とDPHP法の比較ではセクレチン、ガス トリン分泌能に有意差を認めなかったが、症例数がま だ少ないこともあり今後の検討が必要である。粹線維 化程度別にみるとセクレチン分泌能に影喑を受けない がガストリン分泌能は線維化高度なものほど低下して いた。これは、胃酸に対する膵液の中和能の低下を防 御する自己調節機能が働いていることが示唆された。 
示-67 ${ }^{13} \mathrm{C}-\mathrm{Trioctanoin}$ breath testからみた全 胃幽門輪温存膵頭十二指腸切除後の残存膵線維化程度 別の消化吸収能

藤田保健衛生大学消化器外科第2科 宮川秀一, 早川真人, 堀口明彦, 水野謙司, 石原慎, 三浦 翻

[目的]近年、quality of lifeを考虑した術式として 全胃幽門輪温存膡頭十二指腸切除術 (以下PPPD)が行わ れるようになってきた。これまでに我々は ${ }^{13} \mathrm{C}-\mathrm{Tr}$ ioctanoin breath testを用いた術後脂肪消化吸収試験 からみたPPPD法の有用性を報告してきたが、PPPD法施 行症例のなかにも消化吸収能の不良例が存在した。そ こで残存膵の線維化に着目し、これが術後の消化吸収 能にどのように影響を与えるかを明らかにするために、 PPPD術後に ${ }^{13} \mathrm{C}-\mathrm{Tr}$ ioctanoin breath testによる消化吸 収能を膵線維化程度別に比較検討した。また、腹沿神 経叢郭清を伴う払大郭清例についても同様に比較検討 し、若干の知見を得たので報告する。

[対象と方法] 対象は当教室で経験したPPPD 36例で、 そのうち払大郭清例は24例であった。方法は術後、普 通食摄取可能時期に ${ }^{13} \mathrm{C}-\mathrm{Tr}$ i octanoinを経口的に投与し $(6.5 \mathrm{mg} / \mathrm{kg})$ 呼気中の ${ }^{13} \mathrm{CO}_{2}$ を測定し、吸収率を求めて 吸収曲線を作成し、peak値、peak時間、積分値を求め、 これらを膵の線維化程度別に比較検討した。膵の線維 化の程度は切除膵の組織学的所見による線維化の絶対 量からgrade分類した。Grade 0はほぼ正常範囲の所見 であり膵実質に占める線維化率が $5 \%$ 未満のもの。 Grade 1は軽度線維化の所見で占拠率10\%未満のもの。 Grade 2は明らかな線維化所見のみられるもので $30 \%$ 末 満のもの。Grade 3は占拠率30\%以上のものに分けて、 grade 0を正常群、grade 1を軽度線維化群、grade 2, 3 を高度線維化群に分けた。

[結果] 1)膵線維化程度別の比較検討：Peak値におい て正常群、軽度線維化群は高度線維化群に比して高値 を示し、有意差を認めた。Peak時間に有意差を認めな かった。積分値において正常群、軽度線維化群は高度 線維化群に比して高値を示し、有意差を認めた。

2)拡大郭清例の膵線維化程度別の比較検討 : 三者間に 有意な変化を認めなかったが高度線維化群は吸収能は 低値であった。

[考察] PPPD法施行症例において、 ${ }^{13} \mathrm{C}-\mathrm{Tr}$ ioctanoin breath testによる術後消化吸収能は残存膵の線維化の 程度によって障害されることが示唆された。
示-68 膵頭十二指腸切除術における膵胃吻合 B illroth I 法再建法の評価

\section{金沢医科大学一般消化器外科}

斎藤人志, 瀬戸啓太郎, 谷 卓, 秋山高儀, 桐山正人 冨田冨士夫, 小坂健夫, 喜多一郎, 高島茂樹

【目的】膵頭十二指腸切除術における再建法として, 種々の術式が採択されているが, 最近, 私どもは膵頭 十二指腸切除症例に対し膵胃吻合Billroth I法再建法 ( 以下，膵胃吻合法）を試みたので，その有用性につい て検討した。

【対象と方法】過去 2 年間に教室で施行した膵胃吻合法 14例を対象に検討した。対象の疾患別内訳は, 膵頭部癌 6 例, 胆管癌 3 例, 乳頭部癌 2 例, 十二指腸癌 2 例, 膵頭 部癌と肝門部癌の重複癌 1 例であった。膵胃吻合法の実 際は, 残存膵管内にステントを留置し, 胃壁内を貫通さ せ, 残胃後壁と膵前面は一層, 後面は二層に吻合し, 残 胃と空腸はBill roth I 法に従って行なった。胆管はステン 卜を留置し挙上空腸と端側一層吻合にて行った。なお, 本法に際し門脈合併切除が 2 例, 肝左葉切除が 1 例に行 われた。これら14例について, 術後縫合不全, 術後の膵 機能(PFD, $75 \mathrm{~g}$ OGTTは術後1〜3か月目に測定)につい て検討した。同時期に胃液中のアミラーゼ值を測定し， 胃内への膵液排出動態を検索した。また, ${ }^{99 \mathrm{~m}} \mathrm{~T} c-\mathrm{PMT}$ 胆道シンチグラフィーを用い肝門部および挙上空腸におけ る60分停滞率を求め, Child法 ( 5 例) の胆汁流出動態と 比較検討した。更に ${ }^{99 \mathrm{~m}} \mathrm{Tc}$-DTPA消化管シンチグラフィー により胃内停滞率と 2 時間後, 3 時間後の消化管内集積 状況を検索し，胃内容排出動態についても併せ検討した。 【結果】本再建法の術後合併症として縫合不全は 1 例 もなかった。PFD testは14例中2例(14.3\%)が術前值 より低値を示した他はいずれも術前值と同様の值を示 した。75 gOGTTは, 基礎疾患に糖尿病を有した 4 例を 除き，他の全例に耐糖能の低下はみられなかった。胃 液中アミラーゼ值はP分画が36〜3880 IU / L (平均 1850 $\mathrm{IU} / \mathrm{L}$ )を示し, 膵液の胃内流出を確認した。胆道シン チグラフィーでは肝門部の60分停滞率にChild法と差はみ なかったが, 挙上空腸の60分停滞率で膵胃吻合法が

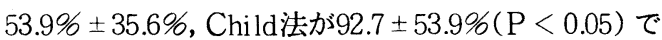
Child法に比し胆汁うっ帯は軽度であった。消化管シン チグラフィーを施行した 8 例では経口摄取60分後の胃停 滞率は50〜60\%を示し，また 3 時間後の胃内集積像は全 例にみられず，良好な胃内容排出を示した。

【結果】本法術後に合併症として縫合不全はなく, 残 存膵機能の保持, 並びに胆汁の挙上空腸内うっ滞, お よび胃内容排出遅延むみられず，本再建法は膵頭十二 指腸切除術における再建術式として有用であるととが示 唆された。 
示-69 胆膵領域癌における全胃幽門輪温存膵頭十 二指腸切除術症例の検討

国立福山病院外科

高倉範尚, 柏原瑩爾, 山本浩史, 村上仡

高橋健治, 小林直哉, 大海研二郎, 池田雅彦

【はじめに】㬸器機能保持の立場から近年、全胃幽門輪 温存膵頭十二指腸切除術 (以下、PPPD) が胆膵領域癌 に対して適用されてきているが、当科でも1989年以降、 胆膵領域癌の一部に本術式を行ってきた。今回はこれ らの手術成績を検討し、胆膵領域癌に対する PPPDの 意義、適応について考察したので報告する。

【対象・基本術式】乳頭部癌 12 例（stage I 4 例、II 6 例、III 1 例、IV 1 例)、膵癌 8 例 (stage II 2 例、III 4 例、 IV 2 例)、胆管癌 2 例（stage II 2 例）、胆素癌 $\mathrm{I}$ 例（stage

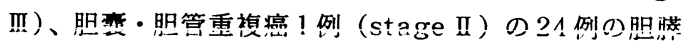
領域癌に対しPPPDを行った。当科における基本再建 術式は膵胃吻合を用いた B - I 方式であったが、1993 年以後は今永法に準じた再建を行っている。24例の再 建術式は膵胃吻合 B - I 方式 16 例 (膵嵌入法 7 例、膵 管嵌入法 1 例、膵管粘膜吻合 8 例)、今永法 8 例（膵管 嵌入法 1 例、膵管粘膜吻合 7 例）であり、また門脈合併 切除を 5 例に行った。

【結果】組織学的治癒切除は乳頭部癌 12 例中 10 例、脺 癌 8 例中 3 例、胆管癌・胆曾癌 4 例中 3 例に得られた。 非治癒切除因子はn $>$ R、hw、pw、ewがそれぞれ 2 例であったが、PPPD術式による非治癒切除症例はなか った。術後合併症は 6 例 $(25 \%)$ に認められた。合併 症の内訳は膵胃吻合繾合不全 4 例、胆管空腸吻合縫合不 全 1 例、イレウス 1 例、腹壁創感染 2 例であったが、全 例保存的治療で軽快した。なお膵胃吻合繾合不全症例 はすへて胃全層切開・膵嵌入法症例であり、膵管嵌入 法、膵管粘膜吻合症例には認めていない。術後の胃内 容うっ滞は多くの症例で認められ、2调間は500〜 1000 $\mathrm{m} \ell$ の排液を認めるが、経口摂取開始以後の, 食事揸取量 は十分で、術後の体重减少も5\%内外で推移しだ。予後 であるが治癒切除 16 例中 3 例、非治癒切除 8 例中 $i$ 例 が死亡したが、他は最長 3 年 9 力月生存中である。治癒 切除例中 4 例に再発が認められ、部位は肝 1 例、脳 1 例、 肺・大動脈周囲リンパ節・Virchow リンパ節 1 例、肝・ 大動脈周囲リンパ節 1 例であり、PPPD 術式、郭清範囲 には関連ないものと考えられた。

【結語】PPPDを行った胆膵領域癌 24 例について検討 を加えた。組織学的非治瘾切除は8例であったが、PPPD 術式に関連したものでなく、また治痣切除例中の再発 例についても同様であり、さらに術後のQOL も良好に 保たれることから、今後も胆膵領域癌に対して積極的 にPPPDを適用していく考えである。
示 -70

\section{十二指腸乳頭機能の臨床病理学的評価}

昭和大学外科 ${ }^{1 ） 、 \text { 同第一病理 }}{ }^{2)}$

伊達 淳、新井一成、石井 博、丸岡義史、富永幸 治、草野満夫 ${ }^{2}$ 、副島和彦、神田実喜男 ${ }^{2)}$

良性胆道系疾患、特に総胆管結石症における術前乳 頭機能評価は、付加手術の適応を決める上で重要であ る。今回、内視鏡的逆行性膵胆管造影（以下E R C P) 時の乳頭肉眼形態、胆管造影像および胆道内圧所見か ら乳頭機能評価を行い、また剖検例の組織学的検索を 含め検討した。

対象及び方法 : 過去10年間に教室で経験したE R C P 症例のうち膵胆管造影上異常を認めない65例（以下A 群）、総胆管結石症例163 例中評価可能な下部胆管造 影の得られた87例 (以下B群) を対象とした。A群及 び B 群の十二指腸鏡所見上の乳頭形態を乳頭像 (半球、 隋円、扁平) 開口部形態（絨毛、顆粒、裂口、縦口） 口側隆起（なし、軽度、著明）の3 項目につき比較検 討し、造影所見ではB群のnarrow distal segment

（ND S）の形態を(1)ロート型 : 滑らかな円錐を呈す るもの(2)狭窄型 : 針金状の狭窄部位を認めるもの(3) 柱型 : 㹨窄部位が短く胆管が円柱状を呈するものの3 型に分類し、各々の経時的律動運動 $(+t,+,-)$ 及び乳 頭形態を比較した。また組織学的には剖検例より得ら れた正常乳頭部34例、総胆管結石症例4 例を比較した。 結果 : 乳頭像ではA 群 B 群との間に差は認めなかった。 開口部形態では顆粒型がA群 $83.1 \%$ と最も多かったの に対し、B群では裂口 $24.1 \%$ 、縦口 $17.2 \%$ 割合 が高かった。口側隆起はA群では軽度 $63.1 \%$ \%か多か ったが、B群では著明 $71.3 \%$ と両者間に有意な差を 認めた。

ND S の形態と経時的律動運動を比較すると(1)ロート 型では $(+t): 61.7 \%$ (t):27.7\%,(-): 10.6\%に対し、 (2)狭窄型では $(t): 36.8 \% 、(t): 26.3 \% 、(-): 36.8 \%$ 、 (3)柱型では $(+t): 5 \% 、(t): 15 \% 、(-): 80 \%$ 乳頭部形態と N D S の関係は口側隆起に差は認めなか ったが、開口部形態では(1)ロート型では顆粒 $72.3 \%$ 、 裂口 $23.4 \%$ 、縦口4.3\%に対し(2)狭窄型では各々 42.1 \%、26.3\%、31.6\%、また(3円柱型では40\%、30\%、 $30 \%$ と狭窄型、円柱型において縦口の頻度が高かった。 組織学的には絵胆管結石症例で胆管下部括約筋の線維 増生、筋肥大を認め、形態に影響を及ぼす因子と思わ れた。 E R C P 時の胆道内圧測定においても症例数は 少ないものの同様の傾向を認めた。

結語 : 従来乳頭機能不全に多いとされてきた狭窄型、 円柱型を呈するものはロート型と比較してND S の律 動運動が不良で、十二指腸鏡所見上、開口部形態は縦 口のものが多く、付加手術を考虑する上で、胆道内圧 と共に重要な所見と考えられた。 
示-71 十二指腸傍乳頭款室症例の乳頭部機能の 評価 一 術中胆道内圧測定法による検討 —

大阪警察病院 外科, 大阪厚生年金病院 外科* 宮崎 知, 坂本嗣郎 ${ }^{*}$, 山崎芳郎*, 中尾量保,

桑田圭司*

【はじめに】十二指腸傍乳頭憩室の胆道疾患における 臨床的意義に関しては多くの報告があり, 病態の解明 には乳頭部機能評価が重要であり，その目的に胆道内 圧測定が行われている。しかし, 対象の選択や測定方 法が異なり一定の見解は得られていない。今回我々 は，胆道疾患症例を憩室及び胆管拡張の有無により 3 群に分類し, 乳頭部機能を十二指腸内圧負荷前後の胆 道内圧所見にて比較検討した。

【対象】開腹術を施行した胆囊結石31例，胆囊ポリー プ 2 例，総胆管結石 2 例。レンメル症候膡 6 例の計 41 例を対象とした。そのうち，傍乳頭憩室を有さず総胆 管径が $10 \mathrm{~mm}$ 未満の 26 例（対照群），硨室を有し総胆管 径が $10 \mathrm{~mm}$ 未満の 6 例（非拡張群），硨室を有し総胆管 径か $10 \mathrm{~mm}$ 以上の 9 例（拡張群）の 3 群に分類した。

【研究方法】開腹下胆摘後, 胆囊管断端より胆道内圧 測定用チューブを総胆管, 乳頭部に㨂入し, 十二指腸 内圧負荷 $(300 \mathrm{~mm} H 20)$ 前後の乳頭部括約筋の収縮頻度, 基礎圧, 胆道抵抗値を測定し, 同時に術中胆道造影に おける十二指腸への造影剤の流出状態を観察した。

【結果】上段;十二指腸内圧負荷前, 下段; 内圧負荷時

\begin{tabular}{|c|c|c|c|}
\hline & 対照群 & 非拡張群 & 拡張群 \\
\hline 鄎室径( mm) & - & $10.2 \pm 2.2$ & $27.8 \pm 10.3^{\#}$ \\
\hline $\begin{array}{l}\text { 乳頭収縮波 } \\
\text { 出現率(\%) }\end{array}$ & $\begin{array}{l}25 / 26(96.2 \%) \\
13 / 22(59.1 \%) \\
\end{array}$ & $\left\{\begin{array}{l}5 / 6(83.3 \%) \\
4 / 6(66.7 \%) \\
\end{array}\right.$ & $\left\{\begin{array}{l}7 / 9(77.8 \%) \\
1 / 9(11.1 \%)\end{array}\right.$ \\
\hline $\begin{array}{c}\text { 乳頭部基礎圧 } \\
(\mathrm{mmH} 20)\end{array}$ & $\begin{array}{l}266 \pm 57 \\
454 \pm 89 \\
\end{array}$ & $\begin{array}{l}292 \pm 64 \\
504 \pm 118\end{array}$ & $\begin{array}{l}206 \pm 79^{* \#} \\
708 \pm 91^{* *}\end{array}$ \\
\hline 胆道抵抗值 & $\begin{array}{l}0.42 \pm 0.29 \\
1.03 \pm 0.22\end{array}$ & $\begin{array}{l}0.36 \pm 0.19 \\
1.02 \pm 0.21\end{array}$ & $\begin{array}{l}0.22 \pm 0.20^{*} \\
1.22 \pm 0.14^{*}\end{array}$ \\
\hline
\end{tabular}

十二指腸への $26 / 26(100 \%) \quad 6 / 6(100 \%) \quad 9 / 9(100 \%)$ 造影剤流出率 $25 / 26(96.2 \%) \quad 5 / 6(83.3 \%) \quad 2 / 9(22.2 \%)$

* $=p<0.05$ vs 対照群, * $=p<0.05$ vs 非拡張群

【まとめ】1)拡張群の鄎室径は非拡張群に比し有意に 大であった。2)十二指腸内圧負荷前では拡張群の乳頭 部基礎圧, 胆道抵抗值は他の 2 群に比し有意に低値を 示した。3)十二指腸内圧負荷時には拡張群の乳頭部基 礎圧, 胆道抵抗值は他の 2 群に比し高値を示し, 乳頭 収縮波出現率および胆道造影における十二指腸への造 影剤の流出率は低(傾向を示した。4)対照群と非昖張 群の胆道内圧所見には十二指腸内圧負荷前後ともに差 を認めなかった。

【結語】胆管拡張の無い喤室症例の乳頭部機能は保持 されているが, 胆管拡張を来した惒室症例では乳頭部 機能は不全状態にある事が示唆された。
示-72胆・粗管奇形に対する胆道再建 : 長期遠 隔成樍からみた問題点

鹿児島大学小児外科, 都城市国吉医院*

有馬榮徳, 田原博幸，国吉 真*

[目的]胆・腪管奇形は良性のものが多いが, 费胆管異 常では癌化する例もあり，異常の見逃しや再建術の不 傮により合併症再発や悪性化例も見られるので胆道再 建にあたっては留意すべき点が多い。過去34年間の自 験胆腪管奇形胆道再建術後長期筑察例を中心に診断, 手術，追跡上の問題点を検討した。

[方法]縢胆管合流異常を伴う先天性胆道拡張症 132例 同胆道無拡根12例, 合流異常を伴う胆道閉鎖 - 低形成 症, 孚児肝炎 12 例, 先天性十二指腸閉塞症, 陯状膡に 合併する胆道拡張 - 狭窄 8 例、十二指腸乳頭分離開口 2 症例等の術後 10 年以上経過例について診断, 治療, 追跡調查上の問題点について分析した。

[成樍] 1. 合流異常を合併する胆道払張症 : 较腫腸管 吻合12例は合併症で10年前後経過後再手術、全例に膆 線維化，術前有石例は結石再発が見られたが 4 例は術 後20年以上経過後も著変なし。膹胆管分流手術後手術 不的確による赛腫遗残部・脾内胆管結石再発, 肝内肝 管狭窄見逃し・無処置分流術後18年目の多発性肝内結 石再発発症各 1 例。2.合流異常を伴わない胆道払張 症 8 例には上記の術後合併症は見られず。3. 新生児 期発症胆道奇形は黄疸 - 肝硬変急速進行例多し。 4 .

5. 胆道低形成症 5 例は全例合流異常合併, 10 年以内 に死亡。6. 乳児肝炎の合流異常合併 3 例は激症肝炎

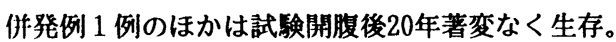

7. 新生児 - 乳児期の棆状縢 - 十二指腸閉塞性胆道狭

窄, 払张例は胆道に直接侵襲を加えることなく十二指 腸狭窄の修復手術のみで治瘜したが，17歳で発症手術 した症例は胆道再建を必要とした。

[考案] 合流異常合併例は胆管・亚炎, 瘦, 結石発生 を顧虑して早期の確定診断と術前 - 中画像診断, 消息 子による術中㬳・胆管, 合流点探索と的確な手術が重 要。衰腫内結石新生児期破裂症例 1 例も経験しており 先天性結石・喜腫も䫏慮し胎生期エコー集検が望まれ とくに術前有石例では術後長期の定期エコー検索が重 要。術後結石再発時の非手術的切石術可能な術式が術 前有石例の胆道再建術には望ましい。胆道閉鎖症の合 流異常合併例では肝門胆衰吻合は推䍃できない。胆道 低形成および肝管・肝門部肝空腸吻合術無効な胆道閉 鎖症例では早期の肝移植が必須となる。

[結論] 胆・粗管先天奇形に対する再建術式は的確な 術前・ 中画像診断, 消息子探索, さらに胎生期エコ一 集娭が重要であり，胆管炎・結石，癌化，脺炎・石発 生や術後再発も予測し, 再発時の非手術的治療可能な 術式の選択, protein plug, 胆泥・砂の洗浄除去, 的 確な再建と術後長期の定期的追跡検索が重要となる。 
示-73 胆道拡張症および生体肝移植における胆道 再建とその問題点

\section{名古屋市立大学第一外科}

音部好宏、橋本俊、清水保延、山守帽子、伊藤浩一 小林建司、中村善則、花井拓美、中村司、鈴木速也 林周作、真辺忠夫

【目的】胆道再建における問題点として、胆管晹吻合 法、再建に用いる消化管部位があげられる。また、吻 合部狭窄や胆管炎といった胆道再建に伴う合併症の評 価には長期的な释䢔钼察が必要となる。そこで胆道再 建後 10 年以上を释過した症例および胆道再建に工夫 を要した症例、生体肝移植における胆道再建の合併症 を検討するととるに胆道再建上の問題点を明らかにす ることを目的とした。

【対象および方法】56例の小児先天性胆道拡張症の内 術後10年以上経過し、来院可能でおったのは18例で、 再建術式は十二指晹吻合（D群）13例、空晹吻合 （J群）5例である。また、左右肝管を個々にdouble $\mathrm{R}-\mathrm{Y}$ 吻合とした 1 例、総肝管の十二指腸粘膜下植込み 吻合が 1 例、副肝管をR-Y 胠に追加吻合した 1 例があ る。これらの他に生体肝移植庭例 9 例を今回の検討対 象とした。いずれの症例も胆管腸吻合は吸収系の連続 繾合を用い、ステントチューブは肝移植の 4 例に用い たのみである。10年以上释過症例については画像診断 を含めて D、J 群の比較を行い、再建上の工夫を要し た 3 例および肝移植症例については合併症を含めた再 建上の問題点を検討した。

【結果】長期経過症例では D、J群とるに1例ずっ肝 内結石の発症をみ、再手術を行っているが、共に吻合 部の器質的狭窄はなく、初回手術時の胆管拡張部の残 存が関与していたと考えられた。来院時、超音波検査 上、吻合部狭窄による肝内胆管の拡張は 1 例も認めら れなかった。血液生化学的検查でる㻌血後 C 型肝炎を 発症した 1 例を除き概ね正常範囲内であった。胆计の 用内逆流による周炎（D群の 2 例）以外、再建術式に よる差異は見られなかった。特殊な再建を行った 3 例 でも術後 $1 \sim 4$ 年を経過したが、合併症の発症はみて いない。これらの結果から、生体肝移植における胆管 腸吻合はモノフィラメント吸収系を用いた連続繾合で 行っているが、肝勣脈血栓症を発症した 2 例で繾合不 全を経験した以外、ステントチューブを留置しなかっ た症例においてる吻合部狭窄はみられていない。

【結語】1.胆道拡張症において、再建術式の連いに よる合併症の差異は見られなかった。2 、胆管腸吻合 は、吸収系を用いた連緒梿合で行ってす、長期的にみ て器質的な吻合部狭窄を来すことは少ないと考えられ る。3．生体肝移植においては、肝䡃脈血流が術後胆 道系合併症の発生に大きく関与していると考えられた。
示 -74

良性胆道狭窄 39 例の検討

$$
\text { 鹿児島大学第二外科 }
$$

生駒明、田中紘弾、石部良平、吉㒹巡、

西村明大、腥方誐司、平明

【目的】良性胆道狭窄の原因、臨床像、治法法、成 績等を検討しその問題点を明らかにし、最近経検した 症例を呈示する。【対象】最近 15年間に教室で経糇し た良性疾患に起因する胆道狭窄症例から先天性胆道拡 張症、原発性肝内結石症に付随する胆道狭䆣症例を除 いた39例を対象とした。【結果】狭窄をきたした原因 疾患は乳頭部狭窄が 11 例、種々の腹部手術後が10例、 Mirizzi 症侯群が 8 例、慢性勝炎が 5 例、胆素炎また は胆管炎が 3 例、原発性硬化性胆管炎か 1 例、TAE 後 が1例であった。種々の腹部手術に起因した10例の内 訳は盟摘の 8 年から 24 年後に三管合流部付近に狭窄を 来たしたものが 4 例、胆摘術中に総胆管を結紮したも のが 1 例、同じく総胆管を損偒したものが 1 例、販頭 括䄪筋形成術の10年後に乳頭部狭窄を起こしたものか 1 例、その他 3 例（後述）であった。臨床症状では上 腹部痡が $82.1 \%$ に、黄㾝が $30.8 \%$ に、発熱が $20.5 \%$ に 認められた。入院時検査ではT.Bil $4.64 \pm 1.46 \mathrm{mg} / \mathrm{d} 1$ (

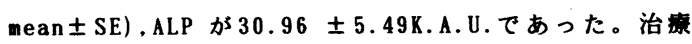
方法は、医原性胆道狭窄の症例には狭窄部位と程度に よって、胆管空晹吻合術、総胆管切開および $\mathrm{T}$ チュー ブドレナージ等を使い分け、乳頭部狭窄には乳頭括的 等形成術を、慢性膵炎には胆管空晹吻合術を主に施行 した。手術成績は症状、検査成樍ともほほ正常化した ものが15例、改善したが異常が残るもの20例、胆道感 染、敗血症等合併して死亡したものが 4 例であった。 以下最近経强した症例を呈示する。【症例】症例 $1: 58$ 歳男性。肝細胞癌で肝切除後残肝再発にTAEを 3 回施 行し11ヶ月後に右肝動脈の完全閉塞および䊅肝管の高 度狭窄を起こした。症例 $2: 71$ 歳女性。置医に胃要全摘 および肝十二指晹間膜内リンバ節郭清を行い1週間後 より黄㾝が出現し 2 か月後に総胆管の完全閒塞を認め た。症例 $3: 29$ 瓷女性。腹腔鏡下胆摘時に右肝管を損湶 しドレーンからの胆汁漏か続き、2 2 月後に造影で棯 胆管の完全阙塞を認めた。症例 $4: 36$ 歳女性。肝内結石 症に対する肝後下亜区域切除後に肝切䧿面より胆汁漏 が続き、4 か月後総胆管の完全閏塞を認めた。

【まとめ】良性胆道狭窄は原因、治涚法とも多岐にわ たり、術後も異常が残る例が少なくなく術式の選択に は注意を要する。TAE、リンバ節郭清による胆管虚血や 持続性胆汁漏による慢性炎症に起因すると思われる胆 道狭窄を経唉した。今後新しい術式の開発や侵意の払 大に伴い、新しい機序の胆道狭窄がみられる可能性が あり慎重な対応か望まれる。 
示-75 胆尔損症の臨床的特徽

一当院で経験した肝内結石を伴う 1 例と本邦83 例の 集計から一

福井赤十字病院外科

広颗由紀，土居幸司，小柴贯明，佐藤史頙，田中文恵， 山本広幸, 松下利雄, 城崎应一郎, 田中猛夫

【目的】胆素久損症は比較的稀な疾急である。今回 我々は肝内結石症を合併した胆夏欠損症を経駼したの で本邦報告例の梌事と共にその臨床的特徽を症状、血

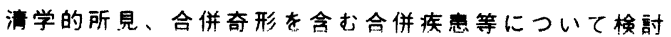
したので報告する

【対象】1927年 $\sigma$ 邦第 1 報告例から自験例のうち 現時点で検索し得た小児例を除く84例。平均年令 53 才。男性 35 例女性 44 例である

【結果】(自験例) 症例は59才男性。特に症状はな く、健康診断で胆石症疑いにて精査を勧められる。黄 瘨等認めず，既往歴、家族歴に特記すべきことなし US、CTにて慢性菱縮性胆糞炎とS3の肝内結石症の診 断、ERCPでは胆要は造影されず胆管のみがみられ、 また総胆管の拡張はあるが险影欠損はなし。手術所見 では胆真あるいは索状物はなく、総胆管に胆事管の遗 残と思わ机る小突起を認めたのみであった。胆事欠損 症と䛦断しS3の肝亜区域切除のみを施行した(集計結 果) 合計 84 例を榢討した結果、まずその症状で明らか に無症状を呈したのは3例のみで、右季助部痛等の疼 痛が 64 例 $(76 \%)$ に認められ、黄值は84例中 23 例（ $27 \%$ )にみられた。肝機能障害としての血清学的所見 では45例中 18 例 $(40 \%)$ が異常を示し残り27例（ $60 \%$ ）が正常であった：小児例を除いた 8 例が合併奇 形を示し、その内訳は右胆管分枝異常、膵管非痹合、 鉡状勒蒂欠損、副胆管、先天性低形成堅、愺胆管合流 異常、分葉肝およびM e ckel㮩室である、胆道系悪性 疾㶳では胆管癌を了例に他の悪性疾患では罱癌を了例み た。総胆管の拡張は娭索し得た 65 例中 43 例の66.2\% に、総胆管結石は63例中 19 例の30.2\%に認められ、 肝内結石は 46 例中の6例 $13 \%$ を示した

【考察】胆䨢欠損症において総胆管結石の合併が多 いことは啫家が報告しているが、今回の集計において も総胆管拡張 $66.2 \%$ 、総胆管結石 $30.2 \%$ と高率であっ た。黄瘨の出現、肝機能障害は有意に総胆管拡張およ び結石の存在と相関しておりその臨床的特徵を現して いるものであった

【結語】肝内結石症を合併した胆曹欠損症の1例を文 献的考察を加え報告した，主にその臨床的特徵に視点 をおき検討したが、2次的に生ずると思われる絰胆管 拡張がその主役を成していると考えられた
示-76 肝門部胆管合流形式と「副肝管」の用語 の妥当性に関する検討

大阪市立大学医学部第 2 外科

中村弘樹, 木下博明, 広橋一裕, 久保正二, 田中宏 塚本忠司, 久保田太輔, 村瀬順哉, 森本義彦, 金沢景繁 〔目的〕胆管系の合流形式の把握は肝胆道手術の合併 症を予防する上で重要であるが, その合流形式につい ては系統的に確立された概念は無く, とくに「副肝管」 の用語については施設間で見解や定義, 分類方法に相 連がみられる。我々は胆管系合流形式を検討する際の 視点を胆衰や胆蓄管よりも肝門部においた方が合理的 ではないかと考えた。そこで自験例の肝門部胆管合流 形式を検討し，あわせて「副肝管」の用語の妥当性に ついて考察を加えた。〔対象と方法〕当科で直接胆管 造影の行われた肝胆道疾患開腹手術 213 例を対象とし た。直接胆管造影像においてまず, 総肝管から肝内に 数えて肝管の第 1 次および第 2 次分枝の合流形式に注 目し，肝門部胆管合流形式を検討した。〔結果〕肝門 部胆管合流形式は基本的に 2 枝合流型（70\%)，3 枝合 流型 $(14 \%)$ ，後枝独立合流型（5\%）および前枝独 立合流型（11\%）の4種類に分類された。すなわち, 2 枝合流型は右前・後枝が合流して右肝管を形成し左 肝管と合流するもの，3枝合流型は右前・後枝と左肝 管が同一部位で合流するもの, 後枝独立合流型は右前 枝と左肝管が合流したのちに右後枝と合流するもの， 前枝独立合流型は右後枝と左肝管が合流したのちに右 前枝と合流するものである。なお，第 3 次分枝以降の 胆管枝が肝門部付近ないし 3 管合流部の胆管に合流す る破格がみられた場合はこれらいずれかの型の亜型と した。すなわち， 2 枝合流型の亜型が 6 例にみられ， その内訳は右肝管に第 3 次分枝の後上枝と後下枝が別 個に合流する症例, 第 4 次分枝以降の細い胆管枝が肝 門部で合流する症例, 尾状葉胆管枝が総肝管左側に合 流する症例がそれぞれ 2 例（1％）ずっであった。

〔考察〕右肝管を形成しない 2 枝合流型以外の型が30 \%に存在し，これらは手術操作にあたって留意される べきと考えられた。2 枝合流型の亚型の胆管枝は後枝 独立合流型の右後枝や前枝独立合流型の右前枝ととも に，「副肝管」とされることがある。しかし，元来 「副肝管」とは主たる胆汁排出路とは別に存在する付 随的肝管であり, 今回みられた「副肝管」とされる可 能性のある胆管枝は実はすべて肝管の第 $2,3,4 \cdots$ $\mathrm{n}$ 次分枝（ある肝領域の唯一の胆汁排出枝）の破格之 考えられた。〔結語〕「副」は付随的な意味ゆえ, 機 能的に同等な胆管枝が形態上「副肝管」とされるのは 不適当で, この場合「異所性肝管 (variant hepatic duct）」と呼称すべきであると考えられた。

〔文献〕中村弘樹, 他; 肝門部胆管合流型式の検討, 胆道 $8: 22-28,1994$. 
示-77総照管内に広く程の進展をみた合流異常を 伴う総照管应張症 $の$ 一切除例

礁水病院外科，群馬大学第 2 外科:

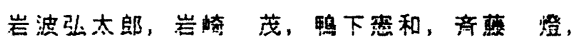
大和田進”，森下蛙雄”。

（はじめに）総胆管应镸症に愺胆管合流異裳の随伴上

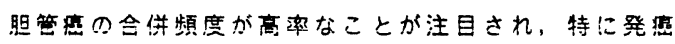

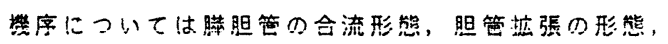
切除標本の病理組綪学的梌索など多角的な検尌が行わ れている。今回，粘膜内に広く進展した盟管密弇供 した腊盟管合流異裳を伴う総盟管应張症を経騷した で報告する。

（应例）68文，女性。昭和6 3 年 2 月頃上り上腹部 瘦あり，当院内科で精查の結果，総盟管应張症と診断 されていたが保存橑法のみで入温院綝り返していた。 平成 5 年 4 月にも同样の発作があり手術のため当科に 入院となった。家族歴に特記專項は無かった。

（入院時模查所見）血液梌查では白血球の上星态認め， GOT，GPTの上界とともに腿道系酵素の上暴も認 めた。腫湔マーカーは正掌籍囲であった。腹部超音波

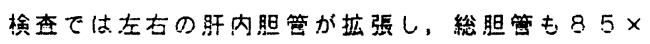

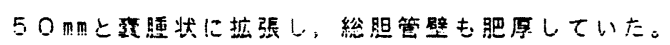

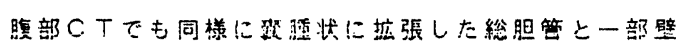
の不整隆起を認めた。ER C Pでは䀒内盟管志よず総 照管の蓄明な变腫状拡镸を認め, 旰内䀒外多発型を示 していた。旰内照に管に狭窄はなかった。膵胆管合流部 は裸赫な合流異掌を呈していた。以上上り眰胆管合流 異掌を伴う総照管垃镸症と牾断し手術を施行した。

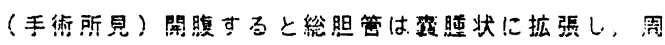
囲にやや资症があり血管に富んでいた。手術時の触誩

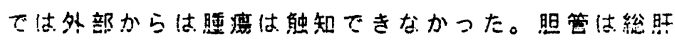

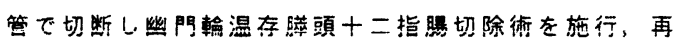

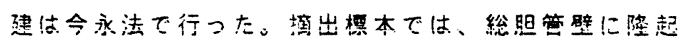

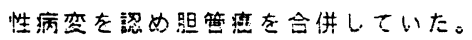

(病理肉眼及び組雬所胃) 総胆管内部に力リフラワー

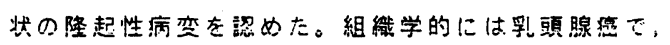

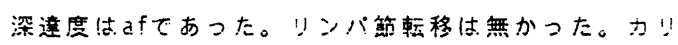

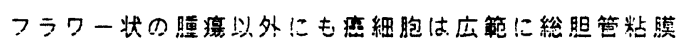

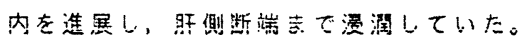

(術後経過) 術媵，照内照射をト一タル24Gy施行し、

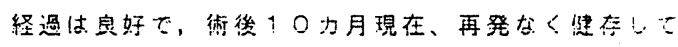
いる。

（声とめ）合流異常を珰う総盟管应镸症に盟笛癌が合 供することはよく知られている。今回，旰側断端志

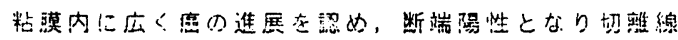
の決定が問题となった症例在経駼したので，総照管应

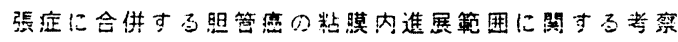
を加之埌告する。
示-78 肝左葉切除, 左尾状葉腹側部部分切除術 を行った脺管胆道合流異常合併肝内結石症の 1 例 左尾状葉部分切除の可能性について

宮城厚生協会 長町病院外科 ${ }^{1)}$,

同 坂総合病院外科 ${ }^{2)}$, 古川民主病院外科 ${ }^{3)}$

阿南陽二1), 横山成紀 ${ }^{1}$, 河野兵衛 ${ }^{1}$, 平野貞夫 ${ }^{2)}$,

大窪 豊党, 松田好郎 ${ }^{2)}$, 小熊 信 ${ }^{2)}$, 和田昌史 ${ }^{3)}$

【はじめに】肝内胆管枝の合流形態にはバリエーショ ンが多く，尾状葉胆管枝も例外ではない。左尾状葉枝 の場合，1本の枝を形成せずに左肝管に合流する例や， そのうちの 1 本が右肝管に合流する例がある。こうし た症例では, 早川らの報告 (日消外会誌 $25 ： 1835-$ 1835，1992)のように, 左尾状葉か淜复側部と背側部に 区別できることがある。今回その観点から，左尾状葉 腹側部切除を含む肝左葉切除術を行った肝内結石症例 を検討したので報告する。

【症例】57歳, 男性, 主訴: 腹痛, 発熱, 既往歴: 約 20 年前に胃潰瘍のため胃切除術を受けている。 7 年 前胆管結石症のため手術 (胆管切石術)を受けたが, 肝 内外胆管に結石が充満していたため不完全切石となっ た(いずれも他院)。現病歴：1992年8月より発熱と腹 痛をくりかえすため, 同年10月当院紹介となった。血 液検查成績: GOT $18 \mathrm{KU}, \mathrm{GPT} 13 \mathrm{KU}$, ALP 51.7 $\mathrm{KAU}, r \mathrm{GTP} 211 \mathrm{IU} / 1$, T. Bil $0.64 \mathrm{mg} / \mathrm{dl}$ で, 胆道系酵素上昇を認めた。胆管像：左肝管より経皮経 肝胆管ドレナージ (PTCD)を行った後, 経皮経肝胆道 鏡検查 (PTCS) による胆道精査を行った。左優位, 肝 内優位の両葉型, 肝内外型肝内結石症で, 肝外胆管と 左肝管は著明に拡張していた。また, 膵管胆道合流異常 を認めた。PTCS下に切石を行い，各区域胆管枝を 精密に検討したところ,左尾状葉枝には2本の枝があり， 1 本は左肝管に合流し，もう1本は右後枝に合流して いた。血管造影像：肝動脈造影では異常所見を認めず, 門脈造影では門脈左枝および左葉各区域枝に萎縮を認 めた。手術所見: 切石後も左肝管挔張があり, 膵管胆 道合流異常症を合併するため, 肝左葉切除, 尾状葉腹 側部切除および胆管切除を予定術式として, 1993年1月 27日手術を行った。上腹部に激しい瘾着を認め, 肝左 葉および胆䝔は萎縮していた。左尾状葉は腹側と背側 の間に溝を形成していた。膵内胆管から右肝管までの 胆管切除を含む予定手術を行い，右肝管と空腸を吻合 した。病理検査では悪性像は認めなかった。

【考案】左尾状葉枝の合流形態を術前に詳細に検討 し, 左尾状葉部分切除を併施することによって, 切除 胆管枝と肝切除範囲を一致させる合理的手術が可能で あった。 


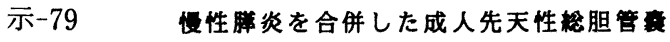 䤚の一治䮲例}

岡波総合病院外科

朝川壹松、山村国司、三宅哲也、猪木弘三 症例：56 歲、男性。

主新：腰背部痛と黄瘨。

既往歴、家族歴：特記すべきことなし。

現病歴: 数年来某医にて肝機能障害にて加療中であっ たが、全身倦急感を主訴に平成 3 年 6 月 19 日当院内科

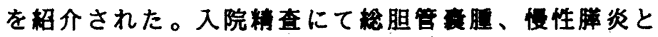
診断されたか、手術拒否にて外来通院となった。平成

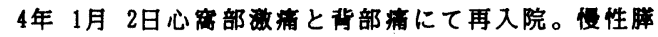

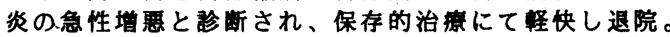
退院以後通院せず、平成 5 年 2 月 16 日、腰背部有と 黄疸のため当院内科を受彮し再々入院となった。

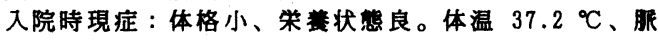
拍 $102 / \mathrm{min}$ (整) 、血压 $148 / 94 \mathrm{mmHg}$ 。眼けん結腃に 血なく、眼球結腃に軽度黄疸を認めた。心肺打䏇祄 上界常所見なく、腹部は心窝部を中心に蛙度膨隆し同 部位に一致し压瘏を認めた。

入院時臨床模查成：一般検血に異常所見なく、生化 学模㚗所見では T-Bil $3.23 \mathrm{mg} / \mathrm{dl}, \mathrm{D}-\mathrm{Bi} 12.01 \mathrm{mg} / \mathrm{d}$ 1 と黄瘨を示し、GOT $194 \mathrm{IU} / \mathrm{L}$ ，GPT $306 \mathrm{IU} / \mathrm{L}, \mathrm{LA}$ P $1375 \mathrm{IU} / \mathrm{L} ， \mathrm{r}-$ GTP $1075 \mathrm{IU} / \mathrm{L}$ と上昇し、血中 AMY

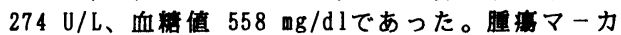

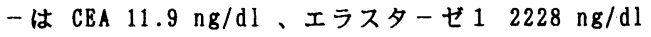

と高值であった。

超音波㭘查および腹部 C T SCAN 所見：肝内肝外胆管 は著名に拡張し、胆菜は縮し壁の肥厚と結石を衿め た。䐙腈に多数の石灰化と䐙管の拡張および䐙頭部に 径 $70 \mathrm{~mm}$ 大の壁不整な英胞を認めた。

PTCD 後の胆道造影所見：総胆管は英腫状に腫大し、 譄管の拡張と滕内結石を多数認めた。

胆汁細胞彰は CLASS 1であった。

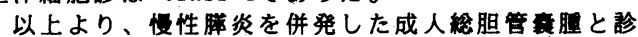
断し平成 5 年 3 月 15 日手術施行。手術所見：上腹部 正中切開にて開腹。腹水なく、胆烡及び䐙頭部を中心

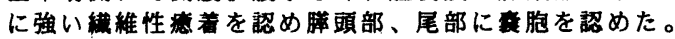
胆管を柊肝管にて切部し羘管合流部近傍にて切断した。 椫頭部の费胞を切開後、主滕管を頭部より尾部に至り 切開し、後結腈性に ROUX-en-Y 法にて、滕管空渴側 側吻合、総肝管空䐺端側吻合施行した。

病理所見：胆索に adenomyomatosis を認め、胞壁 に悪性の所見を認めなかった。

術後経過良好で、術後 1 年になる現在元気に社会復带 している。

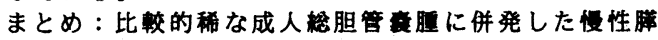
炎に対し䋓胆管切除と愺管娍圧術を施行し良好な結果 を得たので報告した。

\section{示- 80 摘出術のpitfall \\ 胆震管の合流形式からみた腹空镜下胆軎}

滋賀医科大学第一外科

来見良誠、江口 豊、花沢一芳、坪佐恭宏 岸田明博、柴田純治、小玉正智

【目的】腹腔鏡下胆喜摘出術の普及にともない術中胆 道損傷关回避することの必要性が高まり、胆囊管の合 流形式が再確笖されるよらになってきた。当科におけ る過去 11 年間の值接胆道造影定例をむとに胆䙵管の

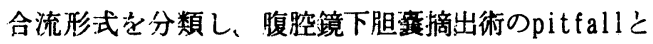
考えられる胆衰管の誤認による術中胆道損伤の回避策 について検討したので報告する。

【対象】当科批ける過去 11 年間の胆道系族患に対

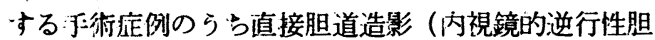
道造影、経皮経汗胆道造影、術中胆道造影)を施行し た436 例を対象に胆管の合流形式について検討し た。

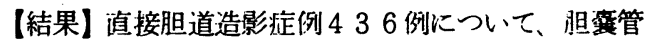
り合流形式を合流する胆管により分類した。肝内胆管 に分枝巽型がなくかつ胆罴管が総胆管に合流するタイ プ (以下C型)、肝内胆管に分枝算がなくかつ胆变 管が右串管に合流するタイプ（以下R型），右後区域 枝が左肝管汇合流しかつ胆焉管が右前区域枝に合流す るタイプ (以下A型)，右前区域枝が左肝管に合流し かつ胆霍管が右後区域枝に合流するタイプ（以下P 型）に分類した。汗闪胆管分枝異型を伴う胆蘘管合流 異常症例次計 9 例（2．1\%）に認められた。合流形 式による分類では，436例中12例（2．8\%）に 胆售管合流異常がみられ、C型424 例（97.2 $\%) 、 \mathrm{~A}$ 型 3 例 $(0.7 \%) 、 \mathrm{R}$ 型 3 例 $(0.7$ $\%) 、 P$ 型6例 (1.4\%) であった。A型、P型、 R型では総胆管に対する胆索管の合流角度が鈍角であ り、かつ胆售管と洖認し易い胆管が近傍にあるため腹

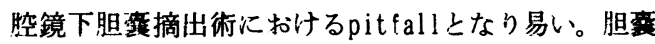

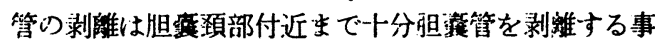
により胆震管の合流異常症洌に対する胆管損傷を回避 することが可能と考える。また、術中胆道造影は㫜衰 管合流異常祉例に対しては，胆管損傷の回避策として は不卜分である上考える。

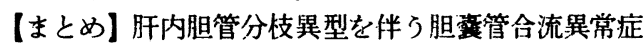
例は436 例中 9 例 $(2.1 \%)$ に喼められ心。A 型、P型、 R 型では㕵認し易い胆管が近傍にあるため 胆管損傷の原因よなり易い。牌空下胆篗摘出術におい

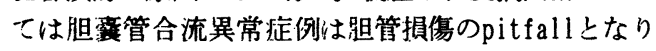
易い事より胆囊管の剥陮は胆覆預部まで十分に行い。

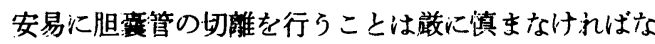
らない。 
示-81 腹腔鏡下胆衰摘出術の合併症、特に胆道 系合併症の検討

豊橋市民病院外科

鬼頭 靖、鈴木一男、千木良晴ひこ、加藤岳人、 柴田佳久、栗野、浩、岡本好史、坂口憲史、 關 知子、本野泰司、吉田克嗣、神谷 諭、 安部哲也、平松聖史

【目的】腹胿鏡下胆亳摘出術（以下 LC) において胆道 損傷などの合併症が問題となっている。当科で経験さ れた合併症、特に胆道系合併症について検討した。 【対象】1991年8月より1994年1月までにLCを301例に試 み、このうち 37 例が途中開腹胆摘 (以下OC) に移行し、 264例にLCを施行した。男性118例、女性183例で平均 年齢は 54.0 歳（13歳〜84歳）であった。総胆管結石、急 性胆震炎、上腹部手術既往例は、原則として LC の適応 外とした。LC施行例では、平均手術時間は113分 $(43$ 分〜 347分)、術後平均入院期間は 4.6 日、術中胆道造影 は、252例に行った。

【結果】(1) OC移行症例; 37例。OCに移行した理由は、 高度胆言炎等による剥離困難、又は胆表管処理不能 18 例、術中胆道造影による胆管結石疑い9例、後述の術中 合併症によるもの8例、疹着等による視野の展開不能2 例。(2)合併症; 34 例。a)術中合併症 ; 胆管切断 1 例は術 後に判明し再開腹となった。胆貫管損傷 3 例・三管合流 部胆管損稘 2 例 - 胆要動脈出血 2 例 - 小腸穿刺 1 例は $O C$ に移行した。右肝動脈の分枝損賃 1 例はLCで対処でき、 皮下気腫 1 例は保存的に軽快した。b)術後合併症 ; 心肺 合併症 8 例、胆汁瘦 6 例 (うち 1 例再開腹)、肝機能障害 5 例、遅発性胆管㹨窄2例、創感染2例、皮下血腫2例、drain 腹腔内脱落 1 例 (再開腹)、腹水 1 例が認められた。(3)胆 道系合併症は、13例にみられた。術後胆汁瘦6例中5例は 7日以内に自然治㴔、1例は、術直後よりdrainから多量 の胆汁が認められ、再開腹を要した。胆表管損賃3例・ 三管合流部胆管損稘2例は全例 OCに移行した。このう ち三管合流部胆管損稘の1例は、損傷縫合部から胆汁瘦 が生し、術後25日目に遅発性胆管狭窄が発症した。PTCS カテーテルによる拡張術を施行した。もう1例の遅発性 胆管狭窄は術中術後とも特に問題なかったが、術後 21 日目に総肝管の狭窄が発症した。同様にPTCSカテー テルによる拡張術を施行した。胆管切断の1例は、胆衰 管の誤認によるもので、術後3日目 ERCPで確認され、 再手術し肝管十二指腸吻合を施行した。

【まとめ】(1)胆道系合併症を検討するにCalot の三角の 解剖学的構造を念頭に置いて、胆甚管を愛護的に剥離 することが重要で、万一胆道損賃が疑われ、正しい修 復に確信が持てない場合は、開腹術に変更するべきで あると考えられた。(2)術中胆道造影は、胆道損賃の発 見、clipping 位置決定に有用である。(3)胆管狭窄は遅 発性に発症することがあるので注意を要する。
示 -82

腹腔鏡下手術の pitfall

一当院における術中造影の経験

東京厚生年金病院 外科○坂佳奈子, 今成朋洋, 石原聡一郎, 北崎麻美子, 望月能成, 武井芳樹, 野田泰永, 増田幸蔵, 松本政雄, 志田晴彦, 町田武久, 山本登司

我々は 1991 年 7 月から 1994 年 2 月むでに 170 例の 腹腔鏡下胆囊摘出術を施行してをた。術中胆道造影は 45例に施行し, 35例で成功した。術中造影の適応は術 前の血液検査におらて肝胆道系酵素の異常を認めるも の, 腹部超音波検查をたはDＩＣにて総胆管結石が疑 わしい症例でかつ術前にERCPが出来なかった症例に 行らことを原則としたが開始当初は手技になれるため もあり潘全例に試みた。

術中造影にて明らかな異常を認めたのは 5 例で, 総 胆管に陰影欠損があり結石が疑われた症例が 4 例, 上 部胆要が造影されず総胆管損傷が明らかとなった症例 が 1 例であった。以上 5 例のらち総胆管結石の 1 例に ついては引続き腹腔鏡下に総胆菅を切開し切石に成功 したが, 残りの 4 例については開腹手術に変更となっ た。

胆管損傷例はMirizzi 症候群で，総胆管を胆囊管と 誤認して切開しており, 開腹下に修復し。術後問題な く経過し，術中造影が有効であったと考えられる。

しかし，総胆管結石を疑い開腹に変更した 3 例のら ち2例については総胆管切開したとてろ, 明らかな結 石は存在しなかった。

1 例は51歳男性。術前に疝痛発作。黄㾝, 高アミラ 一ゼ血症を認め, 総胆管結石の存在を疑っていたが, E R C P を施行せずD I C のみで胆管に異常なしと判。 十二指腸へ排石したと考えていた。術中造影では下部 胆管に陰影欠損を認めたが，開腹所見では小さな凝血 塊を認めたのみであった。

2 例目は50歳男性。術前検査にて問題となる所見な く ERCPは施行しなかった。術中造影においてやはり 下部胆管の陰影欠損を認め開腹に変更したが, 結石は 存在しなかった。

これら 2 症例の経験より現在では。術前に総胆管結 石が疑わしい場合には必ずERCP を施行するととを原 則としている。そして, 術中造影は総胆管結石の疑い があり, 術前のERCPが不成功又はその造影が不充 分の場合に行らことを基本としている。また，胆営損 傷の予防として行ら場合もあるが, 胆管損傷に関して 岋丁掌な剥離操作により，てれを予防するように心掛 けるととが重要であると考えている。

以上術中造影により不必要に開腹に変更した 2 症例 に対する反省を中心に術中造影のありかたについて考 察を加え発表する。 
示-83腹腔鏡下胆囊摘出術における pitfall

大阪厚生年金病院外科

山崎 元、桑田圭司、山崎芳郎、橋本純平、

長岡眞希夫、山本重孝

目的 : 今や腹腔鏡下胆震摘出術 (LC)は胆石症に対する 標準術式となり、多くの施設で多数のLCが施行されて いる。当初、限られた施設で施行され既に各種合併症 が報告されているが、今後多施設での症例の増加に伴 いその合併症も増加すると考えられ、今回我々の経験 した695例のLCの成績につきその合併症とその対策に つき報告する。対象及び方法 : 1991年2月から1994年2 月までに当科でLCを施行した695例を対象とした。こ の内、総胆管結石合併例は27例(3.9\%)であり、EST併施 17例、腹腔鏡下切石10例であった。これらLC例に於け るpitfal1 と考えられる合併症につき検討を加えた。 結果 : 1. 695例中開腹移行例は23例 (3.3\%)であり、そ の理由はLC操作そのものによるもの6例 (0.9\%) [出血4 例、胆道損傷2例]、その他17例 [炎症強度11例、癒着 強度4例、総胆管結石合併 1 例、胆雯癌合併 1 例] であっ た。2. 大量出血をきたしたものは5例あり、肝床出血3 例、胆襄動脈出血2例であったが、肝床出血の1例を除 き4例が開腹移行した。肝床出血例は何れも炎症強度 例であり、1例は肝硬変を併存していた。主な理由は肝 床部の切離層が判別困難であり十分な止血操作ができ なかったことによる。胆裹動脈からの出血は1例が初 期症例の洗浄操作による止血clipの滑脱、1例が胆震動 脈深枝からの出血であり、いずれも慎重な手術操作で 回避できた可能性があった。3. 胆道損傷例は6例に認 め、2例が開腹移行となった。開腹移行例は1例が初期 症例の総胆管を胆震管之誤認し離断したものであり、1 例は肝門部の止血clipが右肝管にかかり術後黄㾝をき たしたものである。いずれもT-tubeを留置し修復し た。術中修復し得たものは4例あり、2例が肝床よりの 胆汁漏出にたいし縫合およびc1ipで、1例が胆震管総胆 管移行部損傷に対し縫合およびc-tube留置で、1例が胆 裹動脈切離の際に裹面の右肝管を損傷し縫合したが、 術後胆汁漏をきたしENBDtubeを留置し対処した。4.そ の他に術後胆衰管断端からの胆汁漏出に対しENBDtube を留置したもの、留置したドレーンの腹腔内落下に対 し腹腔鏡下に摘出したもの、保存的治療で軽快した肝 硬变併存例での術後難治性リンパ漏および術後第一病 日に発症した肺梗塞例を各々1例経験した。

結語 :LCにおけるpitfal1は開腹胆摘で経験された胆道 損傷を主とする合併症に加えて、気腹状態での内視鏡 下手術という特有の合併症が起こり得る。特に大血管 損傷、胆道損傷や腸管損傷はその診断を誤ると重篤な 結果を引き起こすことから、気腹から閉創までの全手 術操作において起こり得る合併症を常に念頭におき手 術操作を進める事が肝要と考えられた。
示-84 ${ }^{18} \mathbf{F}$-fluorodeoxyglucose PETを用いた 腫瘍糖代謝評価による消化器癌悪性度判定の検討 一食道癌を中心に一

千葉大学第二外科

岡住慎一, 榎本和夫, 福長徹, 浅野武秀, 長島通, 天野穂高, 吉田雅博, 井奥昇司, 小出義雄, 磯野可一 [目的］悪性腫瘍においては、糖代謝が方進しており、 增殖速度に相関するとされている。今回、glucose の アナログである ${ }^{18}$ F-fluorodeoxyglucose(FDG) をトレ ーサーとした、positron emission tomography(PET) により、in vivo にて消化器悪性腫瘍の糖代謝を評価 し、腫瘍糖代謝能による悪性度判定の有用性について 検討した。[対象] 消化器悪性腫瘍 149例( 食道癌70例、 肝細胞癌35例、胃癌 5 例、大腸癌 5 例、胆管細胞癌 9

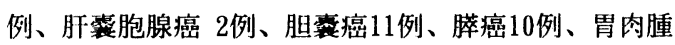
1例、回腸肉腫 1 例 )、良性腫瘍 12 例( 肝血管腫 3 例、 肝囊胞 2例、膵島細胞腫 2例、膵震胞腺腫 2例、膵 solid cystic tumor 1例、脾リンパ管腫 1例、後腹膜 平滑筋腫 1 例)。[方法] FDG4mCi (148MBq)を静注し、組 織への集積がほぼ一定となる60分後に島津ポジトロン C T 装置SET-130Iを用いて病変部の横断像を撮像し、 同時に採血を行った。画像より得られた病変部の放射 能濃度 $(\mathrm{Ci})$ と、血墏中の放射能濃度 $(\mathrm{Cp})$ の比: $\mathrm{Ci} / \mathrm{Cp}$ (60) を指標として、FDG の集積度を評価した。また、 $\mathrm{Ci} / \mathrm{Cp}_{(60)}$ と解糖系酵素hexokinase 活性との関係を、 実際に食道癌切除標本13例について検定した。[成績] 切除標本のhexokinase活性は $\mathrm{Ci} / \mathrm{Cp}_{(60)}$ ～と有意に相関 した $(\mathrm{p}<0.01)$ 。FDG-PETにて、覀性腫瘍は陽性像を示し、 $\mathrm{Ci} / \mathrm{Cp}_{(60)}$ は、食道癌5. $05 \pm 2.10$ 、肝細胞癌 $2.54 \pm 1.19$ 、 胃癌 $3.69 \pm 0.86$ 、大腸癌 $5.54 \pm 1.37$ 、胆管細胞癌 2.80 \pm 0.61 、胆襄癌 $3.28 \pm 0.94$ 、膵癌 $2.74 \pm 0.58$ 、胃肉腫 4.05 、 回腸肉腫3. 94 であり、正常周井臓器 $(\mathrm{Ci} / \mathrm{Cp}(60)<2.0)$

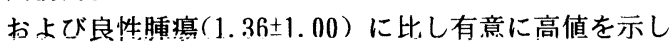
た。 $\mathrm{Ci} / \mathrm{Cp}_{(60)}$ 值と悪性度についてみると、食道癌術 後(根治度CI以上) 1 年経過例において、有再発例 $(n=$ $14)$ )原発巣の $\mathrm{Ci} / \mathrm{Cp}_{(60)}(5.21 \pm 1.39)$ は無再発例 $(\mathrm{n}=$ $17)(4.06 \pm 1.52)$ に比し有意に高値を示し $(p<0.05) 、$ 術後 3 年生存率では、 $\mathrm{Ci} / \mathrm{Cp}_{(60)}<4.0(\mathrm{n}=14)$ では $74 \%$ 、 4. $0<\mathrm{Ci} / \mathrm{Cp}_{(60)}<6.0(\mathrm{n}=13)$ では51\%、6. $0<\mathrm{Ci} / \mathrm{Cp}_{(60)}(\mathrm{n}=$ $12)$ では $12 \% て ゙ あ り 、 \mathrm{Ci} / \mathrm{Cp}_{(60)}>6.0$ 群は有意に予後不 良であった $(\mathrm{p}<0.05) 。[$ 結論]FDG-PETにて評価した消化 器覀性腫瘍の糖代謝は、良性組織よりも有意に高かっ た。食道癌の検討では、原発巣の評価により高再発群 の予測が可能と考えられ、又、予後評価にも $\mathrm{Ci} / \mathrm{Cp}$ (60) が独立した予後因子として有用と考えられた。本法は、 術前に非侵襲的かつ腫瘍部全体を評価できる点で優れ ており、さらに、 $\mathrm{Ci} / \mathrm{Cp}_{(60)}$ を指標として腫瘍糖代謝 能による悪性度の定量的判定が可能と考えられた。 